\author{
Mon ograph \\ urn:lsid:zoobank.org:pub:CC8487E0-169D-4B32-A2AB-F9B34DFB3F3B
}

\title{
Revision of the stygobiont gastropod genera Plagigeyeria Tomlin, 1930 and Travunijana Grego \& Glöer, 2019 (Mollusca; Gastropoda; Moitessieriidae and Hydrobiidae) in Hercegovina and adjacent regions
}

\author{
Jozef GREGO \\ Horná Mičiná, SK-97401 Banská Bystrica, Slovakia. \\ jozef.grego@gmail.com \\ urn:1sid:zoobank.org:author:44C83AAB-CF4E-46E8-8146-DFBADA150AB6
}

\begin{abstract}
The genus Plagigeyeria Tomlin, 1930 is one of the most typical elements representing the stygobiont fauna in the southern Dinaric Alps. In the current study I present the territory of Hercegovina (and its adjacent regions of Bjelašnica and the Dalmatian coast containing transboundary aquifers) as one of the two main biodiversity hotspots for distribution of the genus. It is comparable with the species radiation of Plagigeyeria in the Kotor Bay-Skadar Lake Basin area. My study of the karst springs and caves revealed, besides the presently known species, twelve new Plagigeyeria taxa detected in so-far uninvestigated karstic aquifers: Plagigeyeria erossi sp. nov., P. ljutaensis sp. nov., P. konjicensis sp. nov., $P$. pseudocostellina sp. nov., $P$. reischuetzorum sp. nov., $P$. olsavskyi sp. nov., $P$. listicaensis sp. nov., P. ozimeci sp. nov., P. jakabi sp. nov., P. angyaldorkae sp. nov., P. vriosticaensis sp. nov. and P. lewarnei sp. nov. Closer shell morphology investigation supported by the protoconch morphology revealed a presence of another genus within the former Plagigeyeria complex. The following taxa are transferred herein to Travunijana Glöer \& Grego, 2019: Plagigeyeria robusta Schütt, 1959, P. robusta asculpta Schütt, 1972, P. ovalis Kuščer, 1933, P. edlaueri Schütt, 1961, P. klemmi Schütt, 1961, P. nitida Schütt, 1963, P. angelovi Schütt, 1972 and P. tribunicae Schütt, 1963, plus a new species, Travunijana gloeri sp. nov., is described for the genus. Distribution maps of both genera, Plagigeyeria and Travunijana, over the karst aquifers of Hercegovina and adjacent regions are presented with respect to the hydrogeological separation of the known spring karst conduits and aquifers.
\end{abstract}

Keywords. Cave, spring, karst, Bosnia, Neretva.

Grego J. 2020. Revision of the stygobiont gastropod genera Plagigeyeria Tomlin, 1930 and Travunijana Grego \& Glöer, 2019 (Mollusca; Gastropoda; Moitessieriidae and Hydrobiidae) in Hercegovina and adjacent regions. European Journal of Taxonomy 691: 1-56. https://doi.org/10.5852/ejt.2020.691

\section{Introduction}

The Dinaric Alps (or Dinarides) mountain range with 60000 square kilometres of karst and its whole length of $645 \mathrm{~km}$ frames the eastern Adriatic coast of the Western Balkan Peninsula. The mountain range is well known for its strongly developed karstic underground aquifers being formed inside the extraordinarily large Mesozoic-Cenozoic limestone formations. The numerous geomorphologically closed basins named "Karst Poljes" are hydrogeologically characterised by occasional flooding by 
their own springs (vrelo or vrilo) and estavelles, and with their own swallow-hole (ponor) system draining each basin (Bonacci 2014; Stumberger et al. 2014). Poljes are, according to their elevation, cascade-wise interconnected by a dense web of subterranean phreatic cavities and conduits emerging in a number of springs and surface streams, representing a rather complicated hydrogeological and speleobiological scenario. The largest subterranean hydrological aquifers of the Dinarides are more or less well defined (Stevanović et al. 2014; Milanović 2018). This same hydrological scenario typical for the Dinarides can be found also in the historical western part of the region of Hercegovina (currently within the country of Bosnia and Hercegovina) (Fig. 1), where the numerous karst conduits are drained by the spectacular canyon and basin of the Neretva River, and its tributaries of the Trebižat, Bregava, Rama, Radobolja, Lištica, Ljuta, Buna and Bunica Rivers and by a small, though variable, part of the Trebišnjica River Basin. The lower part of the Neretva valley is typical of aquifers based on large alluvial gravel deposits, here forming a remarkable hyporheic zone of the karstic Neretva Delta and containing several lakes along the concentrated spring zones of Hutovo (Svitavsko) Blato, Deranjsko Jezero near Svitava, Peračko Blato and Baćinska Jezera near Ploče in Croatia. The karst aquifers of Dianaride Mountains host a remarkable stygobiont diversity (Sket 2012) and its Mollusca represent according to my estimates more than one third of the worldwide fauna. Mollusca had been a subject of intensive research especially during the last decade (Beran et al. 2014, 2016; Bilandžija et al. 2013; Boeters et al. 2013; Cindrić \& Slapnik 2012; Glöer \& Pešić 2014; Glöer \& Grego 2015; Glöer et al. 2015; Grego et al. 2018; Pešić \& Glöer 2012, 2013a, 2013b; Reischütz et al. 2013, 2014. 2016; Rysiewska et al. 2017)

To understand the stygobiont zoogeography of the Dinarides including Hercegovina, it is essential to study the hydrogeology of the area and to identify the boundaries of each of the River Basins, their main subterranean karst conduit-aquifers and their dominant water courses, which in turn may suggest their level of hydrological isolation from adjacent aquifers (Stevanović et al. 2014) (Fig.1). The species of Plagigeyeria most likely inhabit suitable hypogean habitats within the phreatic cave aquifers (karst conduit-aquifers). Unfortunately, only a comparatively small number of subterranean localities are directly accessible by an open cave system and in most cases, only empty shells can be found accumulated in the springs at the lowest drainage point of each aquifer, or deposited shells can be found also throughout the aluvial sediments. According to the condition of the shells and their fragments accumulated at the spring through recent thanatocoenosis, I assume that the habitats of Plagigeyeria could be rather distant from the spring zone inside the open cave. This is the main reason why finds the living specimens of Plagigeyeria are extremely rare and only the anatomy of a single species P. montenegrina was hitherto described (Bole 1970) from Obodska Pećina cave. However, Radoman (1983) noted its extraordinary resemblance to the anatomy of Saxurinator sketi (Bole, 1960), yet the uncertainty in the close taxonomical and anatomical relations of Plagigeyeria, Saxurinator Schütt, 1960 and Lanzaia Brusina, 1906 remains unconfirmed due to the absence of live specimens from the type localities. While the general shell morphology of Lanzaia with thin fragile elongated shells, inflated whorls and a more flaring sinular part of the aperture is quite differentiated from the general morphology of Plagigeyeria, their protoconch and shell surface sculpture is almost identical. Some Dinaric representatives of Saxurinator (e.g., S. brandti (Schütt, 1963)) has almost identical protococncch sculpture and are morphologically resemble the elongated Plagigeyeria species much more than the type species of Saxurinator (S. buresi (A. J. Wagner, 1928)). No molecular data of Plagigeyeria are available so far. Current molecular studies of the conchologically similar genera Lanzaia and Costellina Kuščer, 1933 (Hofman et al. 2018) and Dalmatian representatives of Saxurinator (Grego et al. 2019) revealed their position close to the genus Paladilhiopsis Pavlović, 1913 and in the family Moitessieriidae Bourguignat, 1863. Due to the above mentioned identical anatomical and shell morphology features I treat herein Plagigeyeria as a member of family Moitessieriidae Bourguignat, 1863. Future molecular studies will be needed to confirm this position. With respect to the extreme scarcity of live specimens of Plagigeyeria, it is not likely that enough live specimens of all species 
will be found in the near future to carry out a sufficient anatomical and molecular study for the molecular revision of the genus. Additionally, due to anthropogene influences such as hydroelectric powerplants and dam constructions, many localities are disappearing or hydrologically altering, in combination with an increasing number of groundwater pollution sources around the ponors in the poljes. For the above reason, I decided to establish herein the new taxa based on the shell morphology characters as being the only hitherto available data. I am also aware that the intraspecific variability mixed with interspecific morphological convergence could be misleading in the application of an approach based solely on shell morphology. Nevertheless it is important to bring the diversity of the genera and its localities to the focus of malacologists and environmentalists. The alternative approach of waiting for the collection of enough live specimens does not look to be productive from a long term perspective. In the case of single molecular data availability in the future, the taxonomical position of related taxa can then be revised.

Our previous knowledge about the presence of the genus Plagigeyeria in the springs (vrelo) of Hercegovina is based on the studies of A. J. Wagner (1914, 1928), Kuščer (1933), Schütt (1959, 1961, 1963, 1972, 2000) and Hirschfelder (2018) where the following twelve taxa had been recognised: P. plagiostoma (A. J. Wagner, 1914) and P. inflata (A. J. Wagner, 1928) from Vrelo "Bosna" near Ilidža; P. mostarensis Kuščer, 1933 and $P$. ovalis Kuščer, 1933 from the Vrelo "Buna" near Blagaj and from Vrelo "Bunica" near Hodbina; P. robusta Schütt, 1959 from the springs "Trebišnjica" and "Čepo" near Bileća; P. robusta asculpta Schütt, 1972 from Vrelo "Ombla" near Komolac and Vrelo "Mlin" at Mali Zaton; P. edlaueri Schütt, 1961 from Vrelo "Sopot Mlin" and another at Sjekoše on the side of the Hutovo (Svitavsko) Blato depression and Vrelo "Glušči" near Metković; P. klemmi Schütt, 1961 from Vrelo "Stenjevac" and Vrelo "Baja" near Vrgorac, the Vrelo "Kutac" and other springs around the Baćinska Lakes; P. tribunicae Schütt, 1963 from Vrelo "Trebišnjica" in Bileća; P. nitida Schütt, 1963 from Vrelo "Sopot Mlin" and other springs near Sjekoše and Bajovci at Hutovo Blato; P. angelovi Schütt, 1972 from Vrelo "Ombla" in Komolac (Schütt 1972, Schütt 2000) and P. zetatridyma Schütt, 1960 from springs in Bileća.

There are two neighbouring biodiversity hotspots for the distribution of Plagigeyeria: Hercegovina with adjacent territories (presented in this study) and the region of Kotor Bay with the whole tributary of the Skadar Lake in Montenegro and north Albania. Most of the Plagigeyeria species recognised outside the two hotspots most likely do not belong to the genus. The Caucasus stygobiont population named "Geyeria" or Plagigeyeria having a high diversity of so-far unrecognised species in Georgia, has in fact nothing in common, even in the shell morphology, with Plagigeyeria and represents a geographically isolated new genus (Grego et al. in press). Most likely the same is true for the representative of the genus from France ( $P$. deformata (Nicolas, 1891) with the junior synonym Plagigeyeria conilis (Boeters, 1974)), which was provisionally assigned to the genus only due to the resemblance of the shell aperture shape without anatomical data and zoogeographical links. It most probably also belongs to a different genus other than Plagigeyeria. The two species recorded from southeast Prokletije Mountains in Albania (Plagigeyeria steffeki Grego et al., 2017 from Krumë) and from Kosovo (P. gladilini Kuščer, 1937 from Drin i Bardhë spring near Peja), as well as one species from Bulgaria (P. procerula Angelov, 1965 from Opizvet), most likely belong to another unrecognised and geographically isolated genus. Two species of Plagigeyeria from western Serbia found close to the border with Bosnia (P. minuta Bole \& Velkovrh, 1987; P. piroti Bole \& Velkovrh, 1987) and P. jalzici Cindrić \& Slapnik, 2019 from Rudnica Cave in Croatia are also located outside the two hotspots, as is the species $P$. necopinata A. Reischütz, SteinerReischütz \& P. L. Reischütz, 2018 from south Albania; their position within the genus Plagigeyeria is still uncertain. Also, the shell morphology of species of Plagigeyeria from both southwest Dinarid hotspots is inconsistent, and in reality represent two distinct genera separated herein.

The genus Travunijana Grego \& Glöer, 2019 was just recently described from the springs Goricki Studenac and Vruljak 3, Vruljak 1 in Gorica near Trebinje. It is distinguished from all the species of 
Hydrobiidae by the morphology of the male genitals. The species appears to be a crenobiont, but it is a white animal, has reduced eyes and, except for the spring zone, it seems not to be inhabiting the adjacent Vrelo Vruljak cave system, where the Travunijana robusta (Schütt, 1959) comb. nov. is more abundant (Gergely Balázs pers. com.). So far not much is known about the taxonomic relations of Travunijana, a genus which is under investigation.

Fig. 1 (next page). Studied localities of Plagigeyeria and Travunijana in Hercegovina and phreatic hydrology of the related karstic aquifers with flow directions of the groundwater. Hydrological situation after Stevanović et al. 2014. 1-14. Newly studied localities (red dot •). 1. Konjic, spring Ljuta (LT of Plagigeyeria ljutaensis sp. nov.). 2. Konjic spring at left side of Ljuta stream (LT of P. konjicensis sp. nov.). 3. Donja Jablanica, Komadinovo Vrelo (LT of $P$. erossi sp. nov.). 4. Široki Brijeg, spring Lištica, Bilo Vrilo (LT of P. listicaensis sp. nov.). 5. Studencí, spring Kajtazovina (LT of P. olsavskyi sp. nov.). 6. Studencí, Vrilo Guljevina (LT of P. jakabi sp. nov.). 7. Donji Proboj near Ljubuški, spring Mali Prokop ( $P$. olsavskyi sp. nov.). 8. Vitina, spring Vrioštica (LT of P. vriosticaensis sp. nov. and P. ozimeci sp. nov.). 9. Lukende, Jakšenica spring (LT of $P$. angyaldorkae sp. nov.). 10. Studenci, spring Vakuf (P. cf. jakabi). 11. Dabarsko Polje, spring Vrijeka (LT of P. reischuetzorum sp. nov. and Travunijana gloeri sp. nov.). 12. Trebinje, spring Tučevac (T. robusta, Schütt, 1959 and $P$. cf. lewarnei sp. nov.). 13. Trebinje, Gorica, spring Vruljak (T. robusta and LT of P. lewarnei sp. nov.). 14. Vučija, Sušićka Jama Estavelle (P. lewarnei sp. nov.). 15-32. Historical localities (blue dot •): 15. Blagaj, spring of Buna (P. mostarensis var. Kuščer, 1933 and LT of $P$. pseudocostellina sp. nov.). 16. Hodbina, spring of Bunica (P. mostarensis Kuščer, 1933 and Travunijana ovalis (Kuščer, 1933)). 17. Bileća, spring Trebišnjica (T. robusta (Schütt, 1959) and T. tribunicae (Schütt, 1953)). 18. Čepelica, spring Čepo (T. robusta (Schütt, 1959)). 19. Bileća, spring Miruše (T. robusta (Schütt, 1959) and T. tribunicae (Schütt, 1953), P. zetatridyma Schütt, 1959). 20. Bileća, spring Dobriševo (T. robusta, (Schütt, 1959)). 21. Fatničko Polje, Obod Cave (T. robusta (Schütt, 1959), P. reischuetzorum sp. nov., T. gloeri sp. nov.). 22. Gacko, Cave Stepen (T. robusta). 23. Mlini, spring south of Plat (T. robusta asculpta Schütt, 1972). 24. Komolac, spring Ombla (T. robusta asculpta Schütt, 1972 and T. angelovi Schütt, 1972,). 25. Mali Zaton, spring Mlin (T. robusta asculpta (Schütt, 1972), T. angelovi (Schütt, 197)). 26. Svitavsko Blato, spring Sjekoše (T. edlaueri (Schütt, 1961), T. nitida (Schütt, 1963)). 27. Svitavsko Blato, spring Sopot Mlin (T. edlaueri (Schütt, 1961), T. nitida (Schütt 1963)). 28. Svitavsko Blato, spring Bajovci (T. edlaueri (Schütt, 1961)). 29. Metković, spring Glušči (T. edlaueri and T. nitida (Schütt, 1963)). 30. Ploče, spring Ocuša at bank of Bačinsko Jezero Lake (T. klemmi (Schütt, 1961)). 31. Vrgorac, spring Stenjevac (T. klemmi (Schütt, 1961)). 32. Ilidža, Vrelo Bosne (P. plagiostoma (A. J. Wagner, 1914) and P. inflata (A. J. Wagner, 1928)). 1-43. Karst basins - Poljes of the studied region (green square $\mathbf{m})$ : 1. Konavosko Polje, $50 \mathrm{~m}$ a.s.l. 2. Zubačko Polje, $672 \mathrm{~m}$ a.s.1. 3. Konjsko and Carevo P., 829-875 m a.s.l. 4. Mokro Polje, (Popovo Polje) $269 \mathrm{~m}$ a.s.l. 5. Popovo Polje, $227 \mathrm{~m}$ a.s.l. 6. Jasen Polje, $556 \mathrm{~m}$ a.s.l. 7. Ljubomirsko Polje, $506 \mathrm{~m}$ a.s.l. 8. Ljubinjsko Polje, $396 \mathrm{~m}$ a.s.l. 9. Plansko Polje, $609 \mathrm{~m}$ a.s.l. 10. Fatničko Polje, $452 \mathrm{~m}$ a.s.l. 11. Dabarsko Polje, $472 \mathrm{~m}$ a.s.l. 12. Lukavačko Polje, $895 \mathrm{~m}$ a.s.l. 13. Slato Polje, $1012 \mathrm{~m}$ a.s.1. 14. Cerničko Polje, $816 \mathrm{~m}$ a.s.l. 15. Gatačko Polje, $936 \mathrm{~m}$ a.s.l. 16. Nevesinjsko Polje, $817 \mathrm{~m}$ a.s.l. 17. Trusinsko Polje, $866 \mathrm{~m}$ a.s.l. 18. Stolačko Polje, $45 \mathrm{~m}$ a.s.l. 19. Rotimlja Polje, $422 \mathrm{~m}$ a.s.l. 20. Crničko Polje, 212 m a.s.l. 21. Hutovo Blato, 2 m a.s.l. 22. Svitavsko Blato, 2 m a.s.l. 23. Gradac Polje, $88 \mathrm{~m}$ a.s.1. 24. Vrgorsko (Jezerac) Polje, $20 \mathrm{~m}$ a.s.l. 25. Rastok Polje, $72 \mathrm{~m}$ a.s.1. 26. Ljubuško Polje, 58 m a.s.1. 27. Studeničko Polje, $25 \mathrm{~m}$ a.s.l. 28. Čitluško Polje, $217 \mathrm{~m}$ a.s.l. 29. Mostarsko Blato, $223 \mathrm{~m}$ a.s.l. 30. Mokro Polje, $230 \mathrm{~m}$ a.s.l. 31. Rašanjsko Polje, $344 \mathrm{~m}$ a.s.l. 32. Kočerinsko Polje, $302 \mathrm{~m}$ a.s.l. 33. Imotsko \& Grudsko P., 251-280 m a.s.1. 34. Posuško Polje, $578 \mathrm{~m}$ a.s.l. 35. Dugo (Dugorudo) Polje, 1206 m a.s.l. 36. Ravanjsko Polje, 1131 m a.s.l.; 37. Rakitno Polje, $890 \mathrm{~m}$ a.s.l. 38. Vučipolje, 977 m a.s.l.; 39. Roško Polje, 894 m a.s.l. 40. Duvanjsko Polje, 865 m a.s.l. 41. Džepi Polje, 830 m a.s.l. 42. Prečko Polje, $1002 \mathrm{~m}$ a.s.1. 43. Hansko Polje, $835 \mathrm{~m}$ a.s.1. 44. Donje Ziemlje, $507 \mathrm{~m}$ a.s.l. 


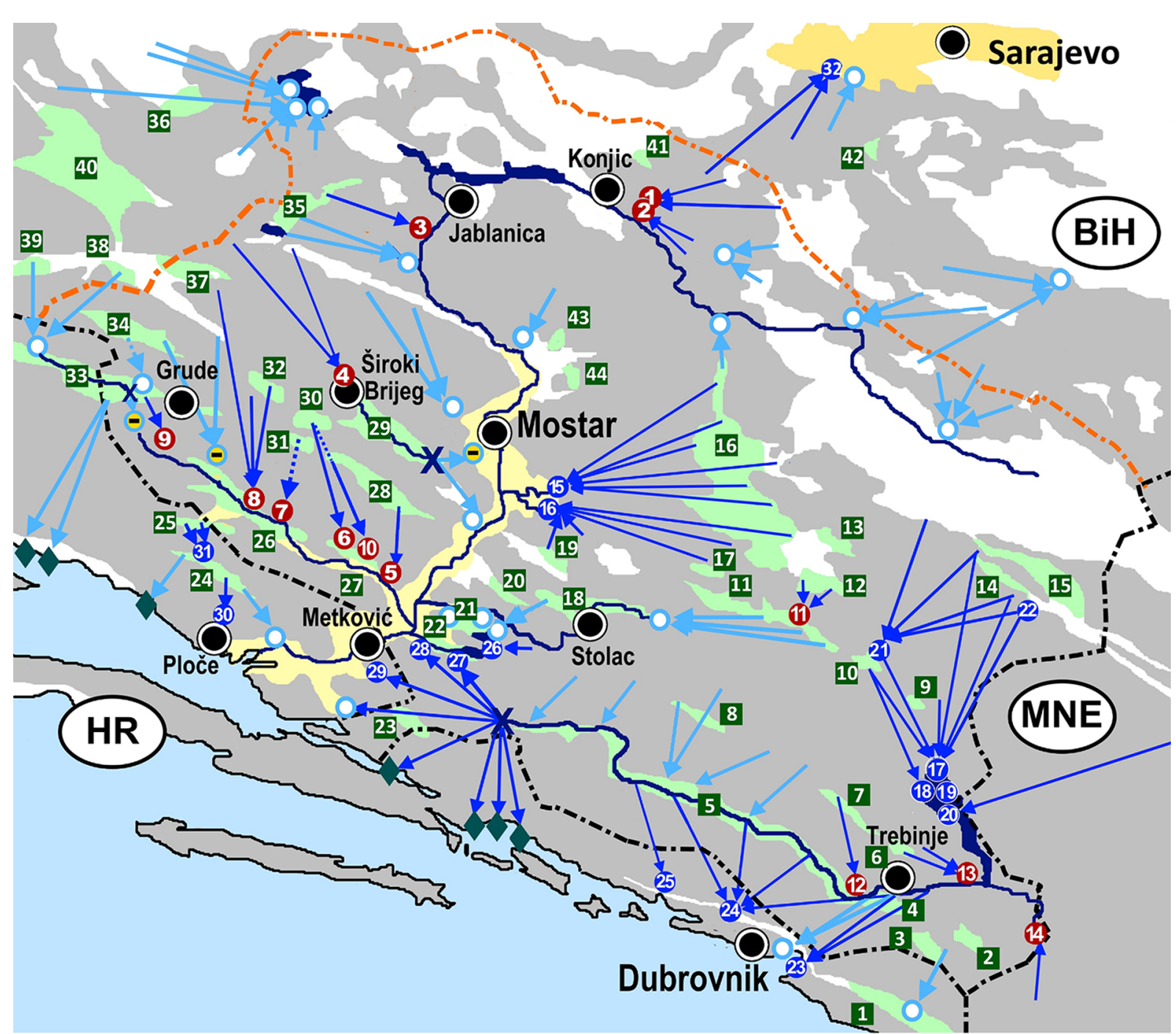

\section{LEGEND:}

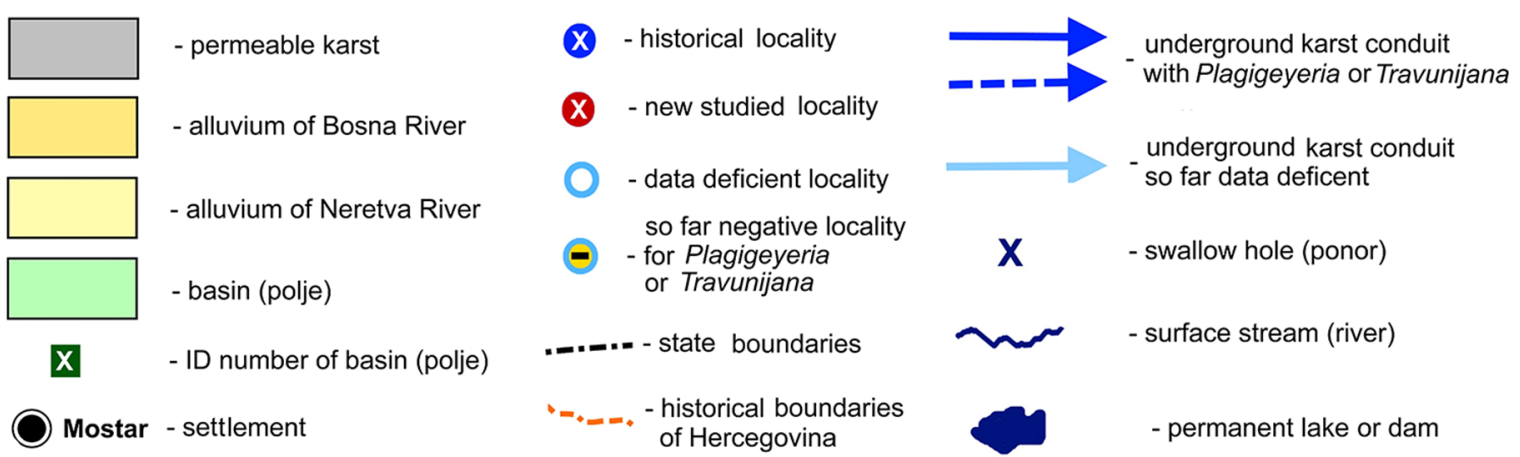

Due to the permanent lack of live material collected as well as the very scarce, empty and eroded shell material from spring sediments, the genus Plagigeyeria has not been studied at all since the time of Hartwig Schütt (last publications 1959-1972) and thus the species complex was very poorly understood. The present study introduces more light into this mysterious species complex from very obscure habitats, whilst pointing out its inhomogeneity at the genus level, as well as its high morphotype diversity over the studied area. 


\section{Material and methods}

The studied material was collected during field trips in Hercegovina and Montenegro in the years 2015-2019 (Fig. 1). Various karstic spring outflows were sampled (Figs 1-4). Microhabitat preference and sampling methods were selected and used as described by Grego et al. 2017. Samples of fine sand were freshly wet-screened under a stereo microscope for live animals. Then the samples were dried and screened again for shells that might have been overlooked during the wet-screening. Frontal, ventral and lateral view images of the shells were made by a Nikon SMZ25 microscope with a Nikon D200 camera and an AF-S Micro NIKKOR $60 \mathrm{~mm}$ lens at the Vienna Natural History Museum (NHMW), Austria. ImageJ scientific image analysing software was used to take the measurements of the specimens.

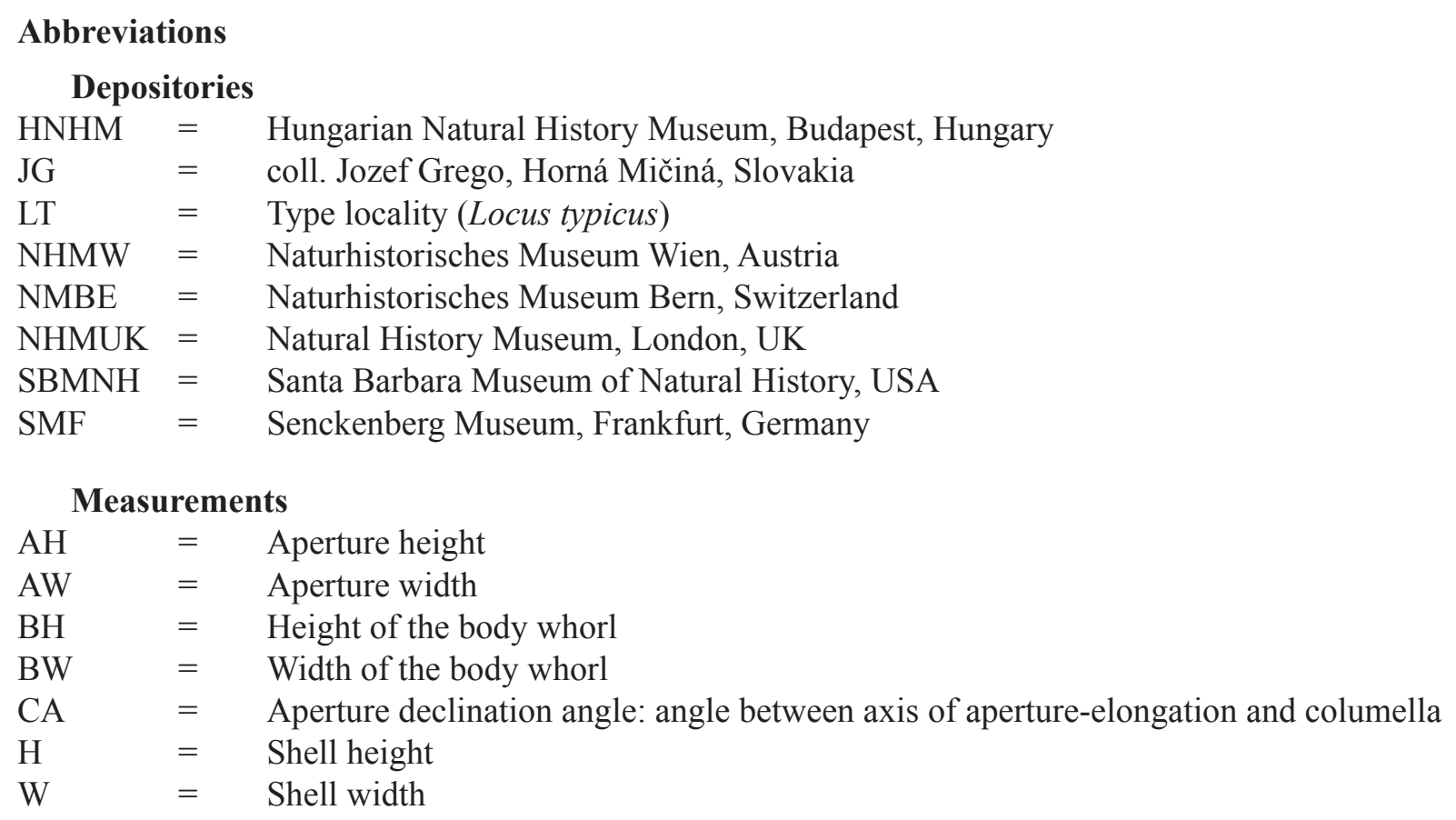

\section{Results}

Class Gastropoda Cuvier, 1795

Clade Littorinimorpha Golikov \& Starobogatov, 1975

Superfamily Truncatelloidea J.E. Gray, 1840

Family Moitessieriidae Bourguignat, 1863

Subfamily Belgrandiellinae Radoman, 1983

Genus Plagigeyeria Tomlin, 1930

Type species: Geyeria plagiostoma A. J. Wagner, 1914

\section{Diagnosis}

The genus is represented by solid shells with rather thick walls and expanded, outward reflexed labrum with mostly sinuated lateral profile and sinuated columellar margin, by teleoconch surface covered with weaker or coarser, sometimes sinuated regular axial ribs diagonally cross-connected by weaker or coarser crenate spiral lamellae, by cancellated nepionic whorl covered by fine, very close-set axial riblets cross-sected with closely set spiral ribs, by protoconch surface covered by fine irregularly crenated spiral riblets with crenated or malleated inter-rib spaces and malleated nucleus. 


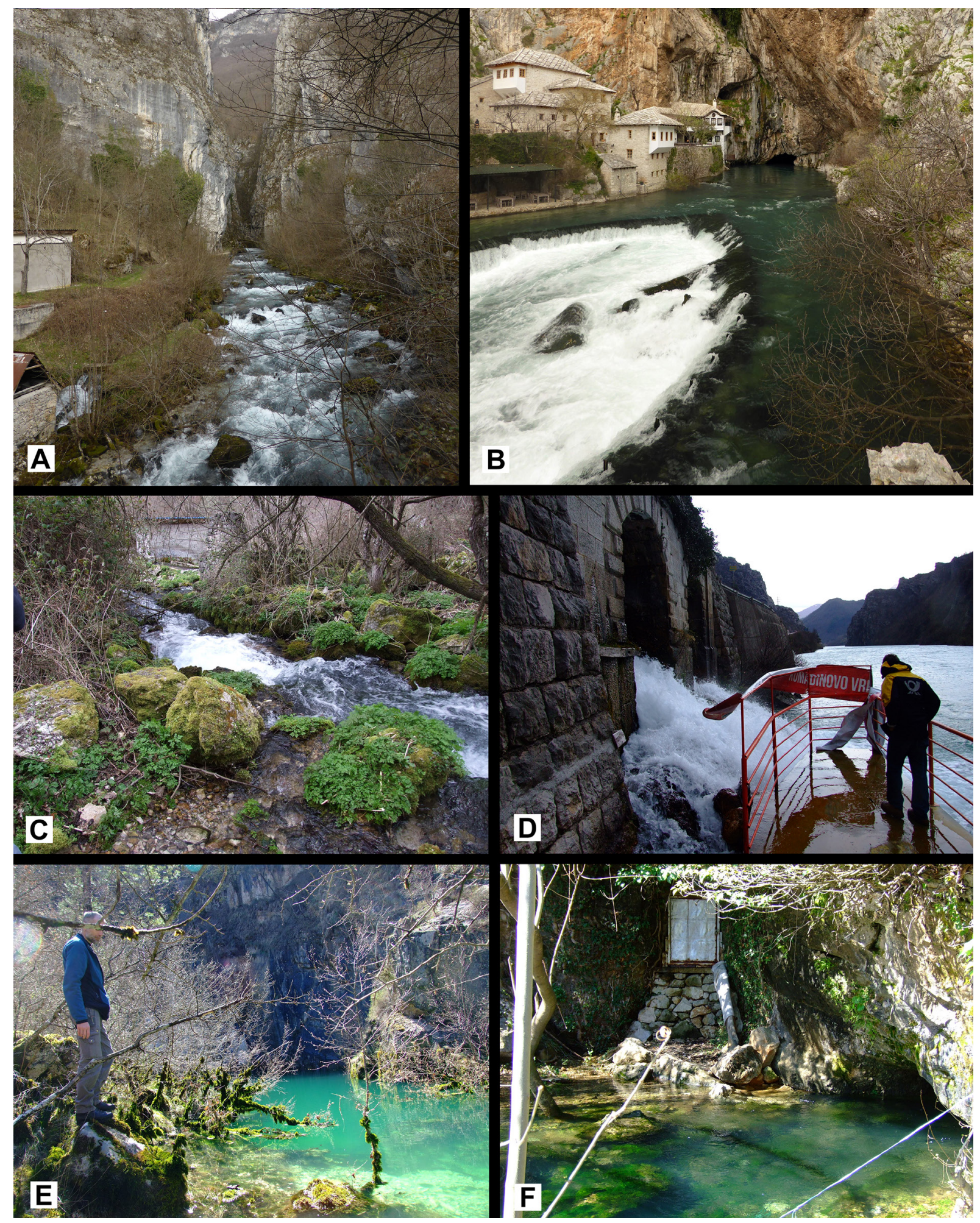

Fig. 2. Photos of studied localities in Hercegovina. A. Konjic. Ljuta spring (LT of Plagigeyeria ljutaensis sp. nov.). B. Blagaj, spring Buna (P. mostarensis var.). C. Konjic, spring at left bank of Ljuta Rivulet (LT of $P$. konjicensis sp. nov.). D. Donja Jablanica, Komadinovo Vrelo (LT of P. erossi sp. nov.). E. Vučija, Sušicka Jama ( $P$. cf. lewarnei sp. nov.). F. Trebinje, Gorica, spring Vruljak 1 ( $P$. robusta and $P$. lewarnei sp. nov.). Photos: Jozef Grego, Dorottya Angyal and Mário Olšavský. 


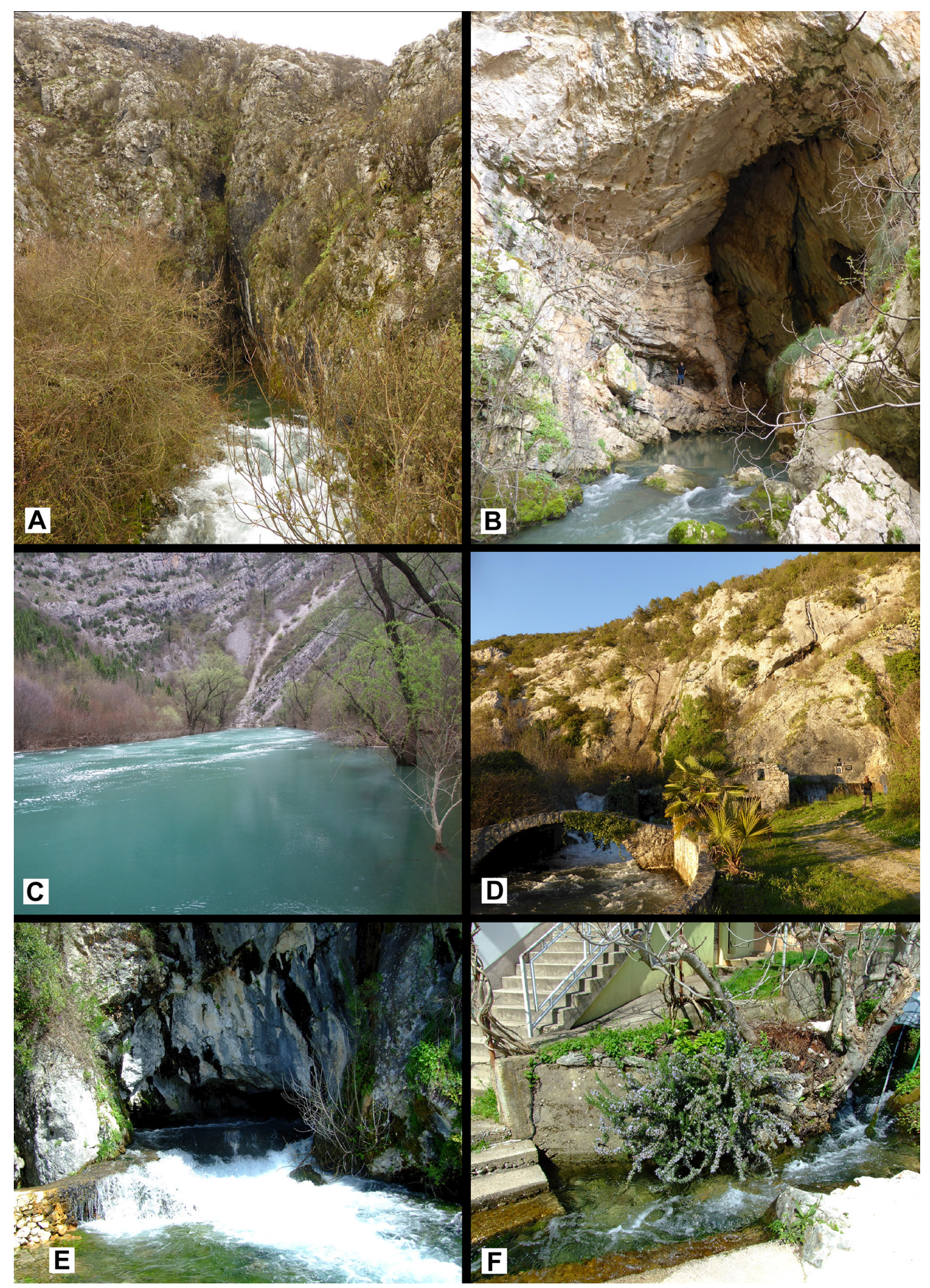

Fig. 3. Photos of studied localities in Hercegovina. A. Dabarsko Polje, Sušicka Peć cave near spring Vrijeka (LT of Plagigeyeria reischuetzorum sp. nov. and Travunijana gloeri sp. nov.). B. Tihaljina, spring Tihaljina in Peć Mlini Cave (Belgrandia torifera Schütt, 1961). C. Hodbina, spring Bunica (likely LT of $P$. mostarensis Kuščer, 1933, $P$. ovalis Kuščer, 1933). D. Studenci, spring Kajtazovina (LT of $P$. olsavskyi sp. nov.) E. Vitina, spring Vrioštica (LT of P. vriosticaensis sp. nov. and P. ozimeci sp. nov.) F. Lukende, Jakšenica, Vrelo Jakšenica (LT of P. angyaldorkae sp. nov.) Photos: Jozef Grego, Dorottya Angyal and Mário Olšavský. 

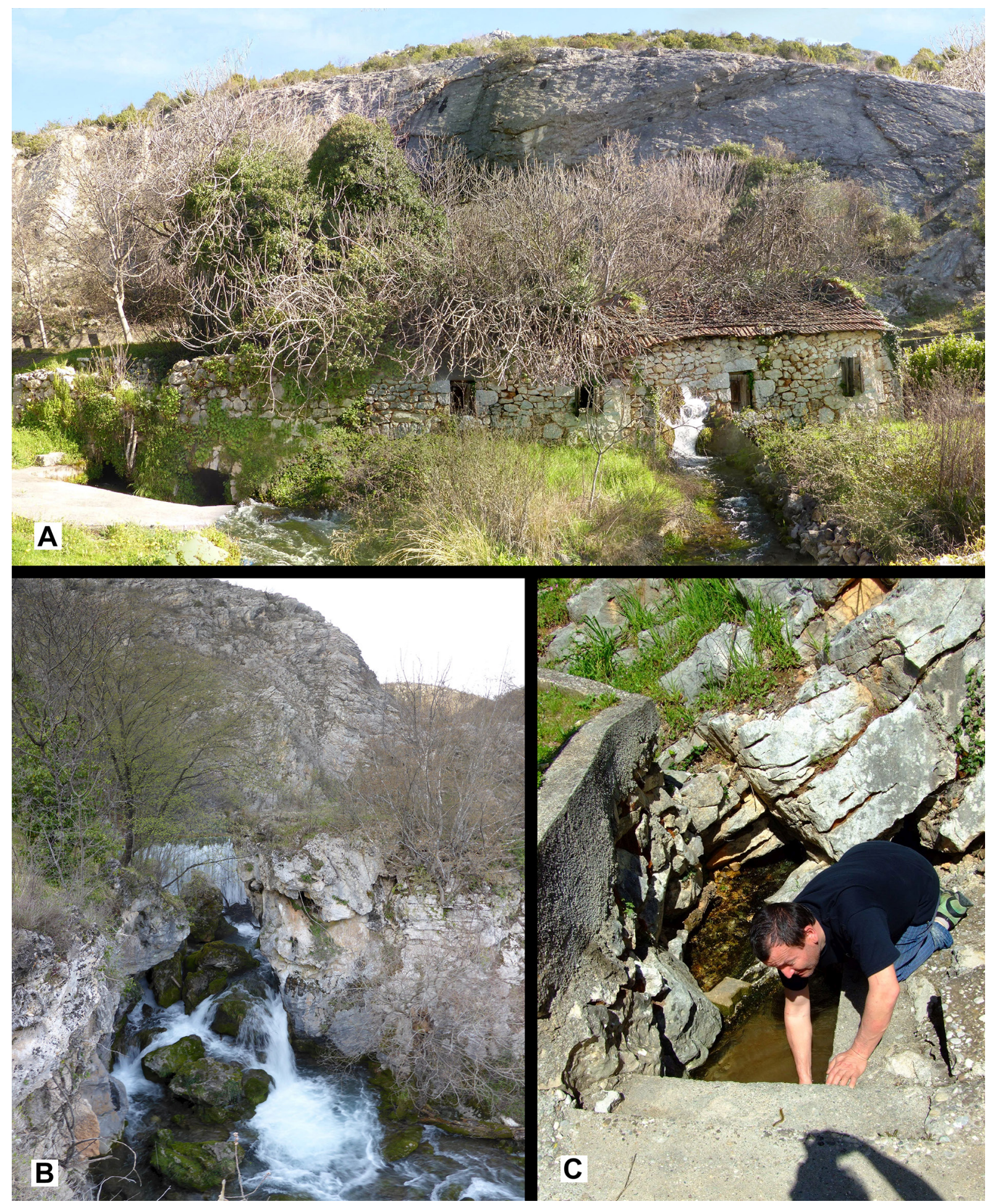

Fig. 4. Photos of studied localities in Hercegovina. A. Studenci, Vrilo Guljevina (LT of Plagigeyeria jakabi sp. nov.). B. Široki Brijeg, Bijelo Vrelo - Lištica 2 (LT of P. listicaensis sp. nov.) C. Donji Prolog, spring Mali Prokop (P. olsavskyi sp. nov.). Photos: Jozef Grego, Dorottya Angyal and Mário Olšavský. 


\section{Anatomy}

The anatomy of Plagigeyeria montenegrina Bole, 1961 from Obodska Pećina, Rijeka Crnojevića, Montenegro was described by Bole 1970 (p. 105-106, fig. 7C).

\section{Distribution}

The distribution of Plagigeyeria in the studied area represents a hotspot within the Neretva and South Bosnia River drainage basins ranging from Ilidža near Sarajevo southwards to Mostar, Tihaljina and Trebinje (Fig. 18). The closest adjacent distribution of the genus represents a second distribution hotspot at the basin of river Zeta, Kotor Bay and Skadar Lake Basin (as a part of Drin River drainage basin). A third smaller distribution area is isolated in northwest Kosovo (Peja) and Northeast Albania (Krumë) in the Drin drainage basin. Single species are known from, west and east Serbia, Bulgaria, as well as from South Albania. The single species from France likely represents a different genus, as well as the two species from Western Greater Caucasus assigned to Plagigeyeria (Starobogatov 1962), which belong to a different unrelated new genus (Grego et al. in press).

\section{Remarks}

The current understanding of the genus gathers many similar morphotypes from a very wide geographical range from France to southwestern Caucasus. Herein we focus on the species of Plagigeyeria from the studied area only, sharing the general shell morphology features with the type species so their assignment to the genus is convincing.

Plagigeyeria plagiostoma (A. J. Wagner, 1914)

Figs 5A, 6C

Geyeria plagiostoma A. J. Wagner, 1914: 123 (1): 46-47.

Plagigeyeria plagiostoma - Tomlin, 1930: 24.

Geyeria plagiostoma - A. J. Wagner 1928: 285, pl. 13. figs 70, 71, 73.

Plagiogeyeria (sic) plagiostoma - Kuščer 1933: 62.

Plagigeyeria plagiostoma - Jaeckel, Klemm \& Meise 1957: 174. — Jaeckel 1967: 92. — Schütt 1972:

114, 119, pl. 6. fig. 1. - Willmann \& Pieper 1978: 126. — Radoman 1983: 107, 224, pl. VII. fig. 21 (p. 225). — Bole \& Velkovrh 1986: 202. — Bodon, Manganelli \& Giusti 1996: 33, fig. 13. — Bank 2013: Fauna Europaea v. 2.6. - Bank \& Neubert 2017: 25.

\section{Diagnosis}

Rather small shell (1.9 mm high) with faintly axially ribbed teleoconch, cancellate nepionic whorl and spirally ribbed protoconch with smoothly malleated nucleus, with open umbilicus, oval elongate, slightly expanded aperture.

Fig. 5 (next page). A. Plagigeyeria plagiostoma (A. J. Wagner, 1914), from Vrelo Bosne in Ilidža, (topotype JG F1116). B. Travunijana vruljakensis Grego \& Glöer, 2019, Gorica near Trebinje, spring Studenac (holotype HNHM-MOLL-104416). C. P. inflata (A. J. Wagner, 1928), from Vrelo Bosne in Ilidža (topotype JG F1117). D. P. ljutaensis sp. nov., Konjic district, spring of River Ljuta (holotype HNHM-MOLL-104180). E. P. konjicensis sp. nov., small spring at left bank of Ljuta River, $600 \mathrm{~m}$ downstream of the main spring (holotype HNHM-MOLL-104174); F-G. P. olsavskyi sp. nov., Studenci, spring Kajtazovina F. Holotype (HNHM-MOLL-104178). G. Paratype (JG F1192). H-I. P. olsavskyi sp. nov., Ljubuški district, Donji Proložac, spring Mali Prokop (JG F1209). 


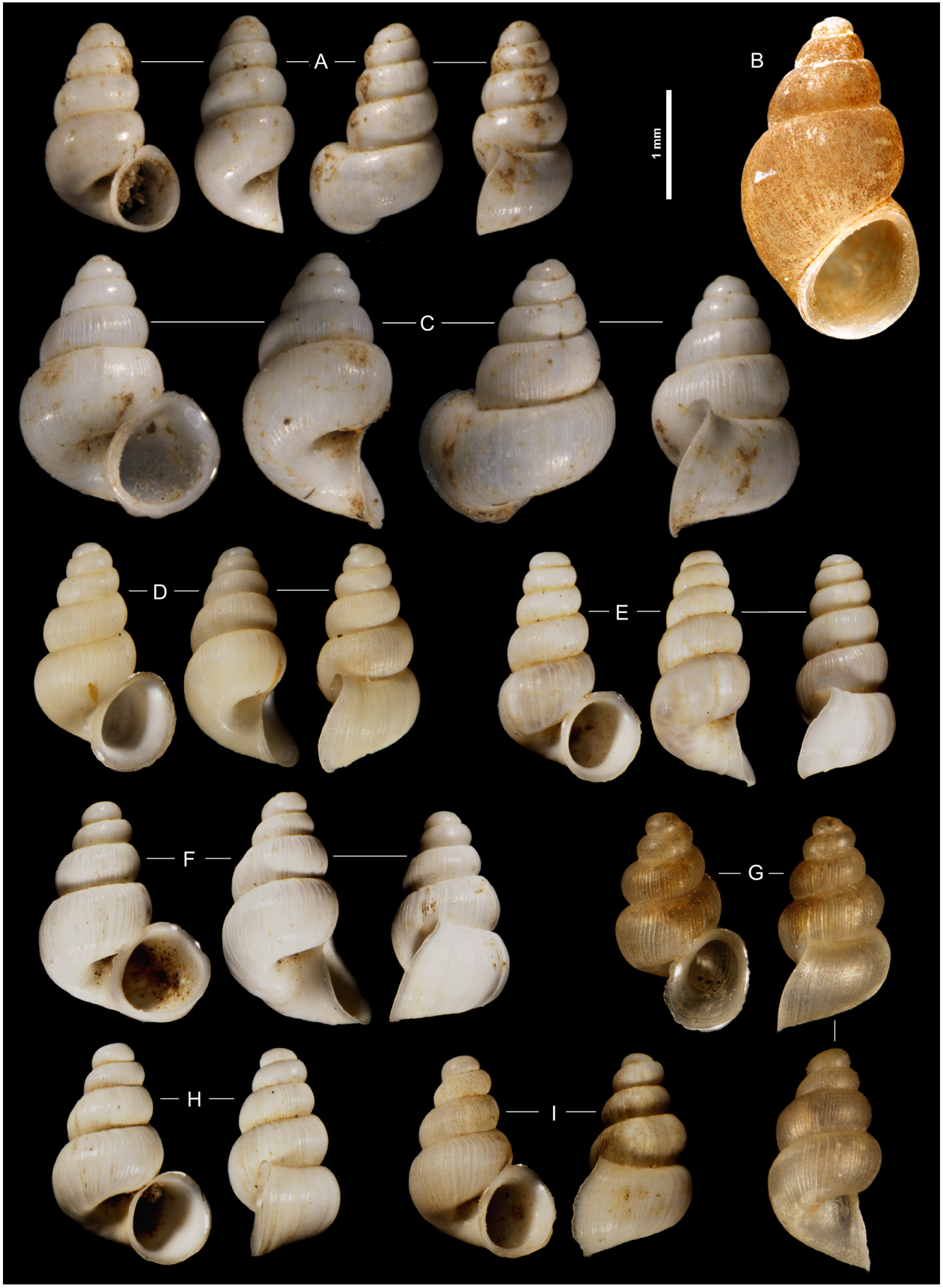




\section{Distribution}

The species is known only from the spring of Bosna River (Vrelo Bosne) (581 m a.s.1.) near Ilidža, south of Sarajevo. This spring is draining the karst waters of the Igman Massif (1502 m a.s.l) and North Bjelašnica Massif (2067 m a.s.1.).

\section{Remarks}

The type species of the genus, Plagigeyeria plagiostoma, with P. inflata, were both originally described from the Bosna River Springs in Ilidža under the genus "Geyeria", named after the famous German malacologist David Geyer (6 November 1855-6 November 1932). However the genus name was invalid due to homonymy, as it had been previously used by Buchecker in 1876 to name a moth in the family Castniidae Boisduval, 1828, by Buckman in 1899 for a cephalopod, by Carapezzae \& Schopen in 1899 for a brachiopod, and by Fucini, 1901 for a cephalopod. Based on the homonymy, Tomlin in 1930 renamed the genus "Geyeria" as Plagigeyeria with Plagigeyeria plagiostoma as type species and the Vrelo Bosna (581 $\mathrm{m}$ a.s.1.) as type locality for the genus. The species inhabits karst conduits under the Igman Massif (1502 m a.s.1.) and northern Bjelašnica Mountains (2067 m a.s.1.), likely drained from Prečko Polje (1002 m a.s.1.).

Plagigeyeria inflata (A. J. Wagner, 1928)

Figs 5C, 6D

Geyeria plagiostoma inflata A. J. Wagner, 1928: 285, pl. 13. figs 68-69, 72.

Plagigeyeria plagiostoma f. inflata - Schütt 1972: 119, fig. 2.

Plagigeyeria plagiostoma - Bank 2013: Fauna Europaea v. 2.6 — Bank \& Neubert 2017: 25.

\section{Diagnosis}

The species can be separated from Plagigeyeria plagiostoma by its larger shell $(2.5 \mathrm{~mm}$ high against $1.9 \mathrm{~mm}$ ) with a more robust and more conical shell shape with more open umbilicus and less blunt apex, by larger, more expanded aperture and by coarser ribs with different cancellate surface of the nepionic whorl.

\section{Distribution}

Only known from the type locality in Vrelo Bosne (581 m a.s.1.) near Ilidža, South of Sarajevo.

\section{Remarks}

Plagigeyeria inflata (A. J. Wagner, 1928) was described from the same spring where the empty shells of P. plagiostoma had been present and, supposing their subspecific status and identical locality, the two species were synonymized by Schütt (1972) and then again in the Fauna Europaea (Bank 2013). Nevertheless, I have to note their conchological distinctness without intermediates, and that both species were found in the same locality only as empty shells washed together within the recent thanatocoenoses of the spring zone. We have no idea about the underground aquifer range and about its mutually separated cave branches. It is very common in the morphology of many spring caves, that the large isolated, hydrologically active cave passages converge their flow just upstream of the spring outlet. Thus we cannot exclude the presence of two separated species or populations existing within one cave system without being sympatric. The recent thanatocoenoses do not represent their true habitat. Both species are very well differentiated by their shell shape and size (Wagner 1928; Schütt 1972) without any intermediate and I prefer to treat them as two independent species. 


\section{Plagigeyeria ljutaensis sp. nov. urn:1sid:zoobank.org:act:A8D69E19-07EA-4432-9C5A-7FE2DA89BBC4}

Figs 5D, 6A

\section{Type material}

\section{Holotype}

BOSNIA AND HERCEGOVINA • 1 shell; Bosnian Federation, Herzegovina-Neretva Canton, Konjic

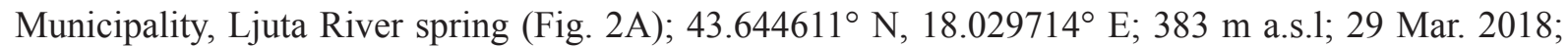
J. Grego, D. Angyal, G. Jakab and M. Olšavský leg.; HNHM-MOLL-104180.

\section{Paratypes}

BOSNIA AND HERCEGOVINA • 37 shells; same data as for holotype; HNHM-MOLL-104181/1, SBMNH 626401/6, coll. Grego/19, coll. Glöer/1.

\section{Dimensions (holotype)}

H 2.09 mm; W 1.49 mm; BH 1.16 mm; BW 0.93 mm; AH 0.9 mm; AW 0.78 mm.

\section{Etymology}

Named after the type locality: Ljuta River spring (as called in material citation).

\section{Description}

The elongate-conical shell is $2.1 \mathrm{~mm}$ in height, with blunt elevated apex, milky-white colour and five inflated whorls separated by a deep suture. Shell surface finely axially ribbed with weak corrugated spiral ribs forming a cancellate structure. Prominent at the nepionic whorl. Wavy spiral cords continue towards the unribbed apex (18 cords) and to protoconch with strongly malleated nucleus. Umbilicus narrow slit-like. Excentric-oval aperture is attached to the body whorl. Peristome blunt and outward reflexed along the aperture outline. Outer lip lateral profile weakly sinuous, columellar lip is weakly concave. Columellar lip profile weakly concave. Expanded aperture conspicuously protruded against body whorl at frontal view.

\section{Differentiating features}

The new species differs from the geographically close P. plagiostoma species from Vrelo Bosna in Ilidža (Fig. 5A) by its more conical shell with more inflated whorls, blunter apex, more narrow umbilicus and larger aperture.

\section{Habitat}

The shells of the new species were found in the sediments of a large karst spring of Ljuta River (383 m a.s.1.) (right tributary of Neretva River) rising from a small cave in a narrow gorge at the southwestern edge of Bjelašnica Massif (2067 m a.s.1.). The karst conduits are likely draining waters from northern Bjelašnica and from Džepi Polje (830 m a.s.1.). They are captured by a waterworks to supply potable water for Konjic.

\section{Distribution}

Only known from the type locality. 
Plagigeyeria konjicensis sp. nov.

urn:1sid:zoobank.org:act:12169801-D468-422F-A065-0263523FB0B5

Figs 5E, 6B

\section{Type material}

\section{Holotype}

BOSNIA AND HERCEGOVINA • 1 shell; Bosnian Federation, Herzegovina-Neretva Canton, Konjic Municipality, spring at left bank of Ljuta River $300 \mathrm{~m}$ west of Ljuta River spring (Fig. 2C); $43.644130^{\circ} \mathrm{N}$, 18.020711 ${ }^{\circ}$ E; 345 m a.s.1.; 29 Mar. 2018; J. Grego, D. Angyal, G. Jakab, M. Olšavský leg.; HNHMMOLL-104174.

\section{Paratypes}

BOSNIA AND HERCEGOVINA - 21 shells; same data as for holotype; HNHM-MOLL-104175/1, SBMNH 626249/2, coll. Grego/17, coll. Glöer/1.

\section{Dimensions (holotype)}

H 2.09 mm; W 1.28 mm; BH 1.10 mm; BW 0.87 mm; AH 0.84 mm; AW 0.72 mm.

\section{Etymology}

Name derived from Konjic, the closest city to the type locality.

\section{Description}

Slender elongated, $2.1 \mathrm{~mm}$-high shell slightly tapering towards the body whorl; milky-white colour with five convex whorls separated by a deep suture. Shell surface finely and densely axially ribbed. Very faint spiral cords are very close set, almost invisible at the teleoconch, and more prominent at nepionic whorl with 21 close-set spiral cords. Apex blunt and flat, protoconch with very faint spiral cords smoothly fading out towards the smooth, very weakly malleated nucleus. Umbilicus open. Almost round-shaped aperture weakly touching the body whorl in upper columellar part. Peristome blunt, margins reflexed along the aperture outline. Outer lip lateral profile strongly forward protruded and weakly sinuous as well as very weak sinuation present at the almost flat columellar lip profile. Expanded round aperture conspicuously protruding against the body whorl at basal view.

\section{Differentiating features}

The shells of P. konjicensis sp. nov. differ from P. plagiostoma (Fig 5A) and from P. ljutaensis sp. nov. by having a significantly more elongated sub-cylindrical shell with a more blunt apex, a slightly sinuated columellar margin, a less prominent body whorl, by different protoconch structure and by a more rounded aperture.

\section{Habitat}

The empty shells were found in a smaller karst spring rising at the left bank of Ljuta River ( $345 \mathrm{~m}$ a.s.l.) among larger stone debris under the road to Ljuta village; the small rivulet from the spring joining the Ljuta River after $60 \mathrm{~m}$, near the ruins of a water mill. It is likely draining the southernmost tip of Bjelašnica massif, south of the village Vrdolje (between Spiljani, Dubočani, Blace and Vrdolje).

\section{Distribution}

Only known from the type locality. 

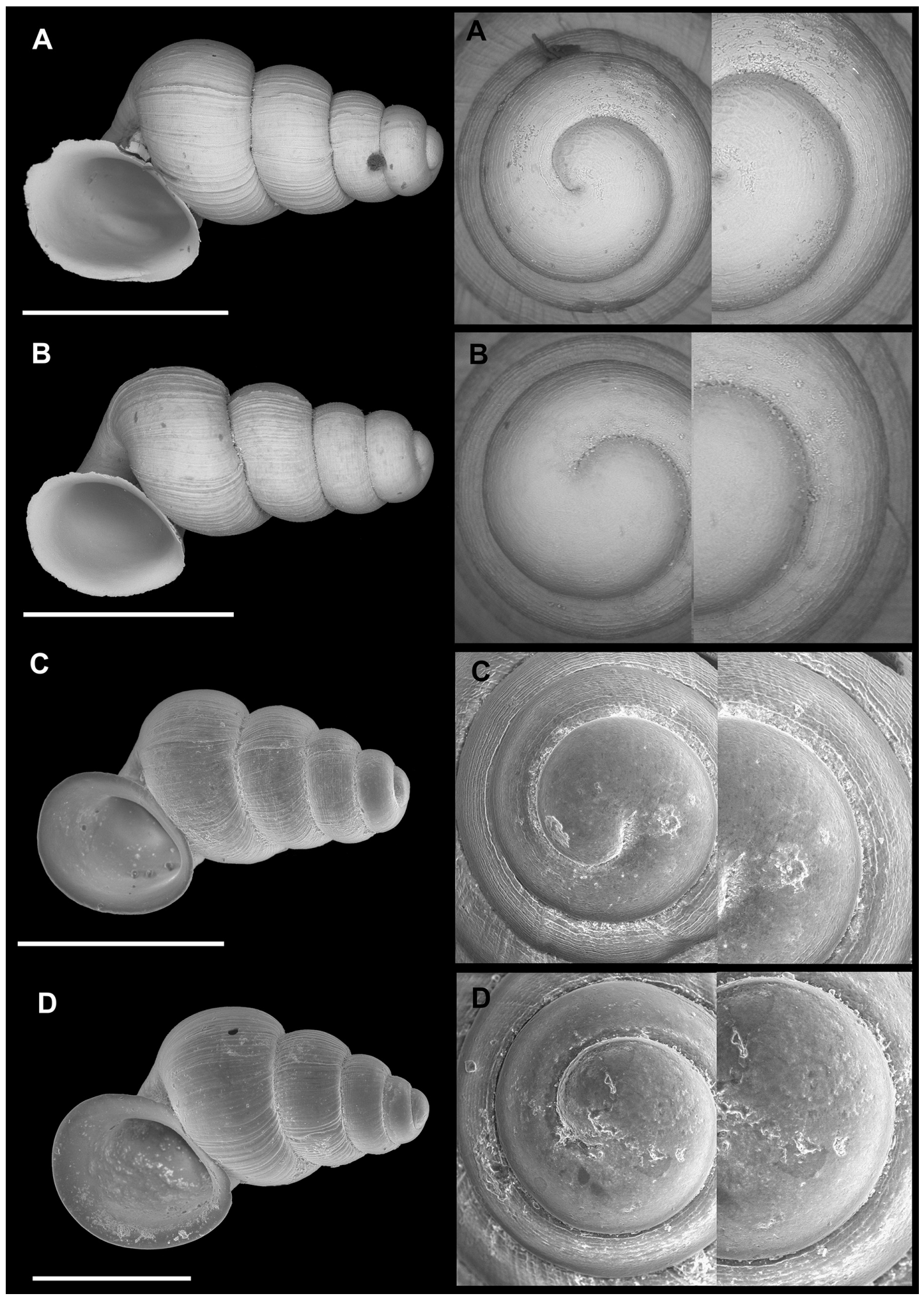

Fig. 6. A. Plagigeyeria ljutaensis sp. nov., Konjic, Vrelo Ljuta, paratype(SBMNH 626401). B. P. konjicensis sp. nov., Konjic, left side spring of Ljuta River, paratype (SBMNH 626249). C. P. plagiostoma (A. J. Wagner, 1914), Sarajevo, Ilidža, Vrelo Bosne, (SBMNH 632718). D. P. inflata (A. J. Wagner, 1928), Sarajevo, Ilidža, Vrelo Bosne (SBMNH 33032). Scale bars = 1 mm (SEM SBMNH Vanessa Delnavaz). 
Plagigeyeria mostarensis Kuščer, 1933.

Figs $7 \mathrm{~A}-\mathrm{E}, 8 \mathrm{D}$

Plagiogeyeria (sic) mostarensis Kuščer, 1933: 62, pl. 1 fig. 3.

Plagigeyeria mostarensis - Jaeckel, Klemm \& Meise 1957: 174. — Jaeckel 1967: 92. — Schütt 1972: 119, pl. 6. fig. 3. - Willmann \& Pieper 1978: 126. - Bole \& Velkovrh 1986: 202, fig. 37. — Bodon, Manganelli \& Giusti 1996: 33, fig. 13. — Bank 2013: Fauna Europaea v. 2.6.

\section{Diagnosis}

Shell elongate-conical with distinct regular ribbing, deep suture and very widely expanded, trumpetlike aperture stepwise pronounced at the basal view. The lateral and columellar profiles of the aperture are characteristically sinuated. Umbilicus slit-like. Nepionic whorl ribbed, only slight spiral ribs, and protoconch surface covered by irregular spiral ribs with inter-rib granulations, nucleus weakly malleated.

\section{Distribution}

Known from the springs of rivers Buna (36 m a.s.1.) and Bunica (55 m a.s.1.) southwest of Mostar. Springs are most likely draining water through karst conduits from Trusinsko Polje (866 m a.s.1.), Nevesinjsko Polje (817 m a.s.l.) and Rotimlja Polje (422 m a.s.l.).

\section{Remarks}

Kuščer (1933) described P. mostarensis with the type locality as the vrelo "Buna" (36 m a.s.l.). However, the Buna spring hosts a different morphotype, while the typical morphotype can be found in the nearby Vrelo "Bunica" (55 m a.s.1.). He also reported the same type locality for P. ovalis, which was not confirmed in Vrelo "Buna" but only in the Vrelo "Bunica" (see remark on P. ovalis). Both species were also figured by Schütt as from the Vrelo "Bunica". We suppose that Kuščer's specimens were actually collected from Vrelo "Bunica", which most likely represents the true type locality of both taxa. It is probable that both springs were treated as the one well-known Vrelo "Buna" on the original collection label. The shells of $P$. mostarensis known from the Vrelo "Buna" (Buna morphotype) (Fig. 5D-E) differ from the typical form figured by Kušcer and known only from the Vrelo "Bunica" (Bunica morphotype) (Fig. 5A-C) by their more pagoda shape of shell with more angled whorls with different suture and different shape of marginal sinuation. The Buna morphotype of $P$. mostarensis is predominantly found in the deposits of the large main stream of Buna River. In all four small side streams at the left bank rising 300-600 m downstream from the main Buna resurgence the empty shells of P. pseudocostellina sp. nov. (Fig. 5G-H) can be found. These are separated by a straight, not sinuated, rounded aperture very similar to Paladilhiopsis (Costellina)

Fig. 7 (next page). A. Plagigeyeria mostarensis, Kuščer 1933, holotype, from Kuščer 1933, assigned to Izvor Buna in Blagaj but rather represents the form from near spring Bunica in Hodbina. B. P. mostarensis, hypotype of Schütt, 1970, from spring Bunica (SMF 221236). C. P. mostarensis, likely topotype from spring Bunica (JG F1146). D-E. P. mostarensis var., from spring of Buna assigned as type locality (JG F0536). Fa-Fb. Paladilhiopsis (Costellina) turrita (Kuščer, 1933) paratype and holotype from Kuščer 1933, spring Izvor in valley of river Jadro near Split. G. P. pseudocostellina sp. nov., left bank side spring of river Buna $400 \mathrm{~m}$ from main spring (holotype HNHM-MOLL-104164). H. P. pseudocostellina sp. nov., left bank side spring of river Buna $200 \mathrm{~m}$ from main spring (paratype JG F1140). I. Travunijana ovalis (Kuščer, 1933), holotype from Kuščer, assigned to Izvor Buna in Blagaj but not found in assigned locality, only in spring Bunica in Hodbina. J-K. T. ovalis (Kuščer, 1933), spring Bunica near Hodbina (JG F1145). L. T. robusta (Schütt, 1959), Trebinje district, Tučevac spring at right bank of Trebišnjica River (JG F1163). M. T. robusta, Trebinje district, Gorica, cave Vruljak 1 (JG F0831). N. T. robusta asculpta (Schütt, 1972), spring Ombla (Dubrovačka Rijeka) at Komolac near Dubrovnik (JG F1080). 


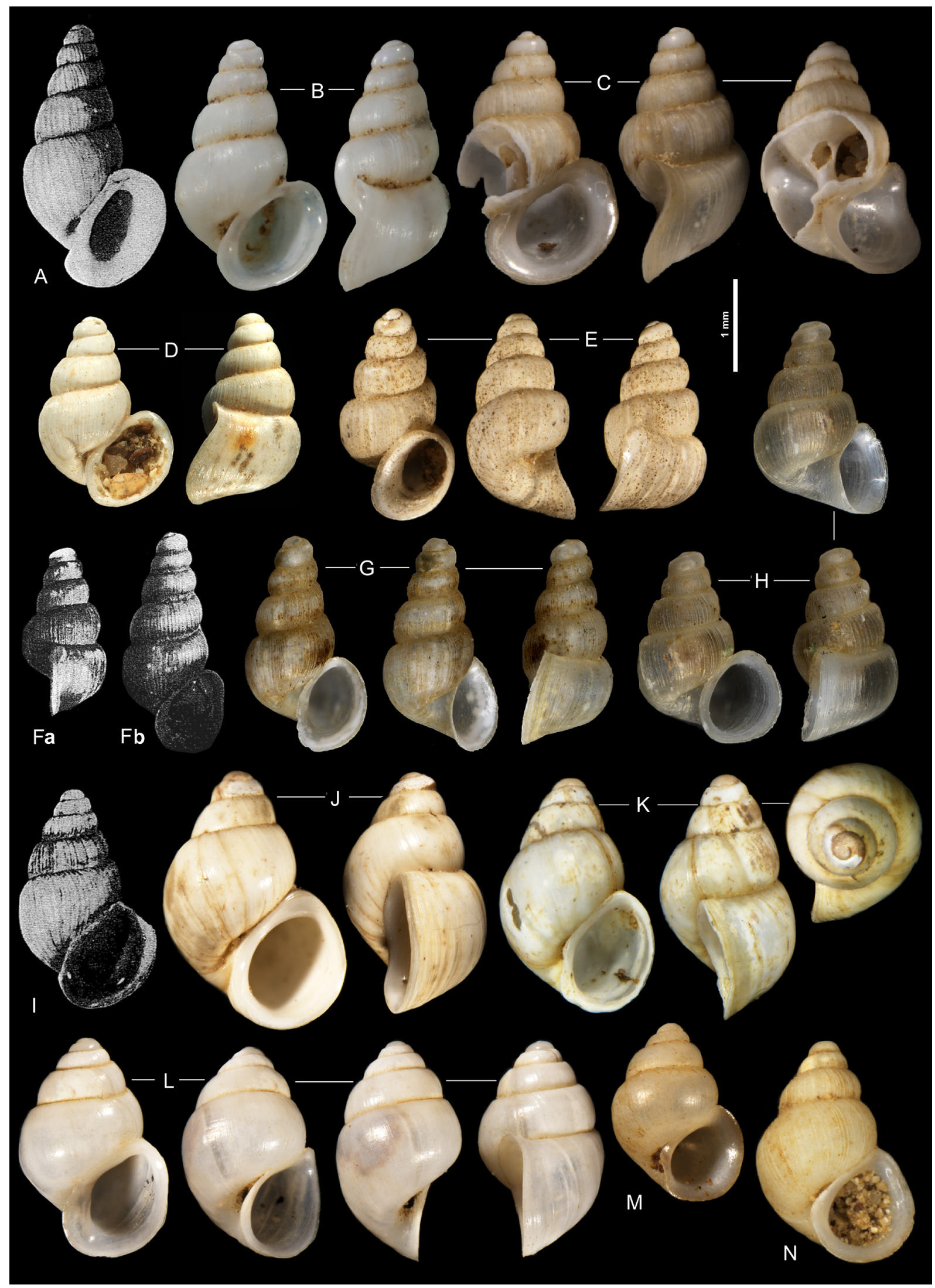


turrita (Kuščer, 1933) (known only from the small spring Izvor in Jadro Valley near Split, Croatia). The taxonomical importance of the Buna morphotype is still under investigation and for the time being, it is listed under P. mostarensis. Plagigeyeria reischuetzorum described herein from Vrelo "Vrijeka" in Dabarsko Polje (472 m a.s.1.) in the upper Bregava Basin, which is likely draining the karstwater from Slato Polje (1012 m a.s.l.) and Lukavačko Polje ( $895 \mathrm{~m}$ a.s.l.), is morphologically the closest relative of $P$. mostarensis. The karst conduits of Bregava Basin indicate at least an occasional divergence of its waters into the Vrelo "Bunica" (55 $\mathrm{m}$ a.s.1.), thus their close relation is not surprising.

Plagigeyeria pseudocostellina sp. nov. urn:1sid:zoobank.org:act:09A7B3DE-5B03-46E1-A0F9-A07BFEDBCA4B

Figs $7 \mathrm{G}-\mathrm{H}, 8 \mathrm{~B}$

\section{Type material}

\section{Holotype}

BOSNIA AND HERCEGOVINA • 1 shell; Bosnian Federation, Mostar Municipality, Blagaj, left bank springs of Buna River $400 \mathrm{~m}$ from main Buna River Spring, Vrelo "Buna"; $43.256090^{\circ} \mathrm{N}, 17.900073^{\circ} \mathrm{E}$; 36 m a.s.l.; 30 Mar. 2018; J. Grego, D. Angyal, G. Jakab and M. Olšavský leg.; HNHM-MOLL-104164.

\section{Paratypes}

BOSNIAAND HERCEGOVINA • 15 shells; same data as for holotype; SBMNH 626414/10, coll. Grego/9 - 26 shells; Bosnian Federation, Mostar Municipality, Blagaj, spring at left bank of Buna River, under road, $500 \mathrm{~m}$ from main Buna River Spring; $43.256090^{\circ} \mathrm{N}, 17.900073^{\circ} \mathrm{E} ; 36 \mathrm{~m}$ a.s.1.; 30 Mar. 2018; J. Grego, D. Angyal, G. Jakab and M. Olšavský leg.; HNHM MOLL 104177/1, coll. Grego/24, coll. Glöer/1 - 5 shells; Bosnian Federation, Mostar Municipality, Blagaj, spring at left bank of Buna River, under road close to bridge towards mosque, $600 \mathrm{~m}$ from main Buna River Spring; $43.256518^{\circ} \mathrm{N}, 17.897381^{\circ} \mathrm{E}$; 36 m a.s.l.; 30 Mar. 2018; J. Grego, D. Angyal, G. Jakab and M. Olšavský leg.; coll. Grego/5.

\section{Dimensions}

Holotype: H 2.34 mm; W 1.30 mm; BH 1.28 mm; BW 1.00 mm; AH 0.97 mm; AW 0.95 mm.

Paratype: H 2.10 mm; W 1.55 mm; BH 1.34 mm; BW 1.03 mm; AH 1.00 mm; AW 0.86 mm.

\section{Etymology}

Named after its resemblance to Costellina turrita (Kuščer, 1933), known from a small spring named Izvor in the valley of the Jadro near Split, Croatia.

\section{Description}

Elongate-pyramidal shell $2.3 \mathrm{~mm}$ high, with rounded blunt apex; milky-yellowish corneous translucent colour with five convex whorls separated by a deep suture. The shell surface is densely covered by lamellar ribs, the ribbing is absent at the nepionic whorl, where it is replaced by 24 densely set spiral ribs cross-sected by fine axial growth lines forming a cancellate structure. Spiral ribs fading down adapically, in pre-nepionic whorl forming faint transversal intercostal structures. Wavy spiral ribs continue towards the nucleus with intercostal granulation. Umbilicus open. Aperture elongate oval to rounded, expanded, shortly attached to the body whorl. Peristome blunt, and outward reflexed along the aperture outline. Outer lip lateral profile straight and flat as well as flat along the columellar lip. Aperture slightly, sometimes conspicuously protruded against the teleoconch and body whorl profile at basal view. 

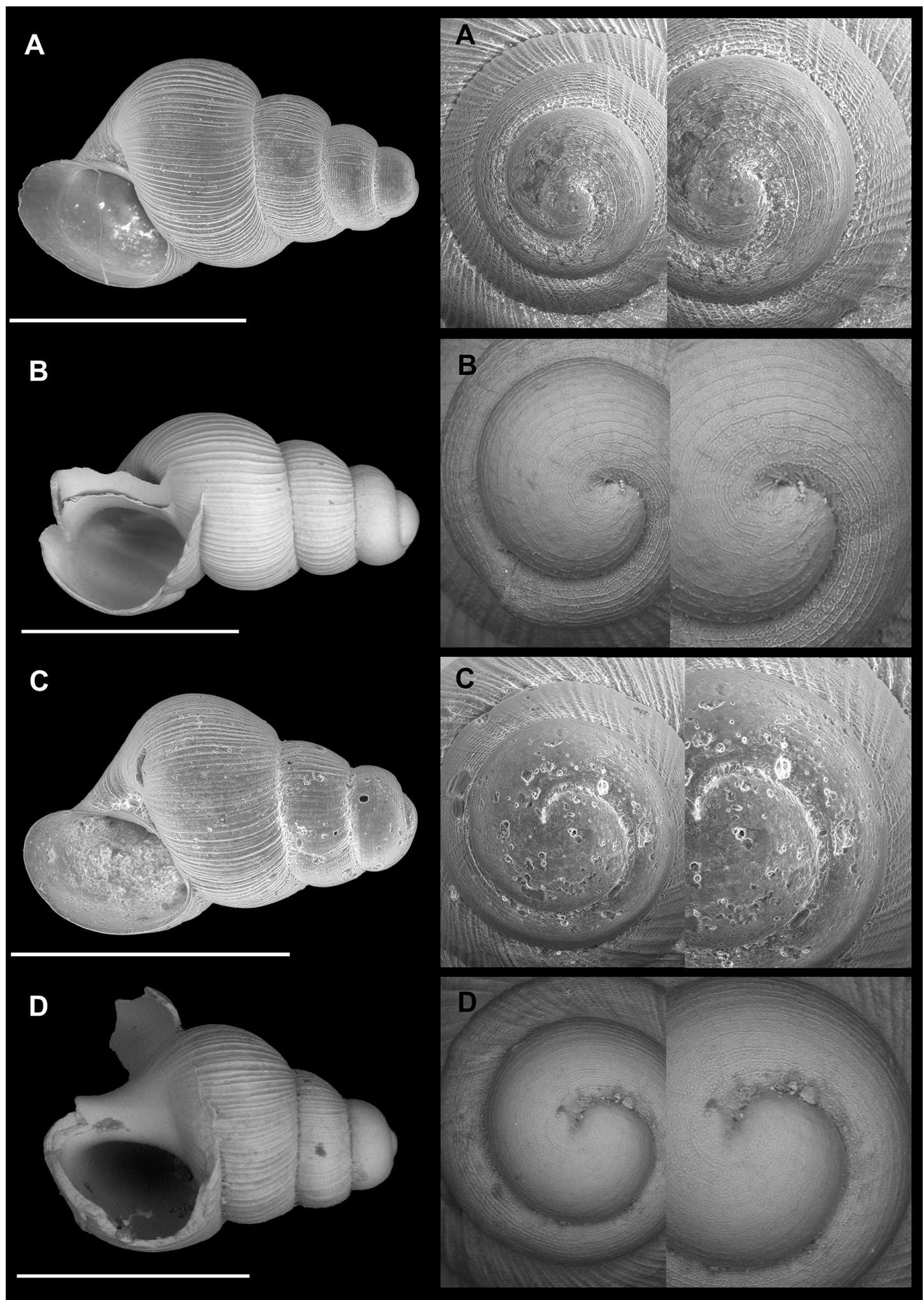

Fig. 8. A. Plagigeyeria reischuetzorum sp. nov., Bjeljani, Dabarsko Polje, Vrelo Vruljak, paratype (SBMNH 632724). B. P. pseudocostellina sp. nov., Blagaj, side spring of Buna at left bank, paratype (SBMNH 626414). C. P. mostarensis Kuščer, 1933, Blagaj Izvor Bune (SBMNH 626411). D. P. mostarensis Kuščer, 1933, Hodbina, Izvor Bunice (SBMNH 626405). Scale bars $=1 \mathrm{~mm}$ (SEM SBMNH Vanessa Delnavaz). 


\section{Differentiating features}

The new species differs from P. mostarensis (Fig. 5A-C) mainly by its straight labral and columellar margins and more open umbilicus. While possessing a similar shell morphology to Costellina turrita (Kuščer, 1933) (Fig. 5F) from the family Moitessieriidae, it differs by having a more open umbilicus and a more oval and more open aperture. Shell morphometry comparison with the related species is presented in the Table 1.

\section{Habitat}

The type specimens were found in sandy sediments washed out from the four small side springs at the right bank of Bunica River about 300-600 m from the main spring of Buna River (36 m a.s.l.). The position of sandy sediments and condition of the fragile shells suggest better adaptation of the new species to an interstitial habitat than we experienced in any other species of Plagigeyeria, which, in contrast, are more specialised to open phreatic cave habitats. The small springs likely draining the low karst plateau situated at the southern foot of the mountain range west of Blagaj without interconnection to the main karst conduit of the Buna.

\section{Distribution}

The new species is so-far known only from the four small springs of the type locality at the left bank of river Buna in Blagaj, while a local Buna form of P. mostarensis (Fig. 5D-E) can be found in the sediment of the main spring of Buna River. The typical morphotype of $P$. mostarensis is found in the nearby spring of river Bunica near Hodbina (Fig. 5A-C) and we suppose this is the type locality, which was erroneously confused with the Buna spring by Kuščer (1933).

\section{Remarks}

The shell morphology similarity to the moitessieriid Paladilhiopsis (Costellina) turrita could suggest an interlink towards Plagigeyeria mostarensis and other members of the genus Plagigeyeria, and its possible affiliation to the family Moitessieriidae.

Plagigeyeria reischuetzorum sp. nov. urn:1sid:zoobank.org:act:A15894D4-DED0-4678-938A-FE39F32E0C51

Figs $8 \mathrm{~A}, 9 \mathrm{G}-\mathrm{J}$

\section{Type material}

\section{Holotype}

BOSNIA AND HERCEGOVINA • 1 shell; Republika Srpska, Bileća Municipality, Berkovići, Vrelo "Vrijeka" in Dabarsko Polje NW of Bjeljani (Fig. 2B-G); $43.07472222^{\circ}$ N, 18.23916667 E; 483 m a.s.1.; Aug. 2009; Alexander Reischütz, Nicole Steiner-Reischütz and Peter L. Reischütz leg.; NHMW 111678.

\section{Paratypes}

BOSNIA AND HERCEGOVINA - 49 shells; same data as for holotype; NHMW 111679/1, HNHMMOLL-104165/1, coll. Reischütz/45, coll. Grego/2 • 21 shells; same locality as holotype; Mar. 2010; Alexander Reischütz, Nicole Steiner-Reischütz and Peter L. Reischütz leg.; coll. Reischütz/19, coll. Grego/2 - 3 shells; same locality as holotype; 31 Mar. 2018; J. Grego, D. Angyal, G. Jakaba and M. Olšavský leg.; SBMNH 626404/1, coll. Grego/2 - 18 shells; same locality as holotype; 22 Apr. 2019; J. Grego, G. Jakab, M. Olšavský and M. Kováčiková leg.; coll. Grego/16.

\section{Other material}

BOSNIA AND HERCEGOVINA • 3 shells; Republika Srpska, Bileća Municipality, Orahovice, Estavela "Obod" in Fatničko Polje; 22 Apr. 2019; J. Grego, G. Jakab, M. Olšavský and M. Kováčiková leg.; $43.018543^{\circ} \mathrm{N}, 18.348643^{\circ} \mathrm{E} ; 452 \mathrm{~m}$ a.s.l.; coll. Grego/3. 
Table 1. Shell morphometry comparison of Plagigeyeria lewarnei sp. nov., P. mostarensis Kuščer, 1933, $P$. pseudocostellina sp. nov. and $P$. reischuetzorum sp. nov.

\begin{tabular}{|c|c|c|c|c|c|c|c|c|c|c|c|c|c|c|c|}
\hline Species & Specimen & $\mathrm{mm}$ & $\mathrm{mm}$ & $\begin{array}{c}\text { BH } \\
\mathrm{mm}\end{array}$ & $\mathrm{mm}$ & $\mathrm{mm}$ & $\begin{array}{l}\text { AW } \\
\mathrm{mm}\end{array}$ & CA & $\mathbf{H} / \mathbf{W}$ & $\begin{array}{l}\mathbf{A H} \\
/ \\
\mathbf{A W}\end{array}$ & $\begin{array}{l}\text { W / } \\
\text { BW }\end{array}$ & $\begin{array}{l}\text { H/ } \\
\text { BH }\end{array}$ & $\begin{array}{l}\mathbf{H} / \\
\mathbf{A H}\end{array}$ & $\begin{array}{l}\mathbf{W} / \\
\mathbf{A W}\end{array}$ & $\begin{array}{l}\mathbf{H} / \\
(\mathbf{W}- \\
\mathbf{B W})\end{array}$ \\
\hline $\begin{array}{l}\text { Plagigeyeria } \\
\text { mostarensis }\end{array}$ & $\begin{array}{l}\text { Holotype } \\
\text { from Kuščer } \\
1933\end{array}$ & 2.79 & 1.52 & 1.66 & 1.10 & 1.51 & 1.24 & 43 & 1.84 & 1.22 & 1.38 & 1.68 & 1.85 & 1.23 & 6.64 \\
\hline $\begin{array}{l}\text { Plagigeyeria } \\
\text { mostarensis }\end{array}$ & $\begin{array}{l}\text { Hypotype } \\
221236 \\
\text { SMF }\end{array}$ & 2.69 & 1.62 & 1.62 & 1.21 & 1.14 & 1.20 & 45 & 1.66 & 0.95 & 1.34 & 1.66 & 2.36 & 1.35 & 6.56 \\
\hline $\begin{array}{l}\text { Plagigeyeria } \\
\text { mostarensis }\end{array}$ & $\begin{array}{l}\text { Topotype? } \\
\text { F1146 JG }\end{array}$ & 2.69 & 1.72 & 1.79 & 1.38 & 1.34 & 1.45 & 49 & 1.56 & 0.92 & 1.25 & 1.50 & 2.01 & 1.19 & 7.91 \\
\hline $\begin{array}{l}\text { Plagigeyeria } \\
\text { mostarensis var. }\end{array}$ & $\begin{array}{l}\text { Buna } \\
\text { spring JG } \\
\text { F0536 }\end{array}$ & 2.05 & 1.43 & 1.28 & 1.00 & 1.02 & 0.97 & 40 & 1.43 & 1.05 & 1.43 & 1.60 & 2.01 & 1,47 & 4.77 \\
\hline $\begin{array}{l}\text { Plagigeyeria } \\
\text { pseudocostellina } \\
\text { sp. nov. }\end{array}$ & $\begin{array}{l}\text { HNHM } \\
\text { Holotype } \\
104164\end{array}$ & 2.34 & 1.30 & 1.28 & 1.00 & 0.97 & 0.95 & 33 & 1.80 & 1.02 & 1.30 & 1.83 & 2.41 & 1.37 & 7.80 \\
\hline $\begin{array}{l}\text { Plagigeyeria } \\
\text { pseudocostellina } \\
\text { sp. nov. }\end{array}$ & $\begin{array}{l}\text { Paratype } \\
\text { JG F1140 }\end{array}$ & 2.10 & 1.55 & 1.34 & 1.03 & 1.00 & 0.86 & 32 & 1.35 & 1.16 & 1.50 & 1.57 & 2.10 & 1.80 & 4.04 \\
\hline $\begin{array}{l}\text { Plagigeyeria } \\
\text { reischuetzorum } \\
\text { sp. nov. }\end{array}$ & $\begin{array}{l}\text { Holotype } \\
\text { NHMW } \\
111678\end{array}$ & 2.73 & 1.73 & 1.66 & 1.19 & 1.29 & 1.05 & 48 & 1.58 & 1.23 & 1.45 & 1.64 & 2.12 & 1.65 & 5.06 \\
\hline $\begin{array}{l}\text { Plagigeyeria } \\
\text { reischuetzorum } \\
\text { sp. nov. }\end{array}$ & $\begin{array}{l}\text { Paratype } \\
\text { HNHM } \\
104165\end{array}$ & 2.51 & 1.73 & 1.66 & 1.19 & 1.36 & 1.19 & 47 & 1.45 & 1.14 & 1.45 & 1.51 & 1.85 & 1.45 & 4.65 \\
\hline $\begin{array}{l}\text { Plagigeyeria } \\
\text { reischuetzorum } \\
\text { sp. nov. }\end{array}$ & $\begin{array}{l}\text { Paratype } \\
\text { JG F1174 }\end{array}$ & 2.64 & 1.68 & 1.64 & 1.22 & 1.27 & 1.15 & 49 & 1.57 & 1.10 & 1.38 & 1.61 & 2.08 & 1.46 & 5.74 \\
\hline $\begin{array}{l}\text { Plagigeyeria } \\
\text { reischuetzorum } \\
\text { sp. nov. }\end{array}$ & $\begin{array}{l}\text { Paratype } \\
\text { JG F1173 }\end{array}$ & 2.42 & 1.69 & 1.53 & 1.19 & 1.16 & 1.16 & 47 & 1.43 & 1.00 & 1.42 & 1.58 & 2.09 & 1.46 & 4.84 \\
\hline $\begin{array}{l}\text { Plagigeyeria } \\
\text { lewarnei sp. nov. }\end{array}$ & $\begin{array}{l}\text { Holotype } \\
\text { JG F0829 }\end{array}$ & 1.95 & 1.33 & 1.21 & 1.05 & 0.93 & 1.02 & 54 & 1.47 & 0.91 & 1.27 & 1.61 & 2.09 & 1.30 & 6.96 \\
\hline
\end{tabular}

\section{Dimensions}

Holotype: H 2.73 mm; W 1.73 mm; BH 1.66 mm; BW 1.19 mm; AH 1.29 mm; AW 1.05 mm.

Paratypes:

H $2.51 \mathrm{~mm}$; W $1.73 \mathrm{~mm}$; BH $1.66 \mathrm{~mm}$; BW $1.19 \mathrm{~mm}$; AH $1.36 \mathrm{~mm}$; AW $1.19 \mathrm{~mm}$.

H $2.64 \mathrm{~mm}$; W $1.68 \mathrm{~mm}$; BH $1.64 \mathrm{~mm}$; BW $1.22 \mathrm{~mm}$; AH $1.27 \mathrm{~mm}$; AW $1.15 \mathrm{~mm}$.

H 2.42 mm; W 1.69 mm; BH 1.53 mm; BW 1.19 mm; AH 1.16 mm; AW 1.16 mm.

\section{Etymology}

Named after the Austrian malacologists Alexander and Peter L. Reischütz with Nicole Steiner-Reischütz, who were the first to collect the species in the type locality. 


\section{Description}

Shell is narrow-conical, $2.7 \mathrm{~mm}$ high with rounded apex and yellowish corneous periostracum, with five convex pagoduline whorls with rather weak suture. Shell surface finely axially ribbed at late whorls of the teleoconch. Faintly cancellate nepionic whorls covered by 25 close-set spiral ribs. Density of spiral ribs apically decreasing at protoconch to 15 and fading out at malleate nucleus. Space among the protoconch ribs is covered by characteristically granulated surface. Umbilicus narrow slit-like and obscured by the strongly reflexed columellar marginal fold. Larger expanding reflexed trumpet-like aperture irregularly oval and attached to body whorl by a parietal callus. Peristome sharp, and strongly outward reflexed along the aperture outline. Outer lip lateral profile and columellar lip profile characteristically sinuous. Expanded aperture conspicuously protruded against shell outline at basal view.

\section{Differentiating features}

The shells of $P$. reischuetzorum sp. nov. differ from the specimens of $P$. mostarensis known from the spring of the Bunica River near Hodbina (Fig. 5A-C) by their more inflated whorls and less sinuated labral and columellar margins, as well by a more prominent and a less declined aperture at the shell lateral outline. Shell morphometry comparison with the related species is presented in the Table 1.

\section{Habitat}

The type specimens were found in sediments washed out from the cave spring "Sušica Pećina" and its side permanent spring Vrelo "Vrijeka" (483 m a.s.l.) situated $100 \mathrm{~m}$ eastward from the cave and rising from debris under the road to Fatnica. It is a part of northern Bregava Basin, likely draining the karst waters from Lukavačko Polje (895 m a.s.1.) into Dabarsko Polje (472 m a.s.1.). During the sampling in March 2018 the adjacent parts of Dabarsko Polje were flooded by large spring outlets creating a vast lake.

\section{Distribution}

The new species is so-far known only from the type locality.

Plagigeyeria lewarnei sp. nov. urn:lsid:zoobank.org:pub:CC8487E0-169D-4B32-A2AB-F9B34DFB3F3B

Figs 9D, 11B

\section{Type material}

\section{Holotype}

BOSNIAAND HERCEGOVINA • 1 shell; Republika Srpska, Trebinje Municipality, Gorica, Vrelo "Vruljak 1", sandy sediment taken by SCUBA dive ca $200 \mathrm{~m}$ from the cave entrance (Fig. 2F); $42.713736^{\circ} \mathrm{N}$; 18.368096 E; 280 m a.s.l. ; 6 Sep. 2009; Gergely Balázs. leg.; HNHM MOLL 104176.

Fig. 9 (next page). A. Plagigeyeria erossi sp. nov., Mostar district, Komadinovo Vrelo at right bank of Neretva below Donja Jablanica, holotype (HNHM-MOLL- 104166). B-C. P. erossi sp. nov., type locality, paratypes (JG F0518, JG F1122). D. P. lewarnei sp. nov., Trebinje district, Gorica, cave Vruljak, holotype (HNHM-MOLL-104176). E. P. listicaensis sp. nov., Široki Brijeg, Bilo Vrelo (Lištica 2), holotype (HNHM-MOLL-104168). F. P. listicaensis sp. nov., type locality, paratype (JG F1250). G-H. P. reischuetzorum sp. nov., Dabarsko Polje, Vrelo Vrijeka. G. Paratype (HNHM-MOLL-104165). H. Paratype (JG F1173). I. P. reischuetzorum sp. nov., type locality, holotype (NHMW 111678). J. P. reischuetzorum sp. nov., type locality, paratype (JG F1158). K-L. Travunijana gloeri sp. nov., Dabarsko Polje, Vrelo Vrijeka. K. Holotype (HNHM-MOLL-104418). L. Paratype (JG F1340). 


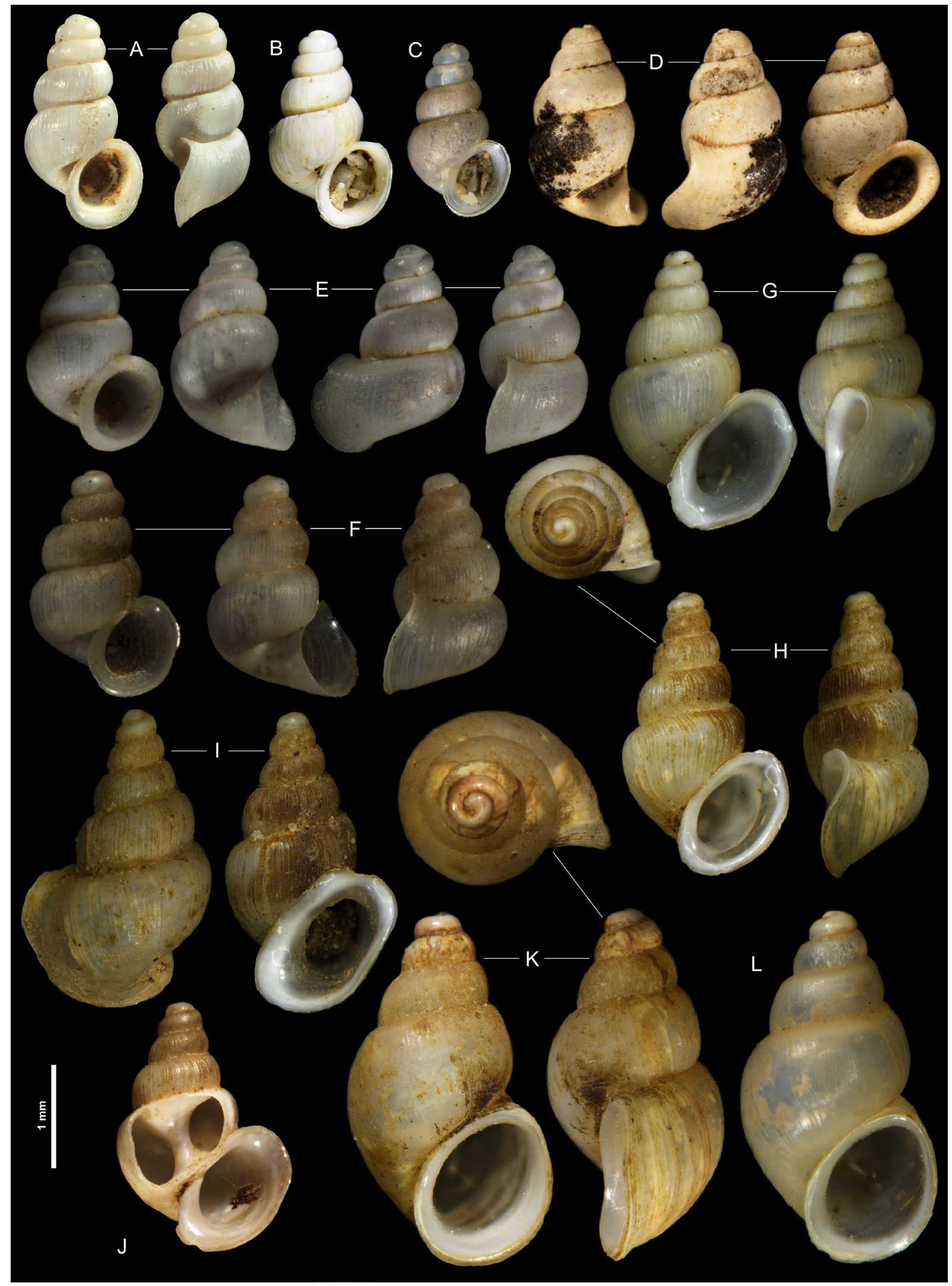


Paratypes

BOSNIA AND HERCEGOVINA • 1 fragmented specimen as for holotype; same data; HNHM MOLL 105099/; Bosnia and Hercegovina • 7 shells; Republika Srpska, Trebinje Municipality, Vrelo "Tučevac" at right bank of Trebišnjica River, $42.714257^{\circ} \mathrm{N} ; 18.303311^{\circ} \mathrm{E} ; 280 \mathrm{~m}$ a.s.1.; 31 Mar. 2018; J. Grego, M. Olšavský, G. Jakab and M. Kováčiková leg.; SBMNH 626406/1 fragmented specimen, JG F1336/6 fragmented specimens.

\section{Dimensions}

Holotype: H 1.95 mm; W 1.32 mm; BH 1.21mm; BW 1.05 mm; AH 0.93 mm; AW 1.05 mm.

\section{Etymology}

Named after Brian Lewarne from The Devon Karst Research Society, Plymouth UK, who leads the "Proteus Project" hypogean species conservation project in Trebinje and supported this study by extensive consultancy about karst groundwater circulation on the studied area.

\section{Description}

Elongate conical shell $1.95 \mathrm{~mm}$ high with four convex whorls (apex of holotype missing) separated with rather weak suture. Shell surface covered by slightly sinuated lamellate axial ribs cross-sected by slightly crenated fine spiral cords. Twelve spiral cords are more prominent at the nepionic whorl forming a cancellate surface. Faint spiral ribs continue through the apex where the axial ribs are missing and slowly fade out at the protoconch covered by malleate structure. Umbilicus narrow slit-like and obscured by the strongly reflexed columellar marginal fold. Expanding trumpet-like reflexed aperture with typically sinuated labral margin adapically forward protruding. The ventral shape of the aperture is oval, protruded against the shell outline and slightly labrally depressed, attached to the body whorl at its columellar side. Peristome blunt and strongly outward reflexed along aperture outline.

\section{Differentiating features}

The shell morphology and surface sculpture of the new species are closely related to those of P. mostarensis, however the new species differs significantly by its much smaller shell with different shape, by more blunt-rounded apex and by the differently shaped aperture, more protruding at its lower margin. Furthermore the radial malleated cord structure of the first protoconch whorl is weaker in the new species. The new species represents an intermediate between $P$. mostarensis and $P$. olsavskyi by its protruding lateral labral profile, however, it differs from the latter by a more closed umbilicus and different shell surface sculpture and by a more smooth protoconch surface.

\section{Habitat}

Only scarce, eroded or fragmented shells have been recovered from the spring and cave sediments of the spring at the right bank of Trebišnjica in Trebinje. This suggests a deep cave habitat remote from the spring head or from the hitherto known cave passages. The cave in the type locality drains the karst aquifers north of Trebinje likely from Ljubomirsko Polje (506 m a.s.1.).

\section{Distribution}

The new species is so-far known only from the type locality and from the Vrelo "Tučevac" in Trebinje. Fragments resembling this species were found in sediments of "Sušicka Jama" Estavelle at the border with Montenegro.

Plagigeyeria zetatridyma (Schütt, 1960)

Plagigeyeria zetaprotogona zetatridyma Schütt, 1960: 149, fig. 4. 
Plagigeyeria zetaprotogona zetatridyma - Schütt 1972: 121, pl. 7. figs 14-16.

Plagigeyeria zetatridyma - Bole \& Velkovrh 1986: 202, fig. 37. — Bodon, Manganelli \& Giusti 1996: 33, fig. 13.

\section{Diagnosis}

Large species $(\max 3.1 \mathrm{~mm})$ with turreted spire and inflated body whorl, very faint and close-set axial striae at shell surface and corrugated varix, faint spiral ribs at early whorls and very expanded trumpetlike aperture with distinctly broadly folded adapical notch groove as well as smoothly impressed posterior channel. Columellar labral fold covering the umbilicus.

\section{Distribution}

Plagigeyeria zetatridyma has its main distribution range over Upper Nikšićko Polje (647 m a.s.l.), Krupac Polje (615 m a.s.1.), Slano Polje (613 m a.s.1.), Slivlje Polje (601 m a.s.1.) and in the main spring of Zeta River in Glava Zete ( $88 \mathrm{~m}$ a.s.1.) as well as in the left side springs of the Zeta River Valley (Viska Vrela, $47 \mathrm{~m}$ a.s.1.) in Montenegro. The empty shells of the species were detected by H. Schütt at Nikšićko Vrelo (342 m a.s.1.) at Miruše, in the basin of the Trebišnjica River, indicating the karstwater and its species divergence between basins of river Drin (Zeta) and Trebišnjica.

\section{Remarks}

Specimens of P. zetatridyma detected by Schütt (1963 and 1972) in one of the main springs of Trebišnjica (Nikšićko Vrelo, $342 \mathrm{~m}$ a.s.l.), show extraordinarily high shell morphology resemblance to the morphotype of the same taxon known from springs (spring Močila) and estavelles (Gornjepoljski Vir, $643 \mathrm{~m}$ a.s.1.) at the north-western edge of Upper Nikšićko Polje (Montenegro). Its presence in a spring supplying the Trebišnjica River Basin represents additional proof of the transboundary groundwater communication with the Zeta River Basin at Nikšičko Polje. It is also possible, that the empty shells are washed from their Zeta Basin habitats into the neighbouring Trebišnjica aquifer only by the interim high water levels. Unfortunately the localities have been flooded by a hydropower dam so, we have lost the chance to get genetical proof of such groundwater divergence.

Plagigeyeria erossi sp. nov. urn:1sid:zoobank.org:act:405BAA2B-296D-4B18-9D62-343C35A6963E

Figs $9 \mathrm{~A}-\mathrm{C}, 10 \mathrm{~A}$

\section{Type material}

\section{Holotype}

BOSNIA AND HERCEGOVINA • 1 shell; Bosnian Federation, Herzegovina-Neretva Canton, Donja Jablanica, Komadinovo Vrelo, $2 \mathrm{~km} \mathrm{SW}$ of, and under the road from Mostar to Jablanica, side outlet of main spring at left bank of Neretva (Fig. 2D); $43.617298^{\circ} \mathrm{N}, 17.741081^{\circ} \mathrm{E} ; 180 \mathrm{~m}$ a.s.1.; 30 Jul. 2016; J. Grego and Z. P. Eröss leg.; HNHM-MOLL-104166.

\section{Paratypes}

BOSNIA AND HERCEGOVINA • 3 shells; same data as for holotype; HNHM-MOLL-104167/1, coll. Grego/1, coll. Erőss/1. • 1 shell; same locality as holotype; 29 Mar. 2018; Jozef Grego leg; coll. Grego/1.

\section{Dimensions}

Holotype: H 2.10 mm; W 1.13 mm; BH 1.25 mm; BW 0.90 mm; AH 0.87 mm; AW 0.72 mm.

Paratypes: 
H $2.01 \mathrm{~mm}$; W $1.28 \mathrm{~mm}$; BH $1.12 \mathrm{~mm}$; BW $0.93 \mathrm{~mm}$; AH $0.88 \mathrm{~mm}$; AW $0.77 \mathrm{~mm}$.

H 1.79 mm; W 1.09 mm; BH $1.12 \mathrm{~mm}$; BW $0.88 \mathrm{~mm}$; AH $0.79 \mathrm{~mm}$; AW $0.70 \mathrm{~mm}$.

\section{Etymology}

Named after my friend Zoltán Péter Erőss, president of the Hungarian Malacological Society, Budapest, who participated in the field trip and brought my attention to the locality of the new species.

\section{Description}

Solid, narrow, conical shell, $2.1 \mathrm{~mm}$ in height, with blunt apex, milky-white colour and four convex whorls separated by a deep suture. Shell surface very finely axially ribbed especially at the late teleoconch and ribs cross-sected by irregular wavy faint spiral structures. Nepionic whorl covered by 18 close-set spiral ribs, continuing apically into fine irregular granulose cord-like structure at protoconch and smoothly malleate nucleus. Umbilicus open, partly obscured by the strongly reflexed columellar margin. Larger expanding reflexed aperture oval, attached to the body whorl in its upper columellar part. Peristome blunt, reflexed along aperture outline. Outer lip lateral profile characteristically sinuous adapically as well as having a characteristic sinuation which is present at the columellar lip. Expanded aperture stepwise protruded against body whorl at frontal view.

\section{Differentiating features}

Compared with the geographically closest Plagigeyeria mostarensis Kuščer, 1933 (Hercegovina, Blagaj) (Fig. 7A-E), the new species differs by its smaller cylindrical and less conical shell shape, blunter rounded apex and less prominent protoconch, more open umbilicus, as well as by a proportionally smaller and more oval aperture. The new species has a characteristic sinuation at outer and inner lips and a less prominent aperture within the shell peripheral outline. The shell morphology of the new species is closely related to Plagigeyeria plagiostoma (A. J. Wagner, 1914) from the spring of the river Bosna near Ilidža, which differs by its more slender shell, cylindrical shape, more open umbilicus, different sculpture of the protoconch, proportionally smaller aperture and a weaker marginal sinuation. Shell morphometry comparison with the related species is presented in the Table 2.

\section{Habitat}

The type locality is a large karst spring rising at the right bank of Neretva River among large stone blocks under highway (Sarajevo-Mostar) and draining the limestone massif of Mt Prenj (2115 $\mathrm{m}$ a.s.l.) in Čvrsnica Massif (highest peak Pločno, $2228 \mathrm{~m}$ a.s.1.). Due to a strong current in the spring zone, there was not enough fine sediment in the main spring zone, but empty shells had been found in two smaller side springs at the left side of the main outlet. This species most likely inhabits an undiscovered karst conduit upstream the spring inside the Čvrsnica Massif.

\section{Distribution}

Only known from the type locality.

$$
\begin{gathered}
\text { Plagigeyeria olsavskyi sp. nov. } \\
\text { urn:1sid:zoobank.org:act:24E627A4-A78B-4447-BB44-B34BB9D0F943 }
\end{gathered}
$$

Figs 5F-I, 10C-D

\section{Type material}

\section{Holotype}

BOSNIA AND HERCEGOVINA • 1 shell; Herzegovina-Neretva Canton, Studenci, Vrelo "Kajtazovina" in Studeničko Polje (Fig. 3D); 43.169696 N, 17.628004 E; 53 m a.s.1.; 1 Apr. 2018; J. Grego, D. Angyal, G. Jakab, M. Olšavský leg; HNHM-MOLL-104178. 

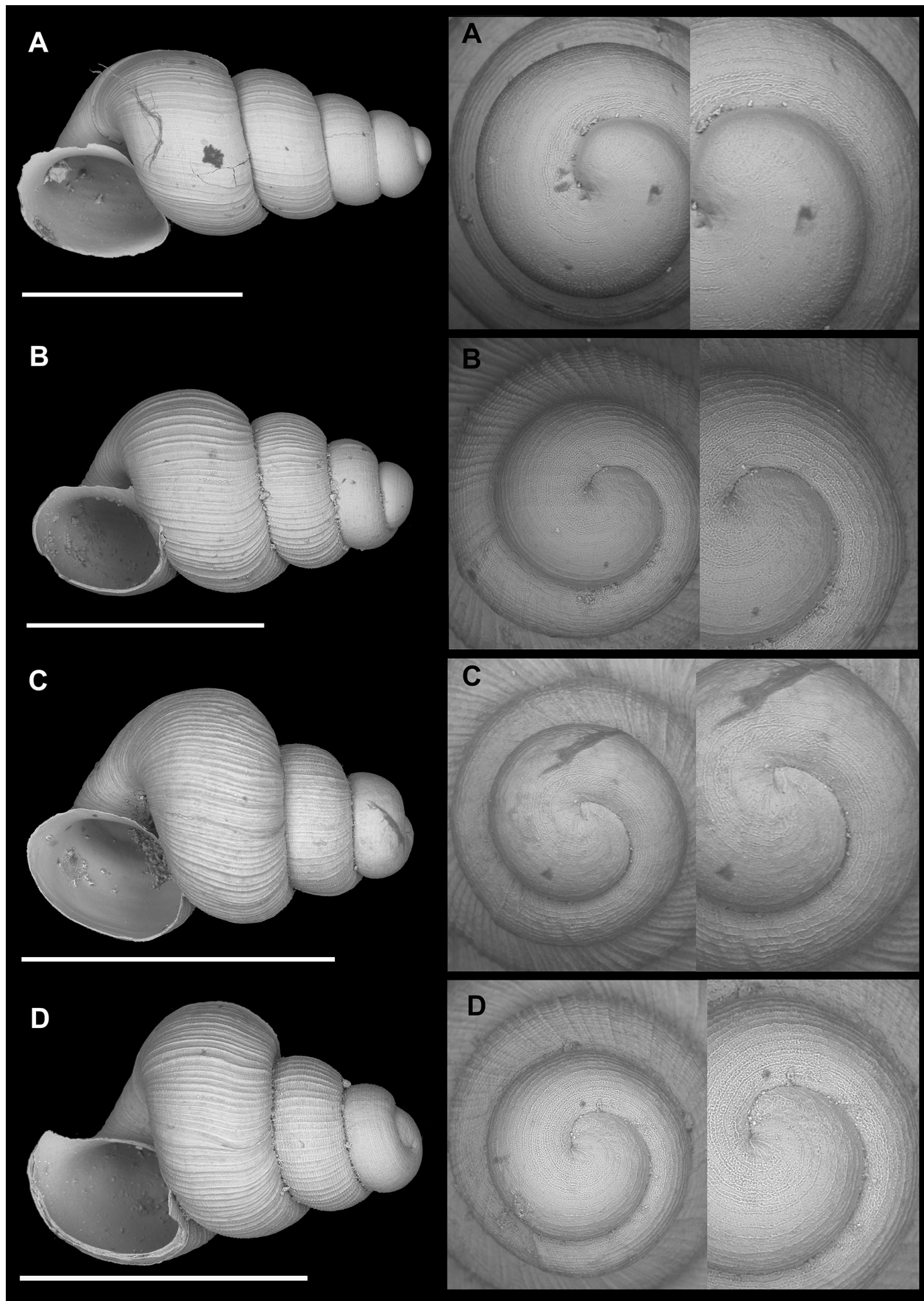

Fig. 10. A. Plagigeyeria erossi sp. nov., Donja Jablanica, Komadinovo Vrelo, paratype (SBMNH 632010). B. P. listicaensis sp. nov., Široki Brijeg, Vrelo Lištice, Bilo Vrilo, paratype (SBMNH 626350). C. P. olsavskyi sp. nov., Studenci, Vrilo Kajtazovina, paratype (SBMNH 626245). D. P. olsavskyi sp. nov., Ljubuški, spring Mali Prokop, paratype (SBMNH 626260). Scale bars $=1 \mathrm{~mm}$ (SEM SBMNH Vanessa Delnavaz). 
Paratypes

BOSNIA AND HERCEGOVINA $\bullet 3$ shells; same data; coll. Grego/3 $\bullet 45$; same locality as holotype; 22 Apr. 2019; J. Grego, M. Olšavský, G. Jakab and M. Kováčiková leg.; HNHM-MOLL-105100/1, coll. Grego/44 • 41 shells; West Herzegovina Canton, Ljubuški district, Donji Proboj, Vrelo "Mali Prokop" $400 \mathrm{~m}$ north of road M6; $43.223905^{\circ} \mathrm{N}, 17.514440^{\circ} \mathrm{E} ; 98 \mathrm{~m}$ a.s.l. (Fig. 4C); 2 Apr. 2018; J. Grego, D. Angyal, G. Jakab and M. Olšavský leg.; SBMNH 626260/7, coll. Grego/32, coll. Reischütz/1.

\section{Dimensions}

Holotype: H 2.01 mm; W 1.52 mm; BH 1.22 mm; BW 1.07 mm; AH 0.9 mm; AW 0.93 mm.

Paratypes:

H $2.00 \mathrm{~mm}$; W $1.32 \mathrm{~mm}$; BH $1.25 \mathrm{~mm}$; BW $0.99 \mathrm{~mm}$; AH $0.94 \mathrm{~mm}$; AW $0.79 \mathrm{~mm}$.

H $2.03 \mathrm{~mm}$; W $1.42 \mathrm{~mm}$; BH $1.25 \mathrm{~mm}$; BW $1.01 \mathrm{~mm}$; AH $0.85 \mathrm{~mm}$; AW $1.07 \mathrm{~mm}$.

H 1.87 mm; W 1.34 mm; BH 1.19 mm; BW 0.96 mm; AH 0.86 mm; AW 0.69 mm.

\section{Etymology}

Named after my friend Mário Olšavský, speleologist and geologist from Banská Bystrica, Slovakia, who actively helped with the sampling of springs in our field trips.

\section{Description}

Elongate-pyramidal $2 \mathrm{~mm}$-high shell with flat blunt apex and four convex whorls separated by a deep suture; milky-white colour and distinctly open umbilicus. Shell surface covered by fine regular axial ribs at last two teleoconch whorls, nepionic whorl with cancellate surface and dominating axial ribs, embryonal whorls covered by irregular faint spiral rib-like structure with raised malleate structures at the interspaces. Rounded or slightly oval aperture with slightly outward reflexed margins. Sharp peristome slightly expanded along aperture outline. Outer lip lateral profile forward protruding and very weakly sinuous adapically and straight to very weakly sinuated at the columellar lip. The aperture is conspicuously stepwise protruded against the shell outline at the basal view.

\section{Differentiating features}

The shell morphology of the new species closely resembles P. inflata (A. J. Wagner, 1928), differing by its smaller and less conical shell, less open umbilicus, more blunt apex and a more rounded shape of the aperture. From P. plagiostoma it differs by having a more robust shell shape with a more prominent body whorl and broader umbilicus. Shell morphometry comparison with the related species is presented in the Table 2.

\section{Habitat}

The type lot was found in the sediments of two springs at a left tributary of the Tihaljina (Trebižat) River:

1. Vrelo "Kajtazovina" (53 m a.s.1.) in Studeničko Polje (LT): a large karst spring with a small cave and ruins of a water mill with a bridge at its mouth. Spring likely draining the water from Čitlučko Polje (217 m a.s.l.).

2. Vrelo "Mali Prokop" (98 m a.s.l): A small spring rising from a crack in the limestone massif just beside the road to the northernmost houses of Donji Proboj Village. The small amount of sandy sediment is accumulated at the bottom of the shallow spring basin. The spring outlet looks to be almost constant during the year and not influenced by the spring maxima in the other neighbouring springs. It is likely draining the water from Rašanjsko Polje (344 m a.s.1.). 


\title{
Distribution
}

Only known from the type locality and the nearby Vrelo "Mali Prokop" in Donji Proboj in the left tributary of the Tihaljina (Trebižat) River.

\author{
Plagigeyeria listicaensis, sp. nov. \\ urn:1sid:zoobank.org:act:BBEACB84-641D-4E59-B97A-C748FF43816F
}

Figs 7E-F, 8B

\section{Type material}

\section{Holotype}

BOSNIA AND HERCEGOVINA • 1 shell; Bosnian Federation, West Herzegovina Canton, Široki Brijeg, Vrelo Lištica 2 (BiloVrilo) $1 \mathrm{~km}$ north of the city (Fig. 4B); 43.396392 ${ }^{\circ} \mathrm{N}, 17.596437^{\circ} \mathrm{E} ; 319 \mathrm{~m}$ a.s.1.; 2 Apr. 2018; J. Grego, D. Angyal, G. Jakab and M. Olšavský leg.; HNHM-MOLL-104168.

\section{Paratypes}

BOSNIA AND HERCEGOVINA - 37 shells; same data as for holotype; HNHM-MOLL-104169/1, SBMNH 626250/4, coll. Grego/31, coll. Glöer/1.

\section{Dimensions}

Holotype: H 2.00 mm; W 1.30 mm; BH 1.23 mm; BW 1.03 mm; AH 0.91 mm; AW 0.81 mm.

Paratype: H 2.21 mm; W 1.47 mm; BH 1.28 mm; BW 1.09 mm; AH 0.98 mm; AW 0.88 mm.

\section{Etymology}

Named after the type locality in the springs of Lištica River in the vicinity of Široki Brijeg.

\section{Description}

Solid elongate-conical shell, $2.0 \mathrm{~mm}$ high, apex blunt, slightly elevated protoconch, with four convex whorls and deep suture. Shell colour is translucent-whitish. Teleoconch surface covered by fine axial ribs and fine, close-set spiral cords forming a distinct cancellate structure. With dominating axial ribs. Nepionic whorl covered by 25 wavy granulose close-set spiral ribs connected by granulose irregular structures fusing at malleate apex. Open umbilicus, partly obscured by reflexed columellar margin. The elongate-oval reflexed aperture attached to body whorl by a narrow sulcus. Peristome reflexed along the aperture outline. Outer lip weakly sinuous, straight at its columellar side and slightly protruded adapically. Columellar lip with straight lateral profile. Aperture at basal view stepwise protruded against body whorl.

\section{Differentiating features}

Compared to P. olsavskyi sp. nov., differs by its broader, more conical shell, less blunt protoconch, a proportionally larger aperture, more closed umbilicus and more coarsely sculptured protoconch. Shell morphometry comparison with the related species is presented in the Table 2.

\section{Habitat}

The type locality consists of two large karst spring risings at Lištica valley $1 \mathrm{~km}$ north of Široki Brijeg at $319 \mathrm{~m}$ a.s.l. The southern spring is captured for a water supply, while the northern one has a deep spring lake with free outflows through old water mill ruins, where the sandy sediment samples were taken. The spring is most likely getting its water through karst conduits from Rakitno Polje ( $890 \mathrm{~m}$ a.s.l.) and from the sinkholes around the upper Ugrovača River. 
Table 2. Shell morphometry comparison of Plagigeyeria plagiostoma (A. J. Wagner, 1914), P. ljutaensis sp. nov., . konjicensis sp. nov., P. olsavskyi sp. nov., P. ozimeci sp. nov., P. erossi sp. nov. and P. listicaensis sp. nov.

\begin{tabular}{|c|c|c|c|c|c|c|c|c|c|c|c|c|c|c|c|}
\hline Species & Specimen & $\begin{array}{l}\mathbf{H} \\
\mathrm{mm}\end{array}$ & $\frac{\mathbf{W}}{\mathrm{mm}}$ & $\begin{array}{l}\text { BH } \\
\mathrm{mm}\end{array}$ & $\begin{array}{l}\text { BW } \\
\mathrm{mm}\end{array}$ & $\begin{array}{c}\mathbf{A H} \\
\mathrm{mm}\end{array}$ & $\begin{array}{l}\mathbf{A W} \\
\mathrm{mm}\end{array}$ & $\begin{array}{l}\mathbf{C A} \\
\circ\end{array}$ & $\mathbf{H} / \mathbf{W}$ & $\begin{array}{l}\mathbf{A H} \\
/ \\
\mathbf{A W}\end{array}$ & $\begin{array}{l}\text { W/ } \\
\text { BW }\end{array}$ & $\begin{array}{l}\text { H/ } \\
\mathbf{B H}\end{array}$ & $\begin{array}{l}\mathbf{H} / \\
\mathbf{A H}\end{array}$ & $\begin{array}{l}\text { W/ } \\
\text { AW }\end{array}$ & $\begin{array}{l}\text { H/ } \\
\text { (W- } \\
\text { BW) }\end{array}$ \\
\hline $\begin{array}{l}\text { Plagigeyeria } \\
\text { plagiostoma }\end{array}$ & $\begin{array}{l}\text { Topotype } \\
\text { JG F1116 }\end{array}$ & 1.91 & 1.25 & 1.10 & 0.93 & 0.81 & 0.63 & 25 & 1.53 & 1.29 & 1.34 & 1.74 & 2.36 & 1.98 & 5.97 \\
\hline $\begin{array}{l}\text { Plagigeyeria } \\
\text { inflata }\end{array}$ & $\begin{array}{l}\text { Topotype } \\
\text { JG F1117 }\end{array}$ & 2.44 & 1.85 & 1.58 & 1.31 & 1.16 & 1.01 & 33 & 1.32 & 1.15 & 1.41 & 1.54 & 2.10 & 1.83 & 4.52 \\
\hline $\begin{array}{l}\text { Plagigeyeria } \\
\text { ljutaensis } \\
\text { sp. nov. }\end{array}$ & $\begin{array}{l}\text { Holotype } \\
\text { HNHM } \\
104180\end{array}$ & 2.09 & 1.49 & 1.16 & 0.93 & 0.90 & 0.78 & 35 & 1.40 & 1.15 & 1.60 & 1.80 & 2.32 & 1.91 & 3.73 \\
\hline $\begin{array}{l}\text { Plagigeyeria } \\
\text { konjicensis } \\
\text { sp. nov. }\end{array}$ & $\begin{array}{l}\text { Holotype } \\
\text { HNHM } \\
104174\end{array}$ & 2.09 & 1.28 & 1.10 & 0.87 & 0.84 & 0.72 & 32 & 1.63 & 1.17 & 1.47 & 1.90 & 2.49 & 1.78 & 5.10 \\
\hline $\begin{array}{l}\text { Plagigeyeria } \\
\text { olsavskyi }\end{array}$ & $\begin{array}{l}\text { Holotype } \\
\text { HNHM } \\
104178\end{array}$ & 2.01 & 1.52 & 1.22 & 1.07 & 0.90 & 0.93 & 34 & 1.32 & 0.97 & 1.42 & 1.65 & 2.23 & 1.63 & 4.47 \\
\hline $\begin{array}{l}\text { Plagigeyeria } \\
\text { olsavskyi } \\
\text { sp. nov. }\end{array}$ & $\begin{array}{l}\text { Paratype } \\
\text { JG F1192 }\end{array}$ & 2.00 & 1.32 & 1.25 & 0.99 & 0.94 & 0.79 & 37 & 1.52 & 1.19 & 1.33 & 1.60 & 2.13 & 1.67 & 6.06 \\
\hline $\begin{array}{l}\text { Plagigeyeria } \\
\text { var. olsavskyi } \\
\text { sp. nov. }\end{array}$ & $\begin{array}{l}\text { Prokop } \\
\text { HNHM } \\
104176\end{array}$ & 2.03 & 1.42 & 1.25 & 1.01 & 0.85 & 1.07 & 34 & 1.43 & 0.79 & 1.41 & 1.62 & 2.39 & 1.33 & 4.95 \\
\hline $\begin{array}{l}\text { Plagigeyeria } \\
\text { olsavskyi } \\
\text { sp. nov. }\end{array}$ & $\begin{array}{l}\text { Paratype } \\
\text { (Mali } \\
\text { Prokop) } \\
\text { JG F1209 }\end{array}$ & 1.87 & 1.34 & 1.19 & 0.96 & 0.86 & 0.69 & 34 & 1.40 & 1.25 & 1.40 & 1.57 & 2.17 & 1.94 & 4.92 \\
\hline $\begin{array}{l}\text { Plagigeyeria } \\
\text { listicaensis } \\
\text { sp. nov. }\end{array}$ & $\begin{array}{l}\text { Holotype } \\
\text { HNHM } \\
104168\end{array}$ & 2.00 & 1.30 & 1.23 & 1.03 & 0.91 & 0.81 & 35 & 1.54 & 1.12 & 1.26 & 1.63 & 2.20 & 1.60 & 7.41 \\
\hline $\begin{array}{l}\text { Plagigeyeria } \\
\text { listicaensis } \\
\text { sp. nov. }\end{array}$ & $\begin{array}{l}\text { Paratype } \\
\text { JG F1250 }\end{array}$ & 2.21 & 1.47 & 1.28 & 1.09 & 0.98 & 0.88 & 37 & 1.50 & 1.11 & 1.35 & 1.73 & 2.26 & 1.67 & 5.82 \\
\hline $\begin{array}{l}\text { Plagigeyeria } \\
\text { ozimeci } \\
\text { sp. nov. }\end{array}$ & $\begin{array}{l}\text { Holotype } \\
\text { HNHM } \\
104173\end{array}$ & 1.97 & 1.45 & 1.28 & 1.03 & 1.03 & 0.83 & 43 & 1.36 & 1.24 & 1.41 & 1.54 & 1.91 & 1.75 & 4.69 \\
\hline $\begin{array}{l}\text { Plagigeyeria } \\
\text { ozimeci } \\
\text { sp. nov. }\end{array}$ & $\begin{array}{l}\text { Paratype } \\
\text { JG F1215 }\end{array}$ & 1.82 & 1.38 & 1.17 & 1.00 & 0.98 & 0.79 & 40 & 1.32 & 1.24 & 1.38 & 1.56 & 1.86 & 1.75 & 4.79 \\
\hline $\begin{array}{l}\text { Plagigeyeria } \\
\text { ozimeci } \\
\text { sp. nov. }\end{array}$ & $\begin{array}{l}\text { Paratype } \\
\text { HNHM } \\
104179\end{array}$ & 1.90 & 1.28 & 1.24 & 0.93 & 1.00 & 0.86 & 40 & 1.48 & 1.16 & 1.38 & 1.53 & 1.90 & 1.49 & 5.43 \\
\hline $\begin{array}{l}\text { Plagigeyeria } \\
\text { erossi sp. nov. }\end{array}$ & $\begin{array}{l}\text { Holotype } \\
\text { HNHM } \\
104166\end{array}$ & 2.10 & 1.13 & 1.25 & 0.90 & 0.87 & 0.72 & 32 & 1.86 & 1.21 & 1.26 & 1.68 & 2.41 & 1.57 & 9.13 \\
\hline $\begin{array}{l}\text { Plagigeyeria } \\
\text { erossi sp. nov. }\end{array}$ & $\begin{array}{l}\text { Paratype } \\
\text { JG F0518 }\end{array}$ & 2.01 & 1.28 & 1.12 & 0.93 & 0.88 & 0.77 & 33 & 1.57 & 1.14 & 1.38 & 1.79 & 2.28 & 1.66 & 5.74 \\
\hline $\begin{array}{l}\text { Plagigeyeria } \\
\text { erossi sp. nov. }\end{array}$ & $\begin{array}{l}\text { Paratype } \\
\text { JG F1122 }\end{array}$ & 1.79 & 1.09 & 1.12 & 0.88 & 0.79 & 0.70 & 33 & 1.64 & 1.13 & 1.24 & 1.60 & 2.27 & 1.56 & 8.52 \\
\hline
\end{tabular}




\title{
Distribution
}

The species is known only known from the type locality.

\author{
Plagigeyeria ozimeci $\mathrm{sp}$. nov. \\ urn:1sid:zoobank.org:act:D4D9C7F0-9C1D-44EF-9933-C27CB712A994
}

Figs $11 \mathrm{~A}, 12 \mathrm{~F}-\mathrm{K}$

\section{Type material}

\section{Holotype}

BOSNIA AND HERCEGOVINA - 1 shell; West Herzegovina Canton, Vitina, Vrelo "Vrioštica" (Fig. 3E); 43.237595 ${ }^{\circ} \mathrm{N}, 17.485963^{\circ}$ E; 98 m a.s.l.; 2 Apr. 2018; J. Grego, D. Angyal, G. Jakab and M. Olšavský leg; HNHM-MOLL-104173.

\section{Paratypes}

BOSNIA AND HERCEGOVINA - 8 shells; same data as for holotype; HNHM-MOLL-104179/1, SBMNH 626245/2, coll. Grego/5 - 2 shells; same locality as for holotype; 22 Apr. 2019; J. Grego, M. Olšavský, G. Jakab and M. Kováčiková leg.; coll. Grego/2;

\section{Dimensions}

Holotype: H 1.97 mm; W 1.45 mm; BH 1.28 mm; BW 1.03 mm; AH 1.03 mm; AW 0.83 mm.

Paratypes:

H $1.82 \mathrm{~mm}$; W $1.38 \mathrm{~mm}$; BH $1.17 \mathrm{~mm}$; BW $1.00 \mathrm{~mm}$; AH $0.98 \mathrm{~mm}$; AW $0.79 \mathrm{~mm}$. H 1.90 mm; W 1.28 mm; BH 1.24 mm; BW 0.93 mm; AH 1.00 mm; AW 0.86 mm.

\section{Etymology}

Named after my friend Roman Ozimec from Zagreb, Croatia who has contributed much to the speleobiology and cave exploration of the Dinarides.

\section{Description}

Narrow conical shell $1.97 \mathrm{~mm}$ high, with blunt globose apex and four convex whorls and semi-deep suture. Shell yellowish corneous colour with rusty-brown inorganic incrustations. Teleoconch surface covered by fine regular axial ribbing cross-sected by irregular spiral cord-like structures forming a distinct cancellated surface. The embryonal whorl surface has 16 irregular spiral cords with malleated interstices and a number of cords gradually decreasing towards the malleate apex. The body whorl could bear 2-4 distinct sharp varices. Umbilicus open. Aperture elongate-rhomboid shaped, labrally depressed. Margins outward reflexed. Outer lip lateral profile has sinuous protrusion at depressed part. Columellar lip lateral profile straight with slight elevation at its central part. Expanded aperture stepwise protruding against the teleoconch basal periphery outline.

\section{Differentiating features}

Shells of $P$. ozimeci sp. nov. can be found sympatrically with P. vriosticaensis sp. nov. and can be distinguished by its smaller, more conical shell shape with lower numbers of whorls and more robust shell shape with depressed labral margin. Shells of $P$. ozimeci frequently have on their body whorl one or more varices with sharp, winged frame not seen in other species of Plagigeyeria. From other similar sized members of the genus, it can be differentiated by its proportionally larger and more elongated aperture with labrum elevated and depressed at its middle part. The columellar peristome has a characteristic double sinuation not seen in other species. Shell morphometry comparison with the related species is presented in the Table 2. 


\section{Habitat}

The type locality is a large karst spring (98 $\mathrm{m}$ a.s.l.) rising from a cave under a limestone cliff in the town of Vitina. A stone wall holding a pond directs the springwater to a small disused powerplant at the left side of spring zone. A significant amount of water is also leaking under the stone wall to a lower, shallow ornamental duckpond at the northern edge of the town park. Vrelo "Vrioštica" is likely supplied by water drained in Rakitno Polje (890 m a.s.1) and through Kočerinsko Polje (302 m a.s.1.).

\section{Distribution}

Only known from the type locality.

Plagigeyeria jakabi sp. nov. urn:1sid:zoobank.org:act:8FFFE2C7-2DB1-4F0E-9FAD-D8027A4DD709

Fig. 12A-B

\section{Type material}

\section{Holotype}

BOSNIA AND HERCEGOVINA -1 shell; Herzegovina-Neretva Canton, Studenci-Guljevina, Vrilo "Guljevina" (Fig. 4A); 43.181472 N, 17.602929 E; 77 m a.s.1.; 2 Apr. 2018; J. Grego, D. Angyal, G. Jakab and M. Olšavský leg.; HNHM-MOLL-104172.
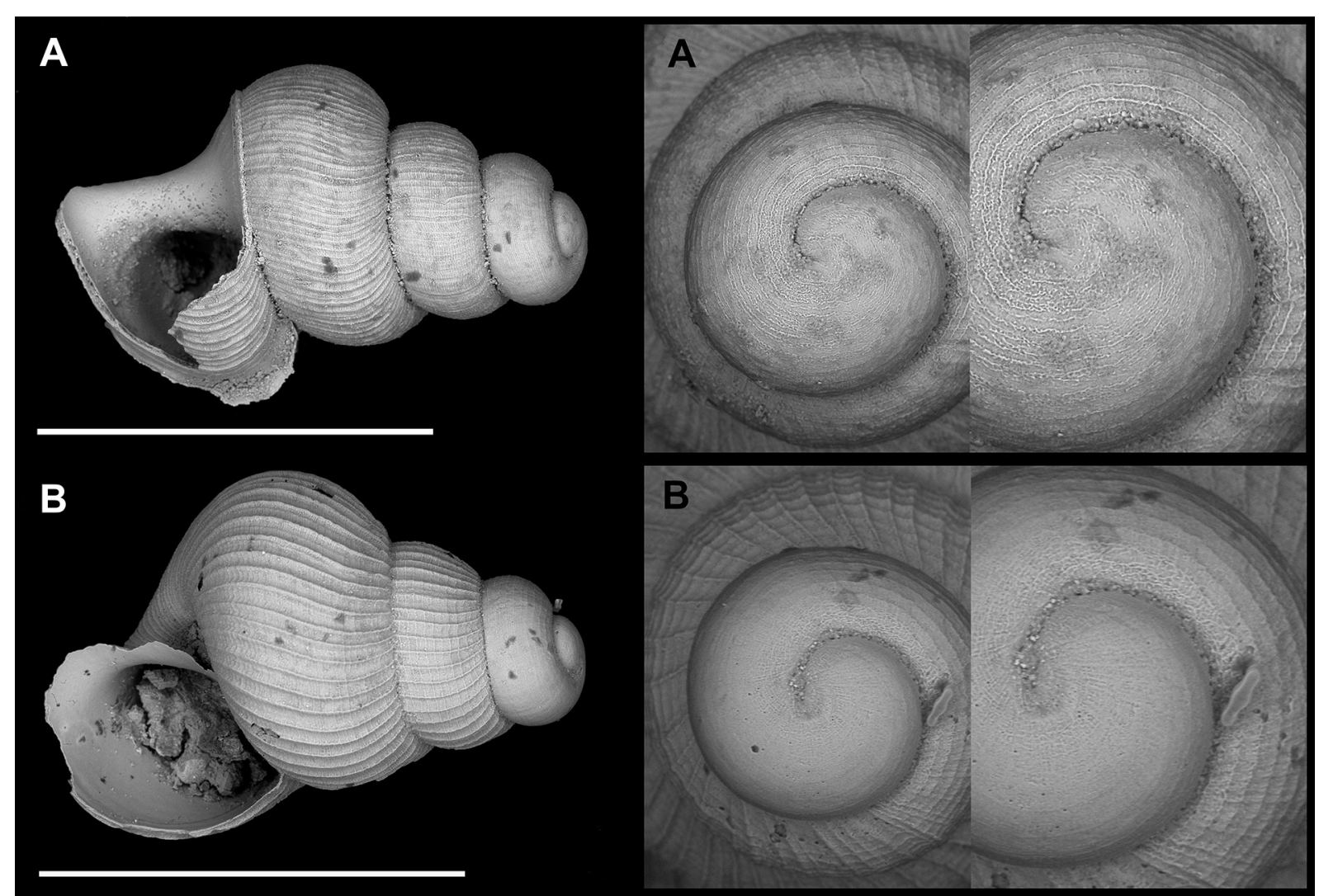

Fig. 11. A. Plagigeyeria ozimeci sp. nov., Vitina, Vrilo Vrioštica, paratype SBMNH 626440. B. Plagigeyeria lewarnei sp. nov., spring Tučevac in Trebinje, SBMNH 626406. Scale bars $=1 \mathrm{~mm}$ (SEM SBMNH Vanessa Delnavaz). 


\section{Paratype}

BOSNIA AND HERCEGOVINA • 1 shell; same data as for holotype; coll. Grego/1.

\section{Dimensions}

Holotype: H 2.52 mm; W 1.58 mm; BH 1.45 mm; BW 1.14 mm; AH 1.17 mm; AW 1.00 mm.

Paratype: H 2.45 mm; W 1.40 mm; BH 1.45 mm; BW 1.14 mm; AH 1.13 mm; AW 1.07 mm.

\section{Etymology}

Named after my friend Gabriel Jakab, a speleologist from Plešivec, Slovakia, who supported all our Balkan field trips and helped to explore the type locality of the new species.

\section{Description}

Solid elongate-conical $2.5 \mathrm{~mm}$-high shell with blunt rounded apex, milky-yellowish colour and 4.5 convex inflated whorls separated by a deeply cut suture. Shell surface regularly axially ribbed with faintly granulose interstices. Nepionic whorl almost smooth with faint spiral rib-like structures. Umbilicus narrow, slit-like, partly obscured by the reflexed columellar marginal fold. The larger expanding reflexed aperture is tear-shaped with a sinulus-like extension at its upper-right end. Peristome blunt and trumpetlike reflexed along aperture outline, especially at upper marginal part. Outer lip lateral profile very weakly sinuous and characteristic sinuation present at columellar lip profile. Expanded aperture stepwise and conspicuously protruded against body whorl at basal view.

\section{Differentiating features}

P. jakabi sp. nov. differs from all related species like P. angyaldorkae sp. nov. by a typically tear-shaped aperture with a sharply conspicuous indication of a posterior channel and an oval rounded bottom part of the aperture and, by a less sinuated labral margin and by a more prominent body whorl. Shell morphometry comparison with the related species is presented in the Table 3 .

\section{Habitat}

The shells of the new species were washed out from subterranean aquifers through a large karst spring "Vrilo" in Guljevina (77 m a.s.1.). The spring rising under the thick vertical Neogene limestone cliff with a smaller cave left from the outlet and water mill ruins downstream. It is likely draining the water from Mokro Polje (230 m a.s.1.).

\section{Distribution}

Only known from the type locality.

Plagigeyeria angyaldorkae sp. nov. urn:1sid:zoobank.org:act:6BC5A082-0F63-4116-92B3-3BD320D5D1FA

Fig. 12E

\section{Type material}

\section{Holotype}

BOSNIA AND HERCEGOVINA • West Herzegovina Canton, Tihaljina District, Lukende, Jakšenica Village, "Vrelo Jakšenica" (Fig. 3F); 43.322897 N, $17.373026^{\circ}$ E; 173 m a.s.1.; 2 Apr. 2018; J. Grego, D. Angyal, G. Jakab and M. Olšavský leg.; HNHM-MOLL-104163. 
Table 3. Shell morphometry comparison of Plagigeyeria jakabi sp. nov., P. angyaldorkae sp. nov. and P. vriosticaensis $\mathrm{sp}$. nov.

\begin{tabular}{|c|c|c|c|c|c|c|c|c|c|c|c|c|c|c|c|}
\hline Species & Specimen & $\begin{array}{l}\mathbf{H} \\
\mathrm{mm}\end{array}$ & $\frac{\mathbf{W}}{\mathrm{mm}}$ & $\begin{array}{l}\text { BH } \\
\mathrm{mm}\end{array}$ & $\frac{\mathbf{B W}}{\mathrm{mm}}$ & $\begin{array}{c}\mathbf{A H} \\
\mathrm{mm}\end{array}$ & $\frac{\mathbf{A W}}{\mathrm{mm}}$ & $\begin{array}{l}\text { CA } \\
\circ\end{array}$ & $\mathbf{H} / \mathbf{W}$ & $\begin{array}{l}\mathbf{A H} \\
/ \\
\mathbf{A W}\end{array}$ & $\begin{array}{l}\text { W / } \\
\text { BW }\end{array}$ & $\begin{array}{l}\mathbf{H} / \\
\mathbf{B H}\end{array}$ & $\begin{array}{l}\mathbf{H} / \\
\mathbf{A H}\end{array}$ & $\begin{array}{l}\text { W / } \\
\text { AW }\end{array}$ & $\begin{array}{l}\text { H/(W- } \\
\text { BW) }\end{array}$ \\
\hline $\begin{array}{l}\text { Plagigeyeria } \\
\text { jakabi sp. nov. }\end{array}$ & $\begin{array}{l}\text { Holotype } \\
\text { HNHM } \\
104172\end{array}$ & 2,52 & 1,58 & 1,45 & 1,14 & 1,17 & 1,00 & 42 & 1,59 & 1,17 & 1,39 & 1,74 & 2,15 & 1,58 & 5,73 \\
\hline $\begin{array}{l}\text { Plagigeyeria } \\
\text { jakabi sp. nov. }\end{array}$ & $\begin{array}{l}\text { Paratype } \\
\text { JG F1204 }\end{array}$ & 2,45 & 1,40 & 1,45 & 1,14 & 1,13 & 1,07 & 41 & 1,75 & 1,06 & 1,23 & 1,69 & 2,17 & 1,31 & 9,42 \\
\hline $\begin{array}{l}\text { Plagigeyeria } \\
\text { angyaldorkae } \\
\text { sp. nov. }\end{array}$ & $\begin{array}{l}\text { Holotype } \\
\text { HNHM } \\
104163\end{array}$ & 3,07 & 1,86 & 1,45 & 1,31 & 1,21 & 1,21 & 48 & 1,65 & 1,00 & 1,42 & 2,12 & 2,54 & 1,54 & 5,58 \\
\hline $\begin{array}{l}\text { Plagigeyeria } \\
\text { vriosticaensis } \\
\text { sp. nov. }\end{array}$ & $\begin{array}{l}\text { Holotype } \\
\text { HNHM } \\
100174\end{array}$ & 2,82 & 1,76 & 1,66 & 1,31 & 1,21 & 1,17 & 41 & 1,60 & 1,03 & 1,34 & 1,70 & 2,33 & 1,50 & 6,27 \\
\hline $\begin{array}{l}\text { Plagigeyeria } \\
\text { vriosticaensis } \\
\text { sp. nov. }\end{array}$ & $\begin{array}{l}\text { Paratype } \\
\text { HNHM } \\
104182\end{array}$ & 3,00 & 1,45 & 1,72 & 1,28 & 1,24 & 1,28 & 49 & 2,07 & 0,97 & 1,13 & 1,74 & 2,42 & 1,13 & 17,65 \\
\hline
\end{tabular}

\section{Dimensions}

Holotype: H 3.07 mm; W 1.86 mm; BH 1.45 mm; BW 1.31 mm; AH 1.21 mm; AW 1.21 mm.

\section{Etymology}

Named after my friend Dorottya Angyal from the Budapest Natural History Museum, who substantially helped with the samplings during our field trip.

\section{Description}

Solid, elongate-conical shell, $3.1 \mathrm{~mm}$-high, with 5.5 regularly tapering narrow inflated whorls, deep suture and blunt rounded apex, milky-white colour and fine regular sinuated axial ribs. Late protoconch faintly irregularly spirally ribbed. Umbilicus open, obscured by the outward reflexed flaring columellar margin. Expanding reflexed aperture with irregular elongate-oval shape and a slightly depressed and inward-bent labral margin. The upper labral margin is elongate-flaring. Labral lateral profile protruded and bent backward at the body whorl, columellar margin profile sinuated. Expanded upper tip of aperture is conspicuously protruded, flaring against the frontal shell profile.

\section{Differentiating features}

P. angyaldorkae sp. nov. differs from all other known species of the region by its elongate-conical shell shape with 6 whorls, by more convex whorls and proportionally smaller body whorls and by a characteristically elongated labrally depressed aperture with a slightly depressed labral margin. From Lanzaia ephantota (Megerle von Mühlfeld, 1824) it differs by larger more elongate shell wit finer, more close-set ribbs and more depressed aperture. Shell morphometry comparison with the related species is presented in the Table 3.

\section{Habitat}

The empty shell of this subterranean species was washed out by a middle-sized karst spring $(173 \mathrm{~m}$ a.s.l.) rising from a $1.5 \mathrm{~m}$-broad limestone crack among houses in the village. The strong stream flows under the main road, depositing the sand at a pond just before the old watermill ruins. The spring is likely getting its water from sinkholes north of village Drinovci (245 m a.s.1.) in Imotsko Polje. 


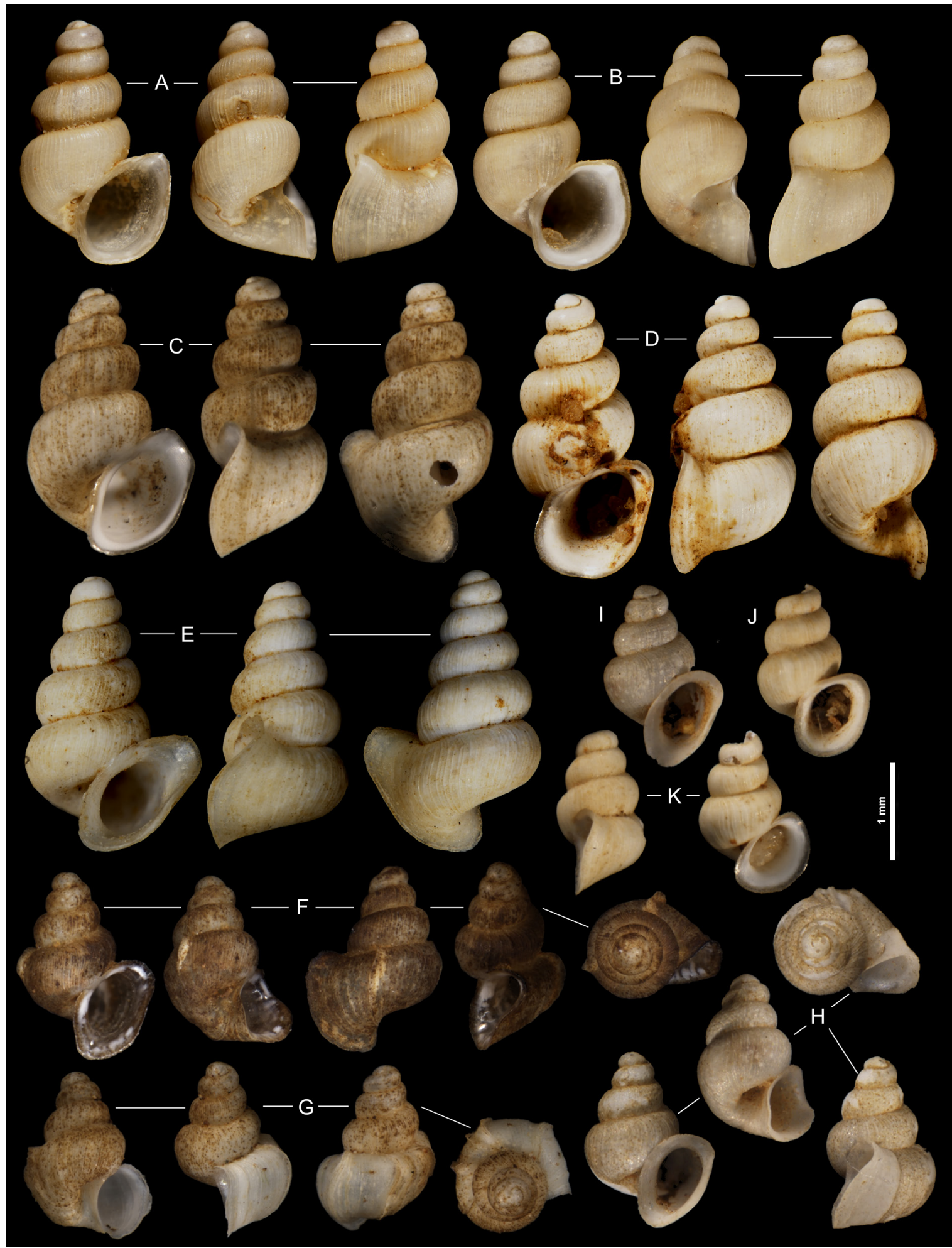

Fig. 12. A-B. Plagigeyeria jakabi sp. nov., Studenci, spring Guljevina A. Holotype (HNHMMOLL-104172). B. Paratype (JG F1204). C-D. P. vriosticaensis sp. nov., Vitina, Vrelo Vrioštica C. Holotype (HNHM-MOLL-104182). D. Paratype (JG F1214). E. P. angyaldorkae sp. nov., Vrelo Jakšenica (holotype HNHM-MOLL- 104163). F. P. ozimeci sp. nov., Vitina, Vrelo Vrioštica, holotype (HNHM-MOLL-104173). G-K. P. ozimeci sp. nov., Vitina, Vrelo Vrioštica, paratypes (JG F1215). 


\section{Distribution}

Only known from the type locality

Plagigeyeria vriosticaensis sp. nov.

urn:Isid:zoobank.org:act:BE0E3ADC-7F3F-4866-9BCD-2769746A2A81

Fig. $12 \mathrm{C}-\mathrm{D}$

\section{Type material}

\section{Holotype}

BOSNIA AND HERCEGOVINA - 1 shell; West Herzegovina Canton, Vitina, Vrelo "Vrioštica" (Fig. 3E); $43.237595^{\circ}$ N, $17.485963^{\circ}$ E; 98 m a.s.1.; 2 Apr. 2018; J. Grego, D. Angyal, G. Jakab and M. Olšavský leg.; HNHM-MOLL-104182.

\section{Paratypes}

BOSNIAAND HERCEGOVINA • 4 shells; same data as for holotype; SBMNH 626400/2, coll. Grego/2.

\section{Dimensions}

Holotype: H 2.82 mm; W 1.76 mm; BH 1.66 mm; BW 1.31 mm; AH 1.21 mm; AW 1.17 mm.

Paratype: H 3.00 mm; W 1.45 mm; BH 1.72 mm; BW 1.28 mm; AH 1.24 mm; AW 1.28 mm.

\section{Etymology}

Named after the type locality: spring of Vrioštica River.

\section{Description}

Elongate oval shell with 4.5 convex whorls and deep suture, $2.8 \mathrm{~mm}$ high, with blunt rounded apex, milky-white colour with rusty incrustations. Shell surface shiny and finely axially ribbed at the teleoconch. Nepionic whorl faintly spirally ribbed. Umbilicus narrow, slit-like. Aperture rhomboid-oval with outward reflex, posteriorly and anteriorly more expanded. Peristome blunt, and reflexed along the aperture outline. Outer lip lateral profile straight and sinuous posteriorly. Sinuation present at columellar marginal profile. Aperture protruded against teleoconch outline from frontal view.

\section{Differentiating features}

The species is closely related to $P$. angyaldorkae sp. nov., from which it differs by having a smaller number of whorls and a more prominent body whorl and, by a more narrow umbilicus and different shape of aperture. Conchologically, it represents an intermediate shell morphology between $P$. angyaldorkae sp. nov. and P. jakabi sp. nov., from which it can be distinguished by its more robust shell shape and different shape of the aperture with much broader posterior channel and by a smaller umbilicus. From sympatric $P$. ozimeci sp. nov. it differs by a larger shell with more whorls, a less conical shell shape and by a different shape of the aperture. Shell morphometry comparison with the related species is presented in the Table 3.

\section{Habitat}

See the habitat of $P$. ozimeci sp. nov.

\section{Distribution}

The species is only known from the type locality. 


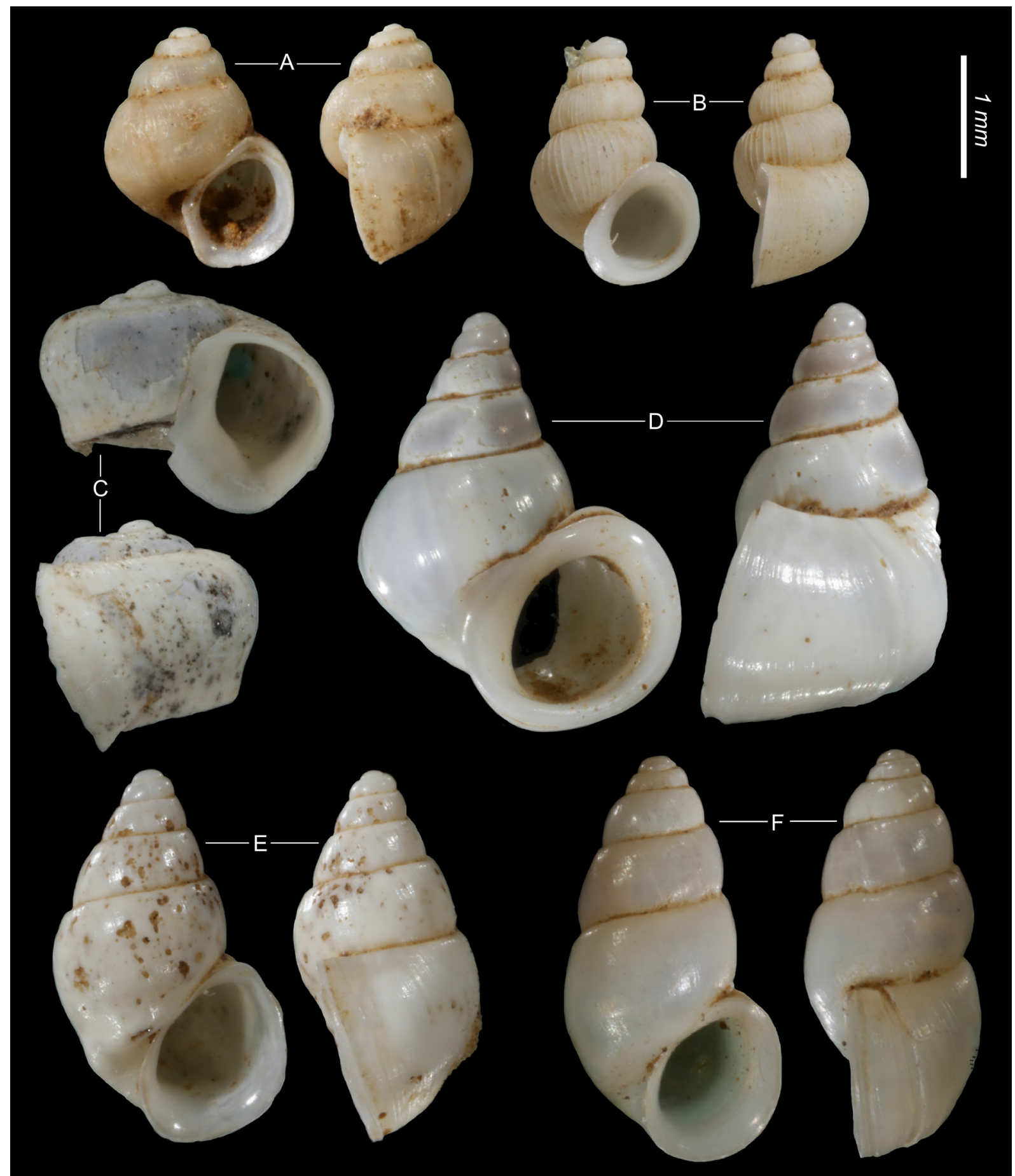

Fig. 13. Historical type specimens of species of Plagigeyeria from Hercegovina and adjacent regions, currently transferred to the genus Travunijana Grego \& Glöer, 2019. A. Plagigeyeria robusta Schütt, 1959, Hercegovina, spring Čepelica near Bileća, holotype (SMF 162833). B. P. klemmi Schütt, 1961, Croatia, spring Stenjevac south of Vrgorac, holotype (SMF 164344). C. P. tribunicae Schütt, 1963, Hercegovina, spring Trebišnjica near Bileća, holotype (SMF 168968). D. P. edlaueri Schütt, 1961, Hercegovina, spring Sopot Mlin in Svitavsko Blato, holotype (SMF 164342). E. P. angelovi Schütt, 1972, Croatia, spring Ombla (Rijeka Dubrovačka) in Komolac, holotype (SMF 221242). F. P. nitida Schütt, 1963, Hercegovina, spring Sopot Mlin in Svitavsko Blato, holotype (SMF 168970). 


\section{Genus Travunijana Grego \& Glöer, 2019}

Until now, this recently described genus was recognised only from the type locality of its type species (Vrelo "Goricki Studenac" in Gorica near Trebinje). However, closer investigation of the protoconch structure as well as of the general shell morphology supported the transferral of several species formerly assigned to Plagigeyeria to the genus Travunijana.

\section{Differential diagnosis}

The genus Travunijana can be clearly distinguished from the genus Plagigeyeria by its overall pitted surface sculpture of the protoconch without any spiral cords. Plagigeyeria has a faintly malleated and radially structured protoconch with spiral cords, malleated or granulated inter-rib spaces without a pitted surface. Furthermore, the shells of Travunijana are more solid with no flaring and less expanded apertures and with straight lateral labral profile and a characteristic smooth sinuation at the columellar margin. The lateral labral profile of Plagigeyeria is mostly sinuated, especially around the anterior and posterior canals and the part of the columellar margin adjacent to columella is straight or weakly sinuated. The peristome of Plagigeyeria is more reflexed and more widely expanded. The shell surface of Travunijana is lacking the inter-rib axially malleated surface structures of Plagigeyeria. The genus Belgrandia Bourguignat, 1870 with its Balkan representatives has also a pitted protoconch, however the present pitting is deeper and coarser than that of Travunijana. The genus Belgrandia can be distinguished by a distinct callous varix at the labrum or at the labral part of the body whorl.

\section{Anatomy}

The anatomy of the male genitals of the type species is described by Grego \& Glöer (2019) (p. 88: fig. 6).

\section{Distribution}

The genus Travunijana is known from the karst regions adjacent to the South Dalmatian coastline from Gradac and Ploče to Dubrovnik, and about $32 \mathrm{~km}$ inland from the Adriatic coastline to Prolog, Vrgorac, Svitava, Veličani and to Trebinje. Further northwards its distribution is known from Trebinje to Bileća and towards Gatačko Polje and Dabarsko Polje to Vrelo "Bunica" in Hodbina (Fig. 19). The distribution ranges of Travunijana and Plagigeyeria overlap only in the area of Hodbina, Dabarsko Polje and north of Trebinje, where both genera could occur sympatrically.

\section{Type species}

Travunijana vruljakensis Grego \& Glöer, 2019, holotype HNHM MOLL 104416.

\section{Other taxa assigned to the genus}

Plagigeyeria ovalis Kuščer, 1933, Plagigeyeria robusta Schütt, 1959, Plagigeyeria robusta asculpta Schütt, 1972, Plagigeyeria klemmi Schütt, 1961, Plagigeyeria nitida Schütt, 1963, Plagigeyeria angelovi Schütt, 1972, Plagigeyeria edlaueri Schütt, 1961, Plagigeyeria tribunicae Schütt, 1963 and Travunijana gloeri sp. nov.

\section{Travunijana vruljakensis Grego \& Glöer, 2019}

Figs 5B, 14A

Travunijana vruljakensis Grego \& Glöer, 2019: 88, figs 2-6.

\section{Diagnosis}

Robust elongate-conical shell $(2.7-2.9 \mathrm{~mm})$ with prominent body whorl, fine axial growth lines, blunt apex, closed umbilicus, unprotruding aperture with straight labral profile and sinuated columellar 
aperture margin. Penis morphology characterised by a small typical outgrowth at the left side, near the blunt penis tip. Teleoconch surface with irregular growth lines, nepionic whorl with irregular flatnodulous malleation and protoconch surface weakly regularly pitted.

\section{Distribution}

The species is known only from its type locality at Vrelo "Goricki Studenac" at Gorica near Trebinje and in the nearby Vrelo "Vruljak 1".

\section{Remarks}

The type species of the genus can be classified as crenobiont, however the white animal and reduced eyes could suggest an adaptation to deeper crenobiont zone at the border of stygobiont habitat. The species was not found inside the deep cave zone of the adjacent cave Vrelo "Vruljak 1". The sexual dimorphism reported for this species (Grego \& Glöer 2019) can be very likely generalised to the whole genus and could explain the shell morphology variability of other species assigned herein to the genus.

Travunijana nitida (Schütt, 1963) comb. nov.

Fig. $13 \mathrm{~F}$

Plagigeyeria nitida Schütt, 1963: 210-211, fig. 8.

Plagigeyeria nitida - Schütt 1972: 116, 119, pl. 6 fig. 8. - Bole \& Velkovrh 1986: 202 - Bodon, Manganelli \& Giusti 1996: 33, fig. 13. - Bank 2013: Fauna Europaea v. 2.6 - Bank \& Neubert 2017: 25.

\section{Diagnosis}

Elongate-oval hard-shelled species $(3.6 \mathrm{~mm})$ with smooth shiny shell surface and weak umbilical keel present close to the umbilicus. Elongate oval aperture obscuring the umbilicus and only slightly protruding at the basal view. Lateral labral profile is straight and columellar labrum possesses a weak fold.

\section{Distribution}

The empty shells are known only from springs at the southern end of Hutovo (Svitavsko) Blato (Vrelo "Sopot Mlin" and others at Sjekoše and Bajovci 2 m a.s.1.) (Schütt 1972). These springs receive their karst water from the main swallow holes of the River Trebišnjica at the end of Popovo Polje (227 m a.s.1.).

\section{Remarks}

The species is typical with its carinated umbilicus and elongated smooth shell surface. It is well separable from the sympatric T. edlaueri (Schütt, 1961), which has a larger, more conical shell with a more inflated aperture, but both still keeping the straight labral profile and weak sinulus at the columellar margin.

Travunijana angelovi (Schütt, 1972) comb. nov. Figs 13E, 14B

Plagigeyeria nitida angelovi Schütt, 1972: 116, 119, tab. 6, fig. 9.

Plagigeyeria angelovi - Bole \& Velkovrh 1986: 202 - Bodon, Manganelli \& Giusti 1996: 33, fig. 13. Plagigeyeria nitida angelovi - Bank 2013: Fauna Europaea v. 2.6 - Bank \& Neubert 2017: 25. 


\section{Diagnosis}

Hard shell $(3.3 \mathrm{~mm})$ with conical spire and broader body whorl and with distinct broad and blunt umbilical keel at lower part of the body whorl. Aperture irregularly broad lens shaped and more protruding at the basal view. Lateral labral profile straight and columellar labrum possesses a weak sinuation. Protoconch surface regularly pitted.

\section{Distribution}

Empty shells are known from the Vrelo "Ombla" (2.5 m a.s.1.) in Komolac near Dubrovnik (Schütt 1972; Schütt 2000), supplied by groundwater mainly from Popovo Polje (269 m a.s.1.) and its hinterland.

\section{Remarks}

The second carinated species of the Western Trebišnjica aquifer, T. angelovi (Schütt, 1972) has an elongate shape with a smooth surface. Originally placed by Schütt (1972) as a subspecies of T. nitida (Schütt, 1963), it is known from springs in Hutovo (Svitavsko) Blato. However nothing common can be found on the shell morphology of both taxa except for the carinated bottom of the body whorl; so their treatment as independent species is preferred herein. Travunijana angelovi can be scarcely found in the accessible thanatocoenoses of the Vrelo "Ombla" near Komolac. Only a few usually worn shells within each sample suggest that its remote habitat is most likely situated deep inside the mountain, far away from the spring outlet.

Travunijana tribunicae (Schütt, 1963) comb. nov.

Figs $13 \mathrm{C}, 14 \mathrm{C}-\mathrm{D}$

Plagigeyeria tribunicae Schütt, 1963: 208-209, figs 4-7.

Plagigeyeria tribunicae - Schütt 1972: 116, 123, pl. 8. figs 21-22. - Willmann \& Pieper 1978: 126 Bole \& Velkovrh 1986: 202 — Bodon, Manganelli \& Giusti 1996: 33, fig. 13. — Bank 2013. Fauna Europaea v. 2.6 - Bank \& Neubert 2017: 25

\section{Diagnosis}

Flat discoid shell 1.9-2.5 mm high with prominent body whorl having angled basal keel at its lower part and an ear-shaped aperture. Spire height variable, from entirely flat to elevated broad conical shape. Shell shape unique within the genera Travunijana and Plagigeyeria. Lateral labral profile straight and columellar labrum possesses a weak sinuation. Protoconch surface regularly and deeply pitted.

\section{Distribution}

Only known from the springs of Trebišnjica River (342 m a.s.1.) in Bileća (Schütt 1972), currently flooded under the lake behind the Grančarevo Dam (Bilećko Jezero). The Trebišnjica River springs represent a rather complicated hydrological drainage pattern. Most of the springs receive their water supplies from Gatačko Polje (936 m a.s.1.), Cerničko Polje (816 m a.s.l.) and partly through Fatničko Polje (452 m a.s.1.), but at least two of the springs, Vrelo "Oko" and Nikšićko Vrelo, collecting also the interim divergent groundwaters from Northern Nikšićko Polje (643 m a.s.l.).

\section{Remarks}

The distinct shells of T. tribunicae (Schütt, 1963) detected in the subsidiary spring of the Trebišnjica (Nikšićko Vrelo, $342 \mathrm{~m}$ a.s.l.), show a remarkable variability in spire height from flat to pyramidal form (Schütt 1972). Unfortunately the type locality is currently flooded by the Grančarevo Dam, and it is questionable whether the lake had altered the subterranean aquifer water streams in a negative way 


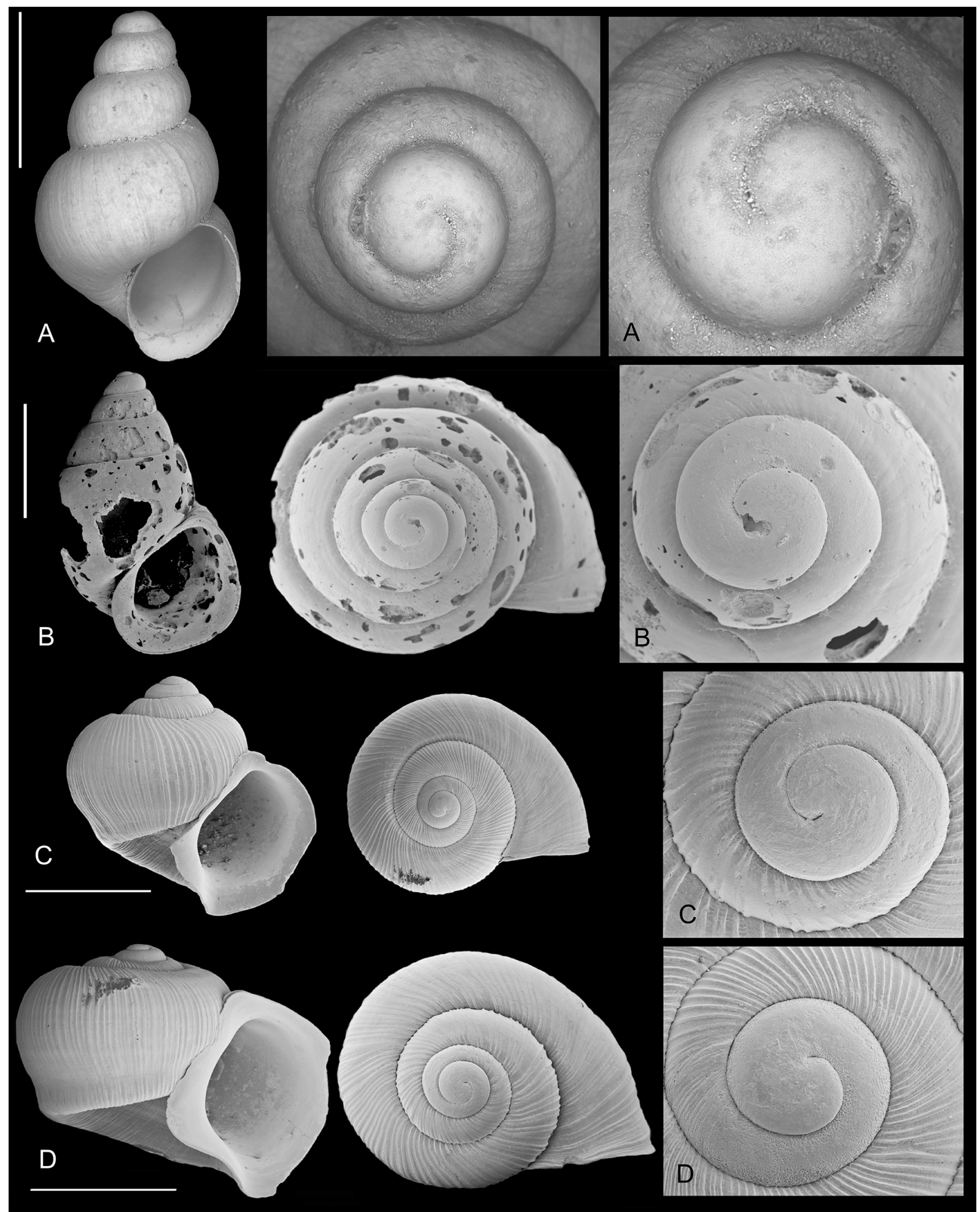

Fig. 14. A. Travunijana vruljakensis Grego \& Glöer, 2019, Hercegovina, Vrelo Studenac, Gorica near Trebinje, SBMNH 625961 (SEM SBMNH Vanessa Delnavaz). B. T. angelovi (Schütt, 1972), Spring Ombla, Komolac near Dubrovnik, paratype (SMF 318892). C-D. T. tribunicae (Schütt, 1963), Hercegovina, Bileća, main spring of Trebijšnica. C. SMF 191518. D. SMF 318909. Scale bars $=1 \mathrm{~mm}$ (B-D SEM SMF Sigrid Hof). 
leading to the species' extinction, or if the species might still have survived in some other part of the aquifer. The shell morphology with dominant body whorl and keeled umbilicus significantly resembles the Plagigeyeria sp. morphotypes found at the north-western edge of Nikšićko Polje (Montenegro, 643 $\mathrm{m}$ a.s.1.), confirming the transboundary communication of aquifers at least during high groundwater periods. However, the pitted protoconch structure is more similar to that of the genus Travunijana. The slightly reflexed margin is unique in the genus Travunijana and its position within this genus is only provisional. Based on the conditions of empty shells, the habitat is most likely upstream inside the undiscovered cave system, far from the actual spring water outlet (recently under the Bilećko Jezero) where the empty shells were collected.

Travunijana ovalis (Kuščer, 1933) comb. nov.

Fig. 7I-K

Plagiogeyeria (sic) ovalis Kuščer, 1933: 62-63, pl. 1, fig. 4.

Plagigeyeria ovalis - Jaeckel, Klemm \& Meise 1957: 174. — Jaeckel 1967: 92. — Bole \& Velkovrh 1986: 202.

Plagigeyeria mostarensis ovalis - Bank 2013: Fauna Europaea v. 2.6 — Bank \& Neubert 2017: 25.

non Plagigeyeria mostarensis ovalis - Schütt 1972: 119, tab. 6, fig. 4.

\section{Diagnosis}

Robust oval shell $(3 \mathrm{~mm})$ with prominent body whorl and conical spire, smooth or finely striated shell surface, blunt apex, narrow umbilicus and large callous irregularly oval aperture only slightly protruding at basal view. Lateral labral profile straight and columellar labrum possesses a weak-cut sinuation. Protoconch very faintly pitted.

\section{Distribution}

Known only from Vrelo "Bunica" (55 m a.s.1.) near Hodbina south of Mostar. The records of the species from springs at lower Neretva (Kuščer 1935) were not supported since and need further confirmation.

\section{Remarks}

Kuščer (1933) described Plagiogeyeria (sic) ovalis as a subspecies of P. mostarensis with the type locality in the Buna spring. However, many sampling attempts in the type locality (Vrelo "Buna") have not proven the presence of the species. The species was repeatedly detected in the sediments of the Vrelo "Bunica", a name very similar to the one given as the type locality. We suppose the true type locality of $P$. ovalis is the Vrelo "Bunica", and the original labels were likely misinterpreted in same manner as for $P$. mostarensis described from the same collection at the same time from the same locality. The subspecific status of $P$. ovalis was misleading for most of the following authors as Schütt (1972), figured a specimen of $P$. mostarensis from Vrelo "Buna" with a less elevated and broken spire as $P$. mostarensis ovalis (p. 119, pl. 6, fig. 4.). The understanding of $P$. ovalis as a valid species was therefore overlooked for several decades. Nevertheless, $P$. ovalis can be clearly distinguished from $P$. mostarensis not only by its more robust-oval shell with different aperture shape, but also by its less conspicuous ribbing, representing rather axial growth lines, and by a substantially different straight lateral and weakly sinuated columellar marginal profile, against the strongly sinuated ones in P. mostarensis. Furthermore, the substantially different protoconch morphology separate both taxa also on the genus level. 
Travunijana robusta robusta (Schütt, 1959) comb. nov.

Figs $7 \mathrm{~L}-\mathrm{M}, 13 \mathrm{~A}, 15 \mathrm{~A}-\mathrm{B}$

Plagigeyeria robusta Schütt, 1959: 186, fig. 1.

Plagigeyeria robusta - Schütt 1972: 115, 123, pl. 8 figs 23-24. — Willmann \& Pieper 1978: 126. Bole \& Velkovrh 1986: 202. — Bodon, Manganelli \& Giusti 1996: 33, fig. 13. — Bank 2013: Fauna Europaea v. 2.6 - Bank \& Neubert 2017: 25.

\section{Diagnosis}

Robust oval-conical shell $(2.1 \mathrm{~mm})$ with thick walls, rounded apex, smooth or finely ribbed shell surface, elongate round-rhomboidal aperture with slightly protruded columellar fold, open umbilicus and not protruded aperture against basal shell profile. Lateral labral profile straight and columellar labrum possesses weak negative sinuation. Nepionic whorl with weakly cancellated surface and protoconch with distinct pitting. Pitting depth variable according to population: Vrelo "Vruljak 1" population with regular shallow pitting concentrating around the suture and very weak at central part of whorl; population from Vrelo "Tučevac" with overall regular deep pitting over the whole protoconch surface.

\section{Distribution}

Travunijana robusta is known from the spring group of Trebišnjica near Bileća and Vrelo Čepo near Čepelica (currently flooded by the Bilećko Jezero), and from Estavela "Obod" in Fatničko Polje (452 m a.s.1.), spring Dobričevo near Stepen in Gatacko Polje (936 m a.s.1.) (Schütt 1972), and from Vrelo "Goricki Studenac" (280 m a.s.1.), Vrelo "Vruljak 1" (282 m a.s.1.) and Vrelo "Tučevac" (275 m. a.s.l.) in Trebinje.

\section{Remarks}

Most of the robust Travunijana specimens found in the Trebišnjica River Basin are assigned to Travunijana robusta (Schütt, 1959) (Fig. 7L-M) divided into two populations or maybe subspecies (Schütt 1972). The karst conduits north of the Trebišnjica valley (north of Popovo Polje) host the nominotypical subspecies. The karst conduits south of Popovo and Mokro Poljes are populated by T. robusta asculpta (Schütt, 1972) (Fig. 7N). Furthermore, each particular locality can have specific morphotypes (e.g., population in Vrelo "Tučevac" near Trebinje hosts its specific smooth-shelled morphotype with different aperture), which are for time being regarded as falling within one morphologically variable species.

Travunijana robusta asculpta (Schütt, 1972) comb. nov.

Figs $7 \mathrm{~N}, 15 \mathrm{C}$

Plagigeyeria robusta asculpta Schütt, 1972: 115, 122, pl. 8, figs 25-26.

Plagigeyeria robusta asculpta - Bole \& Velkovrh 1986: 202. — Bank 2013: Fauna Europaea v. 2.6. — Bank \& Neubert 2017: 25.

\section{Diagnosis}

Shell very similar to nominotypical subspecies but having in general a more elevated, more conical spire with blunter apex. Surface can be smooth or finely ribbed as well as in the nominotypical morphotype. Aperture ear-shaped and missing the slightly protruded columellar fold of the nominotypical subspecies. Lateral labral profile straight and columellar labrum possesses a weak cut sinuation. Protoconch surface pitted. 


\section{Distribution}

Travunijana robusta asculpta can be found in the thanatocoenoses of the Vrelo "Ombla" near Komolac (7 m a.s.1.) and Vrelo "Mlin" (2 m a.s.l.) at Mali Zaton north of Dubrovnik. Springs are draining the karst area of upper-to-central Popovo Polje (227 m a.s.l).

\section{Remarks}

The morphological variability of nominotypical subspecies and $T$. robusta asculpta overlap significantly and even Schütt (2000) assigned some of specimens of P. robusta asculpta from the type locality (Vrelo "Ombla") to the nominotypical subspecies based upon the presence of ribs, and conversely, the few specimens collected from Trebišnjica Springs in Bileća were assigned to T. robusta asculpta just for their lack of ribs. However the presence or absence of the fine shell ribs on the eroded shells found in the thanatocoenoses has to be carefully evaluated by their remains around the suture, as upon first sight both ribbed and smooth forms can be found in the thanatocoenoses within the springs draining the whole Eastern Trebišnjica aquifer. The main distinguishing feature of T. robusta asculpta is in general the more elevated and more conical spire and slightly more elongated shell shape, but even this feature possesses a high variability within each locality. Until live material becomes available and larger shells material can be examined, I prefer to separate both in a provisional way on a subspecies level, based only on their zoogeographical data. It is possible that further investigation could reveal several related species in the T. robusta complex.

Travunijana klemmi (Schütt, 1961) comb. nov.

Figs 13B, 16A-B

Plagigeyeria klemmi Schütt, 1961: 133-134, fig. 2.

Plagigeyeria klemmi - Schütt 1972: 115, 119 pl. 6 figs 5-6. — Willmann \& Pieper 1978: 126. Bole \& Velkovrh 1986: 202. — Bodon, Manganelli \& Giusti 1996: 33, fig. 13. — Bank 2013: Fauna Europaea v. 2.6. — Bank \& Neubert 2017: 25.

\section{Diagnosis}

T. klemmi has regularly narrow-conical shells $(2.2 \mathrm{~mm})$ with blunt apex, deep suture and widely spaced coarse ribs on shell surface, rounded callous irregular-oval shaped aperture and closed umbilicus. Lateral labral profile straight and columellar labrum only weakly sinuated. Protoconch surface overall covered by regular and deep pitting.

\section{Distribution}

T. klemmi is known from Vrelo "Stenjevac" and Vrelo "Baja" in Vrgorsko Polje (20 m a.s.1.) near Vrgorac and from Vrelo "Kutac" and other springs around Baćinska Lakes (0.8 m a.s.1.) near Ploče. The aquifer also receives its water from Rastok Polje (72 m a.s.1.).

\section{Remarks}

Travunijana klemmi represents the northernmost species of the genus. Its shell morphology has some features of the genus Belgrandia (e.g., Belgrandia torifera Schütt, 1961) known from the region, however its shell is more conical and lacks the typical callous varix near the labrum.

Travunijana edlaueri (Schütt, 1961) comb. nov.

Figs 13D, 16C-D

Plagigeyeria edlaueri Schütt, 1961:132-133, fig. 1. 

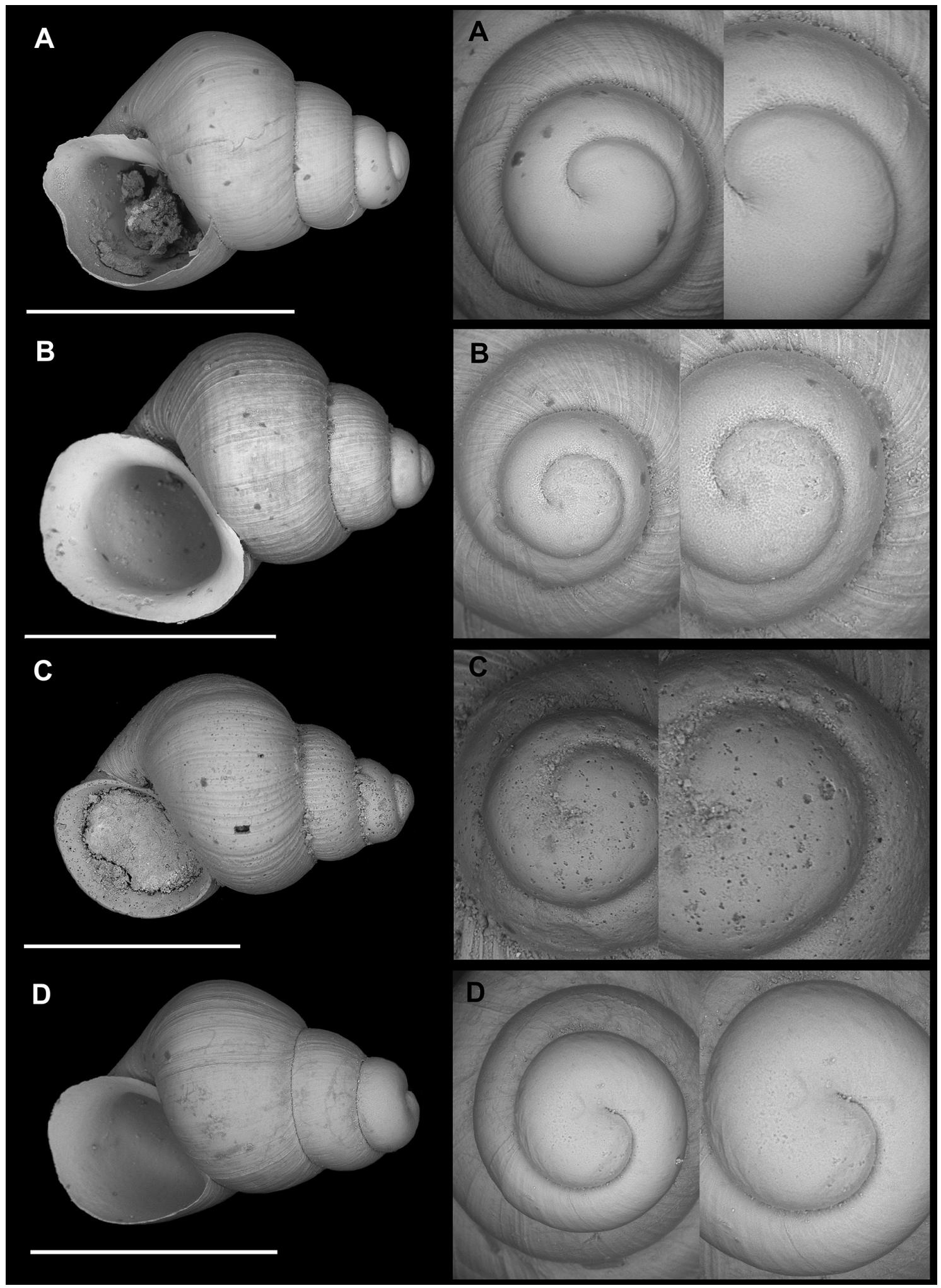

Fig. 15. A. Travunijana robusta (Schütt, 1959), Trebinje, Izvor Tučevac, SBMNH 626406. B. Travunijana robusta (Schütt, 1959), Trebinje, Vrelo Vruljak 1, SBMNH 625919. C. Travunijana robusta asculpta (Schütt, 1972), Croatia, Dubrovnik, Komolac, Izvor Ombla, SBMNH 625896. D. Travunijana gloeri sp. nov., Bjeljani, Dabarsko Polje, Vrelo Vrijeka, paratype SBMNH 632722. Scale bars $=1 \mathrm{~mm}$. (SEM SBMNH Vanessa Delnavaz). 
Plagigeyeria edlaueri - Schütt 1972: 115, 119, pl. 6 fig. 7. - Willmann \& Pieper 1978: 126. — Bole \& Velkovrh 1986: 202. — Bodon, Manganelli \& Giusti 1996: 33, fig. 13. — Bank 2013: Fauna Europaea v. 2.6. — Bank \& Neubert 2017: 24.

\section{Diagnosis}

Shell large for the genus $(3.7 \mathrm{~mm})$, conical spire with regularly tapering whorls, weak suture and rather sharp apex, body whorl triangular, centrally bumped, shell surface smooth shiny, aperture wide, callous, but not expanded and conspicuously protruding at the labral view. Lateral labral profile is straight and columellar labrum possesses a weak negative sinuation at the slightly protruding columellar fold. Protoconch surface overall covered by regular, large and very deep pitting.

\section{Distribution}

Empty eroded shells of T. edlaueri appear in the sediment of springs at the side of the Hutovo (Svitavsko) Blato depression (2 m a.s.1.) (Vrelo "Sopot Mlin" and at Sjekoše) and in Vrelo "Glušči" (4 m a.s.l.) near Metković in Croatia. The springs are draining karst water from main swallow holes of the River Trebišnjica at the end of Popovo Polje (227 m a.s.1.) and from Gradac Polje (88 m a.s.1.), and are connected to the alluvial delta of the Neretva River.

\section{Remarks}

Travunijana edlaueri is one of the largest representatives of the genus, frequently reaching over $3 \mathrm{~mm}$ (max. $3.7 \mathrm{~mm}$ ). Its general shell shape is most similar to Plagigeyeria of all the species of Travunijana, however the pitted protoconch structure and straight labral / weakly sinuated columellar labrum indicates its position within the genus Travunijana or maybe within a new unrecognized genus.

Travunijana gloeri sp. nov. urn:lsid:zoobank.org:act:2A411831-BA56-490B-8754-80A0A0EE048F

Figs 9K-L,15D

\section{Type material}

\section{Holotype}

BOSNIA AND HERCEGOVINA • 1 shell; Republika Srpska, Bileća Municipality, Berkovići, Vrelo "Vrijeka" in Dabarsko Polje NW of Bjeljani (Fig. 3A); 4304'28.9" N, 18¹4'20.6" E; 498 m a.s.l.; 22 Apr. 2019; J. Grego, G. Jakab, M. Olšavský and M. Kováčiková leg.; HNHM-MOLL-104418/1.

\section{Paratypes}

BOSNIA AND HERCEGOVINA • 10 shells; same data; HNHM-MOLL-104419/1, SBMNH 632722/1, coll. Grego/8, coll. Glöer/1 • 2 shells; same locality as for holotype; D. Angyal, J. Grego, G. Jakab and M. Olšavský leg.; coll. Grego/2.

\section{Other material}

BOSNIA AND HERCEGOVINA • 6 shells; Republika Srpska, Bileća Municipality, Orahovice, Estavela "Obod" in Fatničko Polje; leg. 22 Apr. 2019; J. Grego, G. Jakab, M. Olšavský and M. Kováčiková; $43.018543^{\circ} \mathrm{N}, 18.348643^{\circ} \mathrm{E}$; coll. Grego/9.

\section{Dimensions}

Holotype: H 3.38 mm; W 1.96 mm; BH 2.23 mm; BW 1.56 mm; AH 1.51 mm; AW 1.29 mm.

Paratype: H 3.38 mm; W 1,87 mm; BH 2.31 mm; BW 1.60 mm; AH 1.42 mm; AW 1.24 mm. 


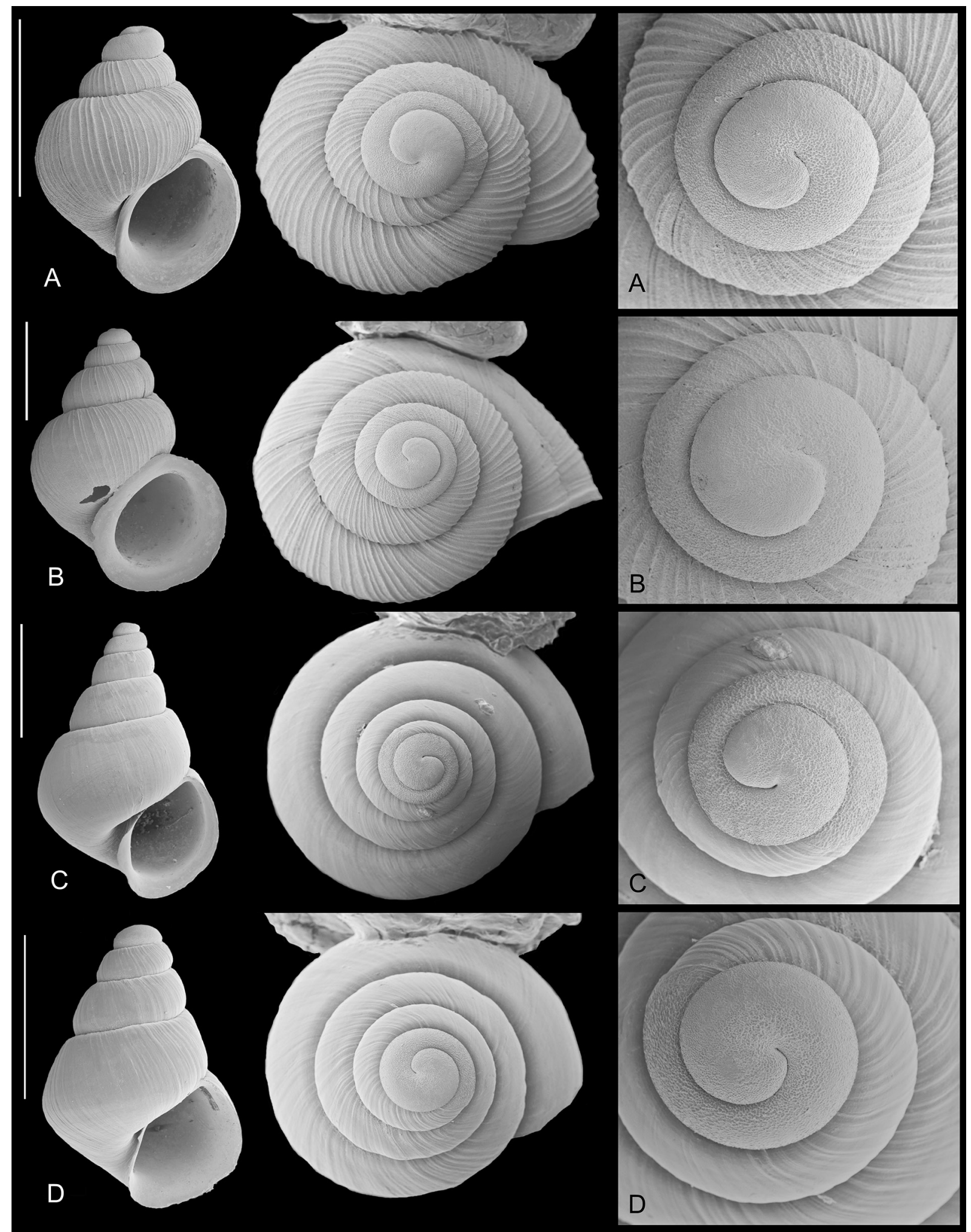

Fig. 16. A-B. Travunijana klemmi (Schütt, 1961), Croatia, spring in Stenjevac near Vrgorac. A. SMF 318873. B. Paratype SMF 164345. C. T. edlaueri (Schütt, 1961), Hercegovina, Sopot Mlin at south bank of Svitavsko Blato near Metkovic, SMF 171671. D. T. edlaueri, Hercegovina, Sjekoše at south bank of Svitavsko Blato near Metkovic, SMF 318858. Scale bars $=1 \mathrm{~mm}$ (SEM SMF Sigrid Hof). 


\section{Etymology}

Named after my friend and renowned malacologist Peter Glöer from Hetlingen, Germany, who largely contributed to the freshwater gastropod fauna of the Balkans.

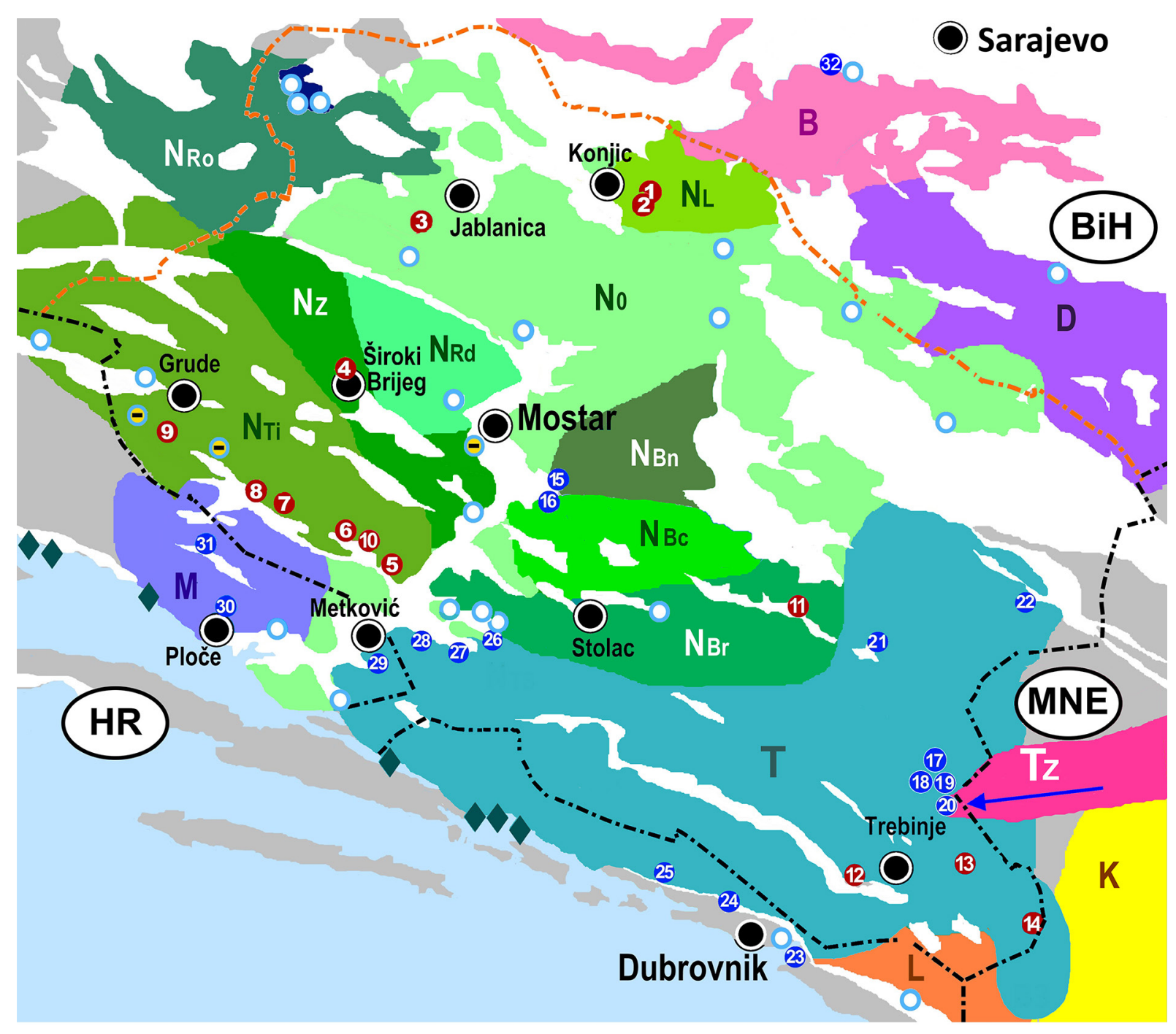

Fig. 17. Karst aquifers of Hercegovina and their estimated delimitations to drainage basins. As most to the karst aquifers in Hercegovina are represented by subterranean karst conduits, it is difficult to exactly set the watersheds. The subterranean drainage divides in this map were estimated based on our recent knowledge about the geology, hydrogeology and geomorphology. The boundaries are unstable and strongly dependent on a dynamic system of particular water level alternations in each perched water table within the basin as well as on their particular saturation. The interim oversaturation in the particular basin could lead to water divergence to the neighbouring river basin. The supposed inter-basin water divergences at high water saturation are highlighted by blue arrows. Each drainage basin could be further divided to separate subterranean karst conduits, which could also represent a kind of particularly isolated habitat. Freshwater springs are in circles and brackish or submarine spring are as diamonds with locality numbers according to the legend from Figure 1. 


\section{Description}

Inflated conical $3.38 \mathrm{~mm}$-high shell with dominant convex body whorl. Light yellowish corneous shell with smooth shiny surface, weak close-set axial ribs and 4.5 convex whorls separated by a weak suture. Protoconch surface smooth, weakly and distantly pitted with larger weak malleation over the pitting. Apex blunt and flat. Umbilicus closed. Elongate asymmetric-oval aperture attached to the body whorl by a weak sulcus. Peristome callous and blunt, not reflexed. Outer lip almost flat at and weakly sinuated at columellar profile. Aperture profile aligned with the body whorl and with the evenly tapering whorls at basal view.

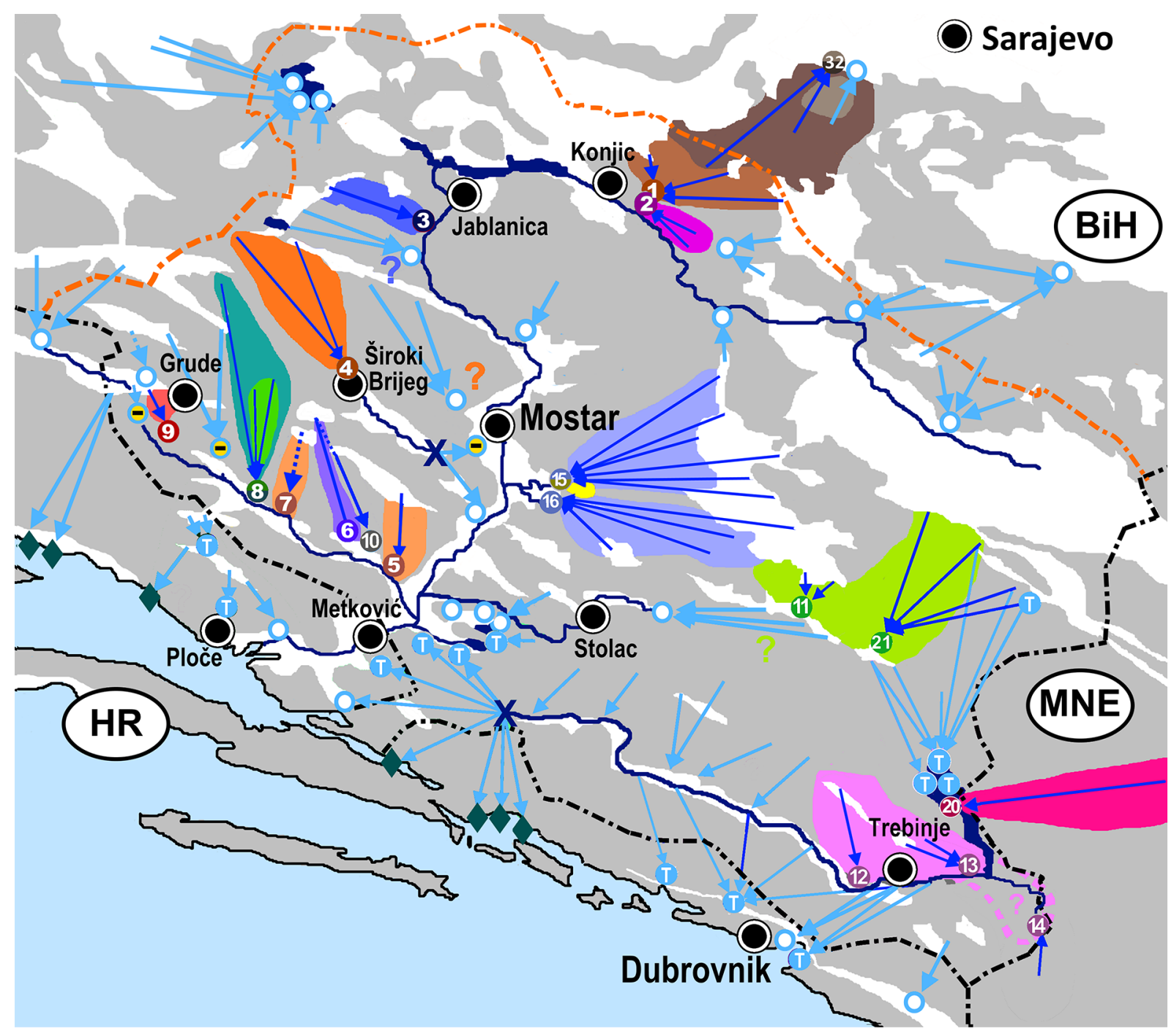

Fig. 18. Localities of Plagigeyeria species in Hercegovina and adjacent regions and the most likely distribution range of the known species within the related aquifers (colour blotches) and sampling localities (dots with numbers). Freshwater springs are in circles and brackish or submarine springs are as marked by diamonds, arrows show main karst conduits and locality numbers are according to the legend from Fig. 1. 


\section{Differentiating features}

The shells of T. gloeri sp. nov. differ from T. ovalis (Fig. 7I-K) from spring of Bunica River near Hodbina (but not found in Vrelo "Buna" as declared by Kuščer (1933) as its type locality) by its more slender shell shape, closed umbilicus and more flat protoconch. From the type species T. vruljakensis it differs by adapically more protruded and differently shaped aperture, by more coarsely ribbed teleoconch surface and by more smooth protoconch surface. Shell morphometry comparison with the related Travunijana species is presented in the Table 4.

\section{Habitat}

See habitat of $P$. reischuetzorum sp. nov.

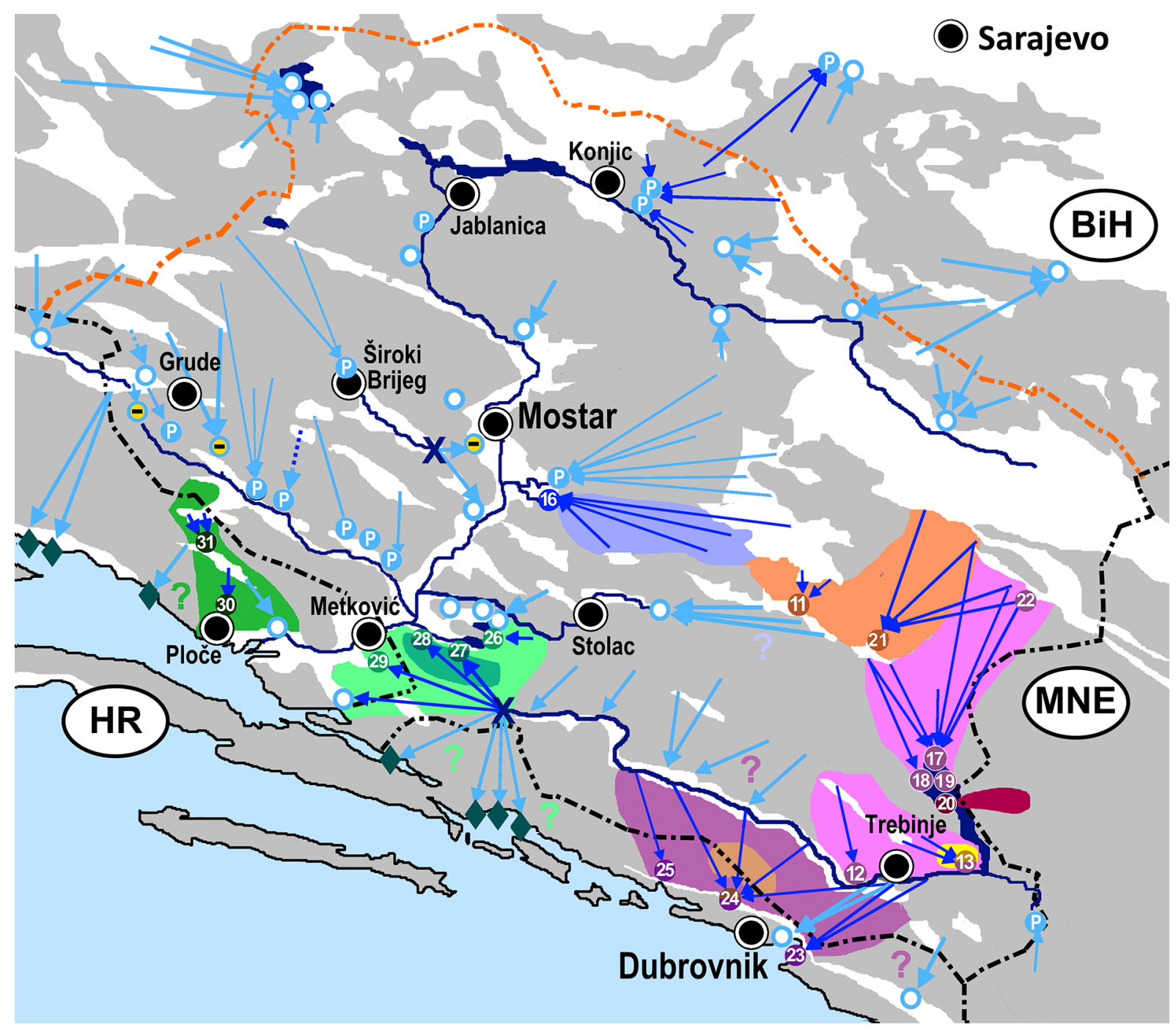

Fig. 19. Localities of species of Travunijana in Hercegovina and adjacent regions and the most likely distribution range of the known species within the related aquifers (colour blotches) and sampling localities (dots with numbers). Freshwater springs are in circles and brackish or submarine springs are as marked by diamonds, arrows show main karst conduits and locality numbers are according to the legend from Fig. 1. 
Table 4. Shell morphometry comparison of species of Travunijana Grego \& Glöer, 2019.

\begin{tabular}{|c|c|c|c|c|c|c|c|c|c|c|c|c|c|c|c|}
\hline \multirow[t]{2}{*}{ Species } & \multirow[t]{2}{*}{ Specimen } & & \multirow{2}{*}{$\begin{array}{l}\mathbf{W} \\
\mathrm{mm}\end{array}$} & \multirow{2}{*}{$\begin{array}{l}\mathbf{B H} \\
\mathrm{mm}\end{array}$} & \multirow{2}{*}{$\begin{array}{l}\mathbf{B W} \\
\mathrm{mm}\end{array}$} & \multirow{2}{*}{$\begin{array}{l}\mathbf{A H} \\
\mathrm{mm}\end{array}$} & \multirow{2}{*}{$\begin{array}{l}\mathbf{A W} \\
\mathrm{mm}\end{array}$} & \multirow{2}{*}{$\begin{array}{l}\mathbf{C A} \\
\mathrm{mm}\end{array}$} & \multirow{2}{*}{$\begin{array}{l}\mathbf{H} / \mathbf{W} \\
\circ\end{array}$} & \multirow{2}{*}{$\begin{array}{l}\mathbf{A H} \\
/ \\
\mathbf{A W}\end{array}$} & \multirow{2}{*}{$\begin{array}{l}\mathbf{W} / \\
\text { BW }\end{array}$} & \multirow{2}{*}{$\begin{array}{l}\mathbf{H} / \\
\mathbf{B H}\end{array}$} & \multirow{2}{*}{$\begin{array}{l}\mathbf{H} / \\
\mathbf{A H}\end{array}$} & \multirow{2}{*}{$\begin{array}{l}\mathbf{W} / \\
\mathbf{A W}\end{array}$} & \multirow{2}{*}{$\begin{array}{l}\text { H/ } \\
(\mathbf{W}- \\
\text { BW) }\end{array}$} \\
\hline & & & & & & & & & & & & & & & \\
\hline $\begin{array}{l}\text { Travunijana } \\
\text { ovalis }\end{array}$ & $\begin{array}{l}\text { Topotype } \\
\text { JG F1145/1 }\end{array}$ & 2,38 & 1,48 & 1,48 & 1,10 & 1,34 & 1,08 & 30 & 1,61 & 1,24 & 1,00 & 1,61 & 1,78 & 1,37 & 6,26 \\
\hline $\begin{array}{l}\text { Travunijana } \\
\text { ovalis }\end{array}$ & $\begin{array}{l}\text { Topotype } \\
\text { JG F1145/2 }\end{array}$ & 2,79 & 1,96 & 2,17 & 1,48 & 1,51 & 1,31 & 32 & 1,42 & 1,15 & 0,90 & 1,29 & 1,85 & 1,50 & 5,81 \\
\hline $\begin{array}{l}\text { Travunijana } \\
\text { ovalis }\end{array}$ & $\begin{array}{l}\text { Holotype } \\
\text { from Kuščer } \\
1933\end{array}$ & 2,59 & 1,59 & 1,89 & 1,34 & 1,28 & 0,97 & 30 & 1,63 & 1,32 & 0,84 & 1,37 & 2,02 & 1,64 & 10,36 \\
\hline $\begin{array}{l}\text { Travunijana } \\
\text { robusta }\end{array}$ & $\begin{array}{l}\text { Hypotype } \\
\text { SMF } 162833\end{array}$ & 1,97 & 1,54 & 1,49 & 1,23 & 1,08 & 0,91 & 30 & 1,28 & 1,19 & 1,25 & 1,32 & 1,82 & 1,69 & 6,35 \\
\hline $\begin{array}{l}\text { Travunijana } \\
\text { var. robusta }\end{array}$ & $\begin{array}{l}\text { Tučevac, } \\
\text { JG F1192 }\end{array}$ & 2,38 & 1,59 & 1,69 & 1,34 & 1,24 & 1,38 & 40 & 1,50 & 0,90 & 0,94 & 1,41 & 1,92 & 1,15 & 9,52 \\
\hline $\begin{array}{l}\text { Travunijana } \\
\text { var. robusta }\end{array}$ & $\begin{array}{l}\text { Vruljak } \\
\text { JG F0831 }\end{array}$ & 1,93 & 1,41 & 1,07 & 1,17 & 1,03 & 0,86 & 39 & 1,37 & 1,20 & 1,32 & 1,80 & 1,87 & 1,64 & 8,04 \\
\hline $\begin{array}{l}\text { Travunijana } \\
\text { robusta } \\
\text { asculpta }\end{array}$ & $\begin{array}{l}\text { Topotype } \\
\text { JG F1209 }\end{array}$ & 2,41 & 1,72 & 1,21 & 1,37 & 1,24 & 1,10 & 35 & 1,40 & 1,13 & 1,42 & 1,99 & 1,94 & 1,56 & 6,89 \\
\hline $\begin{array}{l}\text { Travunijana } \\
\text { gloeri } \\
\text { sp. nov. }\end{array}$ & $\begin{array}{l}\text { Holotype } \\
\text { HNHM } \\
104180\end{array}$ & 3,38 & 1,96 & 2,23 & 1,56 & 1,51 & 1,29 & 30 & 1,73 & 1,17 & 1,26 & 1,51 & 2,24 & 1,52 & 8,44 \\
\hline $\begin{array}{l}\text { Travunijana } \\
\text { gloeri } \\
\text { sp. nov. }\end{array}$ & $\begin{array}{l}\text { Paratype } \\
\text { JG F1117/1 }\end{array}$ & 3,38 & 1,87 & 2,31 & 1,60 & 1,42 & 1,24 & 30 & 1,81 & 1,14 & 1,17 & 1,46 & 2,38 & 1,50 & 12,67 \\
\hline $\begin{array}{l}\text { Travunijana } \\
\text { gloeri } \\
\text { sp. nov. }\end{array}$ & $\begin{array}{l}\text { Paratype } \\
\text { JG F1117/2 }\end{array}$ & 2,88 & 1,60 & 2,07 & 1,39 & 1,26 & 1,07 & 31 & 1,80 & 1,18 & 0,77 & 1,39 & 2,29 & 1,50 & 13,71 \\
\hline $\begin{array}{l}\text { Travunijana } \\
\text { gloeri } \\
\text { sp. nov. }\end{array}$ & $\begin{array}{l}\text { Paratype } \\
\text { JG F1117/3 }\end{array}$ & 2,90 & 1,52 & 2,09 & 1,36 & 1,36 & 1,12 & 32 & 1,91 & 1,21 & 0,73 & 1,39 & 2,13 & 1,36 & 18,13 \\
\hline $\begin{array}{l}\text { Travunijana } \\
\text { vruljakenis }\end{array}$ & $\begin{array}{l}\text { Paratype } \\
\text { HNHM } \\
104416\end{array}$ & 2,95 & 1,65 & 2,05 & 1,50 & 1,15 & 1,10 & 39 & 1,79 & 1,05 & 1,10 & 1,44 & 2,57 & 1,50 & 19,67 \\
\hline $\begin{array}{l}\text { Travunijana } \\
\text { vruljakensis }\end{array}$ & $\begin{array}{l}\text { Paratype } \\
\text { JG F1173 }\end{array}$ & 2,85 & 1,50 & 1,95 & 1,40 & 1,20 & 1,00 & 36 & 1,90 & 1,20 & 1,07 & 1,46 & 2,38 & 1,50 & 28,50 \\
\hline $\begin{array}{l}\text { Travunijana } \\
\text { vruljakensis }\end{array}$ & $\begin{array}{l}\text { Paratype } \\
\text { coll. Glöer }\end{array}$ & 2,83 & 1,75 & 1,95 & 1,50 & 1,25 & 1,05 & 34 & 1,62 & 1,19 & 1,17 & 1,45 & 2,26 & 1,67 & 11,32 \\
\hline $\begin{array}{l}\text { Travunijana } \\
\text { vruljakensis }\end{array}$ & $\begin{array}{l}\text { Paratype } \\
\text { coll. Glöer }\end{array}$ & 2,63 & 1,40 & 1,93 & 1,20 & 1,10 & 0,85 & 34 & 1,88 & 1,29 & 1,17 & 1,36 & 2,39 & 1,65 & 13,15 \\
\hline $\begin{array}{l}\text { Travunijana } \\
\text { tribunicae }\end{array}$ & $\begin{array}{l}\text { Paratype } \\
\text { SMF } 168968\end{array}$ & 1,94 & 2,43 & 1,74 & 1,57 & 1,57 & 1,34 & 22 & 0,80 & 1,17 & 1,40 & 1,11 & 1,24 & 1,81 & 2,26 \\
\hline $\begin{array}{l}\text { Travunijana } \\
\text { edlaueri }\end{array}$ & $\begin{array}{l}\text { Paratype } \\
\text { SMF } 164342\end{array}$ & 3,45 & 2,66 & 2,29 & 1,77 & 1,85 & 1,80 & 36 & 1,30 & 1,03 & 1,16 & 1,51 & 1,86 & 1,48 & 3,88 \\
\hline $\begin{array}{l}\text { Travunijana } \\
\text { nitida }\end{array}$ & $\begin{array}{l}\text { Paratype } \\
\text { SMF } 168970\end{array}$ & 3,05 & 1,91 & 2,08 & 1,43 & 1,48 & 1,20 & 28 & 1,60 & 1,23 & 0,92 & 1,47 & 2,06 & 1,59 & 6,35 \\
\hline $\begin{array}{l}\text { Travunijana } \\
\text { klemmi }\end{array}$ & $\begin{array}{l}\text { Paratype } \\
\text { SMF } 164344\end{array}$ & 2,05 & 1,37 & 1,37 & 1,00 & 1,00 & 0,97 & 42 & 1,50 & 1,03 & 1,37 & 1,50 & 2,05 & 1,41 & 5,54 \\
\hline $\begin{array}{l}\text { Travunijana } \\
\text { angelovi }\end{array}$ & $\begin{array}{l}\text { Paratype } \\
\text { SMF } 221242\end{array}$ & 3,34 & 1,77 & 2,09 & 1,43 & 1,34 & 1,14 & 28 & 1,89 & 1,18 & 0,85 & 1,60 & 2,49 & 1,55 & 9,82 \\
\hline
\end{tabular}




\section{Distribution}

The new species is known only from the type locality.

\section{Discussion}

The shell shape with solid expanded labrum, characteristic for the genus Plagigeyeria, suggests a strong adaptation to open phreatic cave aquifers with at least periodically extremely high water flow velocities. The trumpet-like expanded aperture helps to increase the adhesion and suction surface of the gastropod foot (similar to limpets) and the presence of ribbing could mechanically strengthen the shell in the harsh water conditions and reduce its abrasion. Occasional rich thanatocoenoses of fragments and empty shells at the spring outlets without any live specimens (even an absence of live juveniles) and very scarce fresh specimens, indicates a specific habitat inside the phreatic cave passages and karst conduits with open spaces, mostly located far from the spring zone and with a higher water stream velocity. Once the specimens are detached from the cave walls and rocks by the underground stream, they are usually washed away out of the cave where they then die. By the time empty shells reach the surface through the spring zone, most are eroded or fragmented, frequently deposited deeply inside the spring sediment. The species of Plagigeyeria have already adapted their shell morphology to the open cave habitat and the populations have also lost their capability to communicate through the tiny interstitial channels of the alluvial gravel sediments. The shell shape is not suitable for movement inside the gravel interstitial (as the shells adapted by genera Paladilhiopsis Pavlović, 1913 and Iglica A. J. Wagner, 1910) and it is highly unlikely that the species of Plagigeyeria could be dispersed between aquifers via the alluvial aquifers. Maybe under special circumstances the juvenile specimens could manage some shorter transfer through the interstitial. The open cave aquifer habitat preference is the main reason for the separation and fragmentation of different Plagigeyeria populations and it is likely that each isolated karst conduit hosts its own, very seldom two, Plagigeyeria species, maybe subspecies or at least a morphotype in some areas sympatric with one or two species of Travunijana. The isolated populations could mutually communicate only through occasional bypass water cross-connections (divergence) among aquifers during sporadically occurring high-flood water levels. To understand the level of isolation and the currently recognised species distribution, the current hydrological situation and the historical paleo-aquifer evolution should also be considered. However in most cases the paleo-hydrology of the Dinarides is very poorly studied and understood. With respect to the above theories, an understanding of the hydrogeology and its hydrological interconnections within the studied aquifers is crucial for an understanding of the phreatic cave genus zoogeography and its species distribution (Fig. 17). As most of the karst aquifers in Hercegovina are represented by subterranean karst conduits, it is difficult to exactly set the watersheds. The subterranean drainage-divides in this map were estimated based on our recent knowledge about the geology, hydrogeology and geomorphology. Each watershed represents a kind of hydrological isolation or barrier which could be important for allopatric evolution of hypogean species (Osikowski 2018). Each drainage basin could be further divided to separate subterranean karst conduits, which could also represent a kind of isolated habitat, especially when the hypogean species cannot be dispersed via water saturated alluvial gravel, surface streams or through hyporheic zones. In contrast, interim or periodical high water levels could lead to temporary groundwater divergence among neighbouring basins and open occasional migration pathways for strictly hypogean species (estimated divergence highlighted by blue arrows). As a typical example of the inter-basin karstwater divergence, we can use the Nikšićko Vrelo in Bileća (Neretva Drainage Basin, tributary of Trebišnjica Basin) which drains water from Nikšičko Polje (Drin Drainage Basin, Tributary of Zeta River), likely from Gornepoljski Vir Estavelle and bringing shells of Plagigeyeria zetatridyma abundant in Nikšićko Polje through $41 \mathrm{~km}$ of karst conduit into the Trebišnjica Drainage Basin.

Each species of Plagigeyeria and Travunijana inhabiting partly isolated subterranean karst conduits, which can be highlighted by the proposed distribution maps (Figs 17-18) as the most probable subterranean distribution range, with the sampling points at the related lowest point at springs (or spring 
caves). The above discussed distribution still represents only a small portion of the Hercegovina karst areas. The range extension of both genera over the so-far uninvestigated karstic territories (as indicated by grey in maps in Figs 18-19) is highly probable.

\section{Conclusions}

In the present study, the genus Plagigeyeria Tomlin, 1930 was split into two morphologically different genera (Plagigeyeria and Travunijana Grego \& Glöer, 2019). The known distribution range of both genera was significantly enlarged within the territory of Hercegovina and adjacent regions, and the number of known taxa in both genera was doubled (from 12 to 24 taxa). The actual understanding of both genera distribution patterns within Hercegovina and its adjacent regions is presented (Figs 18-19). Furthermore, the large number of currently uninvestigated springs and caves in the region suggests a much higher stygobiont Mollusca potential within the phreatic waters of Hercegovina. The stygobiont habitats of Hercegovina are an integral part of the Dinaride karst and the current study is further strengthens its status as a worldwide stygobiont biodiversity hotspot of global importance.

\section{Acknowledgements}

I would like to express my gratitude to Brian Lewarne from the Devon Karst Research Society, Plymouth, UK, for substantial help in understanding the karst hydrology of the studied area, to Vanessa Delnavaz and Daniel Geiger and SBMNH for supporting the study with SEM images, to Peter Glöer, Hetlingen, Germany, for valuable comments during preparation and reviewing of the manuscript, to Dorottya Angyal and Zoltán Péter Erőss from the Natural History Museum, Budapest; Gabriel Jakab, Plešivec; Mário Olšavský and Miroslava Kováčiková, Banská Bystrica, from the Slovak Speleological Society for their active participation on the speleobiological field trips; to Anita Eschner, Nesrine Akkari and Sara Schnedl from the Natural History Museum Vienna, Austria for supporting my photographic activities; to Sigrid Hof and Ronald Janssen from the Senckenberg Museum, Frankfurt for providing photographs of their type material; to Roman Ozimec, Zagreb, for his very useful consultations about the local hydrology. Special thanks to Alexander and Peter Reischütz from Horn, Austria, for providing their material for study and for valuable comments during the review of the manuscript.

\section{References}

Bank R.A.2013. Fauna Europaea: Mollusca. FaunaEuropaea version 2.6.2. https://fauna-eu.org/ [accessed 11 Nov. 2019]

Bank R.A. \& Neubert E. 2017. Checklist of the land and freshwater Gastropoda of Europe. Available from http://www.molluscabase.org/aphia.php?p=sourcedetails\&id=279050 [last update: 16 Jul. 2017; accessed 11 Nov. 2019].

Beran L., Bodon M. \& Cianfanelli S. 2014. Revision of "Hauffenia jadertina" Kuscer 1933, and description of a new species from Pag Island, Croatia (Gastropoda: Hydrobiidae). Journal of Conchology 41 (5): 585-601. https://doi.org/10.1111/jzs. 12159

Beran L., Osikowski A., Hofman S. \& Falniowski A. 2016. Islamia zermanica (Radoman, 1973) (Caenogastropoda: Hydrobiidae): morphological and molecular distinctness. Folia Malacologica 24 (1): 25-30. https://doi.org/10.12657/folmal.024.004

Bilandžija H., Morton B., Podnar M. \& Ćetković H. 2013. Evolutionary history of relict Congeria (Bivalvia: Dreissenidae): unearthing the subterranean biodiversity of the Dinaric Karst. Frontiers in Zoology 10 (5): 1-17. https://doi.org/10.1186/1742-9994-10-5

Bodon M., Manganelli G. \& Giusti F. 1996. A new hydrobiid from subterranean waters of the Timavo River (Friuli-Venetia Julia, NE. Italy) (Gastropoda Prosobranchia: Hydrobiidae). Basteria 60: 27-39. 
Boeters H., Glöer P. \& Pešić V. 2013. Some new freshwater gastropods from Southern Europe (Mollusca: Gastropoda: Trucatelloidea). Folia Malacologica 21 (4): 225-235.

https://doi.org/10.12657/folmal.021.025

Bole J. 1970. Prispevek k poznavanju anatomije in taksonomije podzemelskih hidrobiid (Gastropoda, Prosobranchia). Slovenska Akademija Znanosti in Umetnosti, Razred za Prirodoslovne in Medicinske Vede, Razprave 13 (2): 85-111.

Bole J. \& Velkovrh F. 1986. Mollusca from continental subterranean aquatic habitats. In: Botosaneanu P. (ed.) Stygofauna mundi: 177-206. E.J. Brill, Leiden.

Bonacci O. 2014. Ecohydrology of karst poljes and their vulnerability. In: Sackl P., Durst R., Kotrošan D. \& Stumberger B. (eds) Dinaric Karst Poljes - Floods for Life: p. 25-37. Publisher, Country. Available from https://www.euronatur.org/fileadmin/docs/docs_english/KRASKA_POLJA.pdf [accessed 16 Aug. 2019]

Cindrić K. \& Slapnik R. 2012. Two new subterranean freshwater gastropod species (Gastropoda: Truncatelloidea) from the Rudnica VI Cave in Croatia. Natura Croatica 28 (1): 45-50.

https://doi.org/10.20302/NC.2019.28.4

Glöer P. \& Pešić V.2014. New subterranean freshwater gastropods of Montenegro (Mollusca: Gastropoda: Hydrobiidae), with description of one new genus and two new species. Ecologica Montenegrina 1 (4): 244-248. Available from https://www.biotaxa.org/em/article/view/9181/10937 [accessed 6 Jul. 2020].

Glöer P. \& Grego J. 2015. New subterranean freshwater Molluscs from Bosnia \& Hercegovina (Mollusca: Hydrobiidae). Ecologica Montenegrina 2 (4): 307-314. Available from https://www.biotaxa.org/em/article/view/12697 [accessed 6 Jul. 2020].

Glöer P., Grego J., Erőss Z.P. \& Fehér Z. 2015. New records of subterranean and spring molluscs (Gastropoda: Hydrobiidae) from Montenegro and Albania with the description of five new species. Ecologica Montenegrina 4: 70-82. Available from https://www.biotaxa.org/em/article/view/17424 [accessed 6 Jul. 2020].

Grego J., Glöer P., Erőss Z.P. \& Fehér Z. 2017. Six new subterranean gastropod species from northern Albania and some new records from Albania and Kosovo (Mollusca, Gastropoda, Moitessieriidae and Hydrobiidae). Subterranean Biology 23: 85-107. https://doi.org/10.3897/subtbiol.23.14930

Grego J., Glöer P., Rysiewska A., Hofman S. \& Falniowski A. 2018. A new Montenegrospeum species from south Croatia (Mollusca: Gastropoda: Hydrobiidae). Folia Malacologica 26: 25-34. https://doi.org/10.12657/folmal.026.004

Grego J. \& Glöer P. 2019. A New hydrobiid (Mollusca, Gastropoda, Hydrobiidae) genus of Bosnia and Hercegovina. Ecologica Montenegrina 21: 86-89. https://doi.org/10.37828/em.2019.21.10

Grego J., Glöer P., Falniowski A., Hofman S. \& Osikowski A. 2019. New subterranean freshwater gastropod species from Montenegro (Mollusca, Gastropoda, Moitessieriidae, and Hydrobiidae). Ecologica Montenegrina 20: 71-90. https://doi.org/10.37828/em.2019.20.6

Grego J., Mumladze L., Falniowski A., Osikowski A., Rysiewska A., Palatov D.M. \& Hofman S. in press. Revealing the stygobiotic and crenobiotic molluscan biodiversity hotspot in Caucasus: Part I. The phylogeny of stygobiotic Sadlerianinae Szarowska, 2006 (Mollusca, Gastropoda, Hydrobiidae) from Georgia with descriptions of five new genera and twenty-one new species. ZooKeys.

Hirschfelder H.-J. 2018. Neue Molluskennachweise aus der Ombla-Quelle bei Dubrovnik. Mitteilungen der deutschen malakozoologischen Gesellschaft 96: 33-38. 
Hofman S., Rysiewska A., Osikowski A., Grego J., Sket B., Prevorčnik S. \& Falniowski A. 2018. Phylogenetic relationships of the Balkan Moitessieriidae (Caenogastropoda: Truncatelloidea). Zootaxa 4486 (3): 311-339. https://doi.org/10.11646/zootaxa.4486.3.5

Jaeckel S.H., Klemm W. \& Meise W. 1957. Die Land-und Süsswasser-Mollusken der nördlichen Balkanhalbinsel. Abhandlungen und Berichte des Staatlichen Museums für Tierkunde in Dresden 23: 141-205.

Jaeckel S.G.A. 1967. Gastropoda. In: Illies J. (ed.) Limnofauna Europaea, G. Fischer, Stuttgart, 89-104.

Kuščer L. 1933. Prispevek k poznavanju podzemskih gastropodov Dalmacije in Hercegovine. Prirodoslovna Istraživanja Kraljevine Jugoslavije Izdaje Jugoslavenska Akademija Znanosti I Umjetnosti 18: 59-67.

Kuščer L. 1935. Mollusca. In: Karaman S.(ed.), Die Fauna der unterirdischen Gewässer Jugoslaviens. Verhandlungen der Internationalen Vereinigung für Theoretische und Angewandte. Limnologie, 7:4673.

Milanović P. 2018. Engineering Karstology of Dams and Reservoirs. CRC press - Boca Raton, London/ New York. https://doi.org/10.1201/9780429453403

Osikowski A. 2018. Isolation as a phylogeny-shaping factor: historical geology and cave habitats in the Mediterranean Truncatelloidea Gray, 1840 (Caenogastropoda). Folia Malacologica 25: 213-229. https://doi.org/10.12657/folmal.025.015

Pešić V. \& Glöer P. 2012. A new species of Bythiospeum Bourguignat, 1882 (Hydrobiidae, Gastropoda) from Montenegro. Biologica Nyssana 3 (1): 17-20.

Pešić V. \& Glöer P. 2013a. A new freshwater snail genus (Hydrobiidae, Gastropoda) from Montenegro, with a discussion on gastropod diversity and endemism in Skadar Lake. Zookeys 281: 69-90.

https://doi.org/10.3897/zookeys.281.4409

Pešić V. \& Glöer P. 2013b. Montenegrospeum, a new genus of hydrobiid snail (Gastropoda: Risooidea) from Montenegro. Acta Zoologica Bulgarica 65 (4): 565-566

Radoman P. 1983. Hydrobioidea a superfamily of Prosobranchia (Gastropoda). I. Systematics. Monographs 547, Serbian Academy of Sciences and Arts, Beograd.

Reischütz A., Reischütz N. \& Reischütz P.L. 2013. Beitrag zur Kenntnis der Molluskenfauna Albaniens. Nachrichtenblatt der Ersten Vorarlberger Malakologischen Gesellschaft 20: 61-64.

Reischütz A., Reischütz N. \& Reischütz P.L. 2014. Beitrag zur Kenntnis der Molluskenfauna Albaniens. Nachrichtenblatt der Ersten Vorarlberger Malakologischen Gesellschaft 21: 77-80.

Reischütz A., Steiner-Reischütz N. \& Reischütz P.L. 2016. Beitrag zur Kenntnis der Molluskenfauna Albaniens. Nachrichtenblatt der Ersten Vorarlberger Malakologischen Gesellschaft 23: 81-87.

Rysiewska A., Prevorčnik S., Osikowski A., Hofman S., Beran L. \& Falniowski A. 2017. Phylogenetic relationships in Kerkia and introgression between Hauffenia and Kerkia (Caenogastropoda: Hydrobiidae). Journal of Zoological Systematics and Evolutionary Research 55 (2): 106-117.

https://doi.org/10.1111/jzs.12159

Schütt H. 1959. Zur Höhlenschneckenfauna Montenegros. Archiv für Molluskenkunde 86 (4/6): 185190.

Schütt H. 1960. Neue Höhlenschnecken aus Montenegro. Archiv für Molluskenkunde 89 (4/6): 145-152.

Schütt H. 1961. Die Plagigeyeria-Arten Dalmatiens. Archiv für Molluskenkunde 90: 131-137.

Schütt H. 1963. Vier bemerkenswerte Höhlenschnecken. Archiv für Molluskenkunde 92: 205-213. 
Schütt H. 1972. Ikonographische Darstellung der unterirdisch lebenden Molluskengattung Plagigeyeria Tomlin (Prosobranchia: Hydrobiidae). Archiv für Molluskenkunde 102 (1/3): 113-123.

Schütt H. 2000. Die Höhlenmollusken der Ombla-Quelle. Natura Croatica 9 (3): 203-215.

Sket B. 2012. Diversity patterns in the Dinaric karst. In: White W.B. \& Culver D.C. (eds) Encyclopedia of Caves (Second Edition). Academic Press, New York.

https://doi.org/10.1016/b978-0-12-383832-2.00031-1

Starobogatov Y. I. 1962. Contribution to molluscs from subterranean waters of the Caucasus. Byulleten Moskovskogo Obschchestva Ispytatelei Prirody, Otdel biologicheskiy 67: 42-54.

Stevanović Z., Pekaš Ž., Jolović B., Pambuku A. \& Radojević D. 2014. Classical dinaric karst aquifer an overview of its past and future. In: Kukurić N. et al (eds) The Proceedings conference Karst Without Boundaries, Trebinje. http://www.karst.edu.rs/documents/pdf/Classical\%20Dinaric\%20KA,\%20\%20 plenary\%20by\%20ZS\%20et\%20al.\%20-\%20Extended\%20abstract\%20FINAL.pdf

Stumberger B., Durst R., Kotrošan D. \& Mulaomerović J. 2014. List of karst poljes in Bosnia and Herzegovina. In: Sack1 P., Durst R., Kotrošan D. \& Stumberger B. (eds) Dinaric Karst Poljes - Floods for Life. EuroNatur, Radolfzell.

Tomlin J.R. le B. 1930. Some preoccupied generic names II. Proceedings of the Malacological Society of London 19: 22-24.

Wagner A.J. 1914. Höhlenschnecken aus Süddalmatien und der Herzegovina. Sitzungsberichte der kaiserlich-königlichen Akademie der Wissenschaften (mathematisch-naturwissenschaftliche Klasse) Abteilung I, 123: 33-48.

Wagner A.J. 1928. Studien der Molluskenfauna der Balkanhalbinsel mit besonderer Berücksichtigung Bulgariens and Thraziens, nebst monographisher Bearbeitung einzelner Gruppen. Prace Zoologiczne Polskiego Państvowiego Muzeum Przyrodniczego, 1. XII. 1927, 6: 263-264.

Willmann R. \& Pieper H. 1978. Gastropoda. In: Illies J. (ed.), Limnofauna Europaea: 118-135 (second revised and enlarged edition), Gustav Fischer Verlag, Stuttgart.

Manuscript received: 8 April 2020

Manuscript accepted: 15 May 2020

Published on: 27 July 2020

Topic editor: Rudy Jocqué

Section editor: Thierry Backeljau

Desk editor: Marianne Salaün

Printed versions of all papers are also deposited in the libraries of the institutes that are members of the EJT consortium: Muséum national d'Histoire naturelle, Paris, France; Botanic Garden Meise, Belgium; Royal Museum for Central Africa, Tervuren, Belgium; Royal Belgian Institute of Natural Sciences, Brussels, Belgium; Natural History Museum of Denmark, Copenhagen, Denmark; Naturalis Biodiversity Center, Leiden, the Netherlands; Museo Nacional de Ciencias Naturales-CSIC, Madrid, Spain; Real Jardín Botánico de Madrid CSIC, Spain; Zoological Research Museum Alexander Koenig, Bonn, Germany; National Museum, Prague, Czech Republic. 